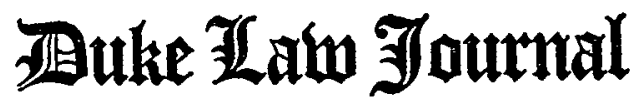

\begin{tabular}{lll}
\hline VOLUMe 1974 & SEPTEMBER & NUMBER 4 \\
\hline
\end{tabular}

\section{ESTATE PLANNING FOR JOINT TENANCIES}

\author{
REgis W. CAMPFIELD*
}

I. INTRODUCTION

\section{OUTLINE}

II. Statement of the Problem
A. Role of Inflation
B. Marital Dednction
C. Lifetime Gifts
D. The A and B Trust Arrangement
E. The Human Element

III. Co-Ownership: State Law and the Federal Estate and Gift Taxes

IV. Termination of Joint Tenancy During Life

A. Objective: Estate Equalization

B. Obstacle: Federal Gift Tax Considerations
(1) Joint Tenancy with Right of Survivorship
(2) Tenancy by the Entirety
(3) Joint Bank Accounts
(4) Section 2515 Property
(5) Illustration: Real or Personal Property Held as Tenants by the Entirety
(6) Illustration: Real Property Held as Joint Tenants with Right of Survivorship
(7) Summary

C. Non-Tax Considerations

V. Termination of Joint Tenancy in Contemplation of Death

A. Estate Planning Possibilities

(1) Joint Tenancy with Right of Survivorship

(2) Tenancy by the Entirety

(3) Joint Bank Accounts

B. Policy Considerations

C. Some Speculative Suggestions: Tenancies by the Entirety

(1) Criticism of Borner

(2) Transfens for Adequate and Full Consideration

(3) Actuarial Valuation of Transfers in Contemplation of Death

* B.B.A. (Accounting) 1963, University of Notre Dame; LL.B. 1966, University of Virginia; Member of Indiana, Ohio, and Virginia Bars; Assistant Professor of Law, Notre Dame Law School, 1970-74. 
(4) Section 2515 Property

(5) Conclusion

VI. JoInt Tenancies AND TRUSTS

A. The Irrevocable Trurt

(1) Estate Tax Consequences

(2) Gift Tax Consequences

(3) Conclusion

B. The Revocable Trust

(1) Estate Tax Consequences

(2) Gift Tax Consequences

(3) Conclusion

C. The Partially Irrevocable Trust

(1) Generally

(2) Illustration: Problems in Application

(3) Lewis v. United States

(4) Revenue Ruling 7I-5I

(5) Summary

VII. Postmortem Planning

VIII. Conclusion

IX. EpILOGue

\section{INTRODUCTION}

Joint ownership of real and personal property by husband and wife in a common law jurisdiction is so generally accepted that to hold property in the name of only one spouse is the exception rather than the rule. This Article will attempt to outline the alternatives available in planning for such jointly held property. It will consider the commonly used A and B trust device; the need to terminate all joint ownership arrangements; and the appeal of terminating such arrangements in contemplation of death. Special emphasis will be placed on the tax planning potential of estate equalization. Also to be considered will be the use of trusts where property management is important. Finally, this Article will propose the use of a partially irrevocable trust where taxpayers are reluctant to terminate their joint ownership arrangements during their joint lifetimes. Special emphasis will be placed on the inconsistency in the estate tax treatment of jointly held property which is transferred in contemplation of death and that which is retained in joint ownership until death.

This Article should make it apparent that taxpayers whose estates will be subject to federal estate tax should be discouraged from holding property as joint tenants because of the profoundly difficult estate planning that it makes necessary. Unfortunately, however, taxpayers often postpone estate planning until late in life when their estates already consist largely of property held as joint tenants with right of survivorship or as tenants by the entirety. 
The discussion throughout this Article will be limited to cases where the joint owners are husband and wife.

\section{Statement of the Problem}

\section{A. Role of Inflation}

For generations married persons in common law jurisdictions have been counseled by bank personnel and real estate salespeople ${ }^{1}$ to take title to real and personal property as joint tenants with rights of survivorship. The principal reason given is that the joint tenancy relationship ${ }^{2}$ will facilitate transfer to the survivor upon the death of the first joint tenant to die.

This feature and the other so-called advantages of joint tenancy ${ }^{3}$ concededly have appeal in the estate not burdened by death taxation.

1. Lawyers have, on occasion, given the same advice where it is clear that the client will never have an estate subject to the federal estate tax. See T. SHAFFER, THE Planning and Drafting of Wills and Trusts 62 (1972). The problem is one of predictability. When is it clear that the client will never have any death tax problems? The rule may be better expressed in these terms: "[T]he holding of property as joint tenants with right of survivorship should be the deliberate exception rather than the general rule ..." Worthy, Problems of Jointly Owned Property, 22 TAX LAWXER 601 (1969).

\section{ARTICLE:}

HEREAFTER THE FOLIOWING CITATIONS WILL BE USED IN THIS

A. Casner, Estate Planning (3d ed. 1961) [hereinafter cited as A. Casner];

AMERICAN LAW Op Property (A.J. Casner ed. 1952) [hereinafter cited as AM. LAW PROPERTY];

C. Lowndes \& R. Kramer, Federal Estate and Gift Taxes (2d ed. 1962) [hereinafter cited as C. LowNDEs \& $R$. KRAMER];

J. Mertens, The LaW of Federal Gift and Estate Taxation (1959) [hereinafter cited as J. MERTENS];

C. Moymthan, Iaw of Real Property (1962) [hereinafter cited as C. Moyninan];

R. Powell \& P. Rohan, The LaW of Real Property (1973) [hereinafter cited as R. POWELl \& P. ROHAN].

2. When the terms "joint tenancy," "jointly held property" or "joint tenancy with right of survivorship" are used in this article, the reference includes tenancy by the entirety except when the context otherwise requires. ing:

3. The advantages of joint tenancy with right of survivorship include the follow-

a. Jointly held property oftentimes enjoys preferential treatment for state death tax purposes. State statutes are of two kinds:

(1) Those which exempt from state death taxation one-half of all jointly held property where the joint tenants are husband and wife. See, e.g., Онто Rev. Code ANN. \$5731.10 (1973). This is an advantage where the first spouse to die provided all the consideration for the property. It is hardly an advantage where the non-contributing spouse dies first. Apparently these state rules were designed to avoid the proof problems presented survivors under federal law when jointly held property is involved. The federal estate tax requires all of the jointly held property to be in- 
But in an increasing number of cases, prospective decedents with large amounts of jointly held property are going to have to face the prospect

cluded in the estate of the first to die except to the extent the survivor can prove contribution. See INT. Rev. CoDE OF 1954, \& 2040.

(2) Those which exempt from state death taxation all real property held as tenants by the entirety. See, e.g., IND. STat. ANN. § 6-4-1-1 (Codo ed. 1972). In such cases all other jointly held property will be included in the estate of the first to die except to the extent the survivor can prove contribution. Id. These statutes exempting tenancy by the entirety real property from state death taxation may be reason enough for holding such property as tenants by the entirety in those cases where the estate will not be subject to federal estate taxation. The availability of this exemption has initial appeal even in cases where there will be liability for federal estate tax. However, for reasons which will bo outlined in this Article, such holdings should probably be limited to the taxpayers' residential preanises, and then, only after carefully considering both tax and non-tax considerations. Perhaps it is appropriate to note that state death tax rates are hardly confiscatory, ranging, as they frequently do, from a low of one percent to a high of twenty percent (on property over one million dollars in valne). See, e.g., id. § 6-4-1-2.

b. Jointly held property is free from the claims of creditors of either spouse. For example, in some states if the property is held by the spouses as tenants by the entirety the property can be removed from the reach of the separate creditors of the husband and wife and from the reach of prior spouses. See Lewis v. United States, 485 F.2d 606 (Ct. Cl. 1973) (tenancy by entirety used "to thwart significant third-party claims." Id. at 612). Nevertheless, this socalled advantage has appeal only in those cases where a decedent's probate property is inadequate to satisfy his creditor's claims. Even where claims exceed probate property, this incident of joint ownership will offer little real protection. For example, it is an unusual case for a lender to make a loan to one spouse without securing the other spouse's personal guaranty. And if the joimt tenants are not married to one another, the existence of the joint property will be disclosed on the borrower's fimancial data summary provided the lender, and the lender no doubt will take steps to make this collateral available to secure the debt.

c. Joint property expresses the idea of partnership in a marriage and reinforces family security and harmony. This kind of argument is hard to combat, and it cannot be disunissed as trivial.

The following advantages have appeal, but a revocable trust will accomplish the same results (where the property is not jointly held) with greater predictability as to tax consequences and with significant non-tax planning opportunities.

d. Joint property reduces administration costs. This is true in the sense that the estate's administrator cannot include jointly held proporty in the base ho uses in computing his fee. It is, however, included in computing the attornoy's fee, albeit at a lower percentage.

e. Joint property avoids probate delays. Ordinarily probate property cannot be distributed for at least six months after administration is cominenced. See, e.g., OHTo Rev. Code ANN. § 2113.53 (Supp. 1973). A substantial portion, but generally not all, of the jointly held property is available to the survivor immediately after death. See, e.g., id. $\$ 5731.39(\mathrm{~B})$.

f. Joint property avoids publicity. It is common in sone communities for the newspapers to regularly publish the probate contents of a decedent's estate as 
of their estates being subjected to the federal estate tax. ${ }^{4}$ This is an unfortunate result because in most cases it is only persons of modest means who hold a substantial portion of their property in joint tenancy form. In earlier times, death tax planning was unnecessary for the person of modest means because the $\$ 60,000$ federal estate tax exemption ${ }^{5}$ spared him federal death taxation. ${ }^{6}$ Unfortunately, the federal death tax exemption has not been adjusted to reflect the effects of inflation on property values. ${ }^{7}$ Consequently, a modest estate in terns

reported to the court having jurisdiction over estates. The joint property will only appear on tax returns which are, theoretically, confidential.

g. Joint property is convenient. It is alleged that either party can deal with jointly held property. That is not the case. If the property is held as tenants by the entirety, the consent of both spouses is required for transfer. If held as joint tenants with right of survivorship, either spouse may dispose of his fractional interest (in most cases). See note 43 infra and accompanying text.

h. Joint property avoids fragmentations of ownership. Intestate distribution of a decedent's property usually fragments ownership. The survivorship feature of the joint tenancy avoids that result, but au ordinary will can be drafted which will have the same effect.

See generally Worthy, supra note 1, at 606; Research Institute of America, Inc., Should You Own Property Jointly? appearing as a Special Study in TAX CoordINATOR, June 21, 1973, 1, 1-2; Effland, Estate Planning: Co-Ownership, 1958 Wrs. L. Rev. $507,539-40$.

4. See INT. Rev. Code of 1954, \$ 2040.

5. See id. $\$ 2052$. The exemption has not been changed since 1942 .

6. This Article will not concern itself with state gift or death taxation. See note 3 supra for examples of state laws concerning taxation of jointly held property.

7. The data available is "old" and clearly does not reflect the current growth in property values due to inflation. But even that data suggests the magnitude of the increase in property values. The number of persons dying each year in the United States rose five percent between 1965 and 1971. Information Please Almanac 709 (27th ed. 1973). During that same period, the number of estate tax returns filed increased approximately fifty-four percent. U.S. TREASURY DEP'T ANNUAL REPORT OF THE COMM'R OF INT. REV. 14 (Publication No. 55) (1966, 1971, respectively). Over a slightly shorter period, 1966-1970, the total of all taxable estates increased approximately twenty-seven percent. U.S. DEP'T OF THE TREASURY, STATISTICS OF INCOME FOR 1970: Estate TAX 2. Even more siguificant is the fact that for the fiscal year ended June 30,1972, the combined revenue collections for estate and gift taxes increased fortyfive percent over the prior fiscal year. U.S. TREASURY DEP'T, ANNUAL REPORT OF THE COMM'R OF INT. Rev. 74 (Publication No. 55, 1972).

Perhaps, it should be noted, too, that there is some disagreennent about whether the federal estate tax exemption is pegged too low. See Bittker, Federal Estate Tax Reform: Exemptions and Rates, 57 A.B.A.J. 236 (1971). Professor Bittker argues that there is little correlation between the present $\$ 60,000$ exemption and the needs of the decedent's family, id. at 237; and the only justification for a flat exemption is to keep small estates "out of the federal pipeline," id. at 239. Given the revenue needs of an expanded governinental operation, he suggests the emphasis should be placed on developing a basic exemption, perhaps $\$ 25,000$, coupled with an unlimited marital deduction and a dependency exeinption to avoid bardship. $I d$. While Bittker's argument is an appealing one, there seems to be congressional sympathy for the plight of the taxpayer with a modest estate. Congressman Mills, current chairman of the House 
of real purchasing power is a substantial estate under the federal death tax standard of $\$ 60,000$, and practicing attorneys writing wills for the old "nonestate client" will encounter special probleins because of jointly held property.

\section{B. Marital Deduction}

The need for tax planning in so-called "modest" estates can be easily illustrated. For example, a taxpayer with an adjusted gross estate $^{9}$ of $\$ 200,000$, all of which passes to soineone other than his surviving spouse, will incur a federal estate tax liability of $\$ 32,700 .^{10}$

\section{Committee on Ways and Means, has stated:}

We are not going to wind up with a tax system that meets the purist standards of academicians but shuts off the wellsprings of economic progresspersonal and business savings .... [W]e are not going to have the Government confiscate half or more of the estates people manage to build for their families. 119 Cong. REC. H 4116 (daily ed. May 30, 1973).

His views have been interpreted as follows:

[Mills] wants to see more protection for medium-sized estates. The estate taxes on farms and sinall businesses often force heirs to sell out in order to raise the tax payment. And inflation has greatly eroded the value of the

$\$ 60,000$ exemption ... Bus. WEEK, April 13, 1974, at 25.

8. This very descriptive phrase was coined by Thomas $L$. Shaffer in an extremely lucid article first prepared in 1965 to describe the client for whom tax planning was not important. T. SHAFFER, supra note 1, at 59.

9. "Adjusted gross estate" has been defined by Congress to be the difference between a decedent's gross estate for federal estate tax purposes and the deductions allowed his estate for expenses of administration, his debts, taxes assessed as a consequence of his death, funeral expenses, and casualty losses incurred during the course of settling the estate. See INT. REv. CODE OF 1954, \& 2056(c)(2)(A). Its only function for purposes of the federal estate tax is to serve as a basis for determining the maximum marital deduction allowed a decedent's estate for property passing to his spouse. The term is employed here for convenience of reference.

10. The following organizational scheme has been employed throughout this Article in making the indicated federal estate tax computations. All references below are to the Internal Revenue Code of 1954.

Decedent's Gross Estate ( $\$ \$ 2031-42)$

Less: Expenses of administration, decedent's $\$ x \times x \times x$

indebtedness and taxes ( $(2053) — \mathrm{xxx}$
Casualty losses incurred during
administration ( $\$ 2054)$

Adjusted Gross Estate ( $\$ 2056$ (c)(2))

Less: Exemption ( $\$ 2052)$

Charitable Deduction (\$2055)

Marital Deduction (maximum: $50 \%$ of

Taxable Estate ( $\$ 2051$ ) adjusted gross estate) ( $\$ 2056)$

Rate of $\operatorname{tax}$ (applied against taxable estate) $(\$ 2001)$
Tax liability before credits

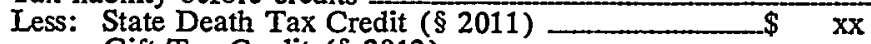

Gift Tax Credit (\$ 2012) - - $\mathrm{xx}$

Credit for Tax on Prior Transfers (\$ 2013)—

Credit for Foreign Death Taxes $(\$ 2014) \_\quad$ XX

Credit for Death Tax on Remainders $(\$ 2015) \ldots \quad$ Xx

Federal Estate Tax Liability 
On the other hand, if the taxpayer's spouse survives him and she takes all of his property, the marital deduction ${ }^{11}$ available with respect to fifty percent of his adjusted gross estate will cause his federal estate tax bill to be reduced to $\$ 4,800$. However, at the death of the surviving spouse, all of the property which she owns at her death will be subjected to the federal estate tax. In this example, if the wife had taken all of her husband's property at his death and had not invaded principal-a common occurrence-her federal estate tax hability (assuming she had no property of her own) would be $\$ 32,700$, which, when added to the tax liability of $\$ 4,800$ at her husband's death, would result in a total transfer tax liability of $\$ 37,500 .{ }^{12}$ Thus, while the availability of the marital deduction is a distinct advantage to taxpayers, in many cases it merely serves to postpone the tax until the death of the second spouse.

\section{Lifetime Gifts}

In cases where property included in the estate of the first spouse to die will also be included in the survivor's gross estate at her subsequent death, it would be easy to argue that the surviving spouse should divest herself of a substantial portion of her total property by lifetime transfers after her husband's death. She could, for example,

11. Estates are allowed a deduction in computing federal estate tax liability for property passing to the decedent's surviving spouse. See INT. Rev. Code of 1954, \& 2056. The purpose of the marital deduction is to place residents of common law jurisdictions on approximately the same footing as residents of community property jurisdictious for purposes of the federal estate tax. See C. Lowndes \& R. KRAMER \$ 17.1.

When a married person died in a community property state ordinarily only half of the community property was taxed to his estate, even though it had all been accumulated due to his individual efforts. This discriminated against the residents of common law states, since the entire estate which a married man accumulated in a common law state was taxed at his death. Id. at 369 (footnote omitted).

The statute is extremely complex and has generated volunies of commentary as well as an enormous amount of litigation resulting from attempts by taxpayers to take advantage of its provisions.

12. Double taxation of half of a decedent's property is not uncommon. The Treasury Department reports, for example, that decedents with adjusted gross estates under $\$ 300,000$ made outright bequests of seventy-one percent of their estates to their snrviving spouses. Of this seventy-one percent, only forty-one percent qualified for the marital deduction, indicating that thirty percent of the property transferred will be taxed twice. Tax Reform Studies and Proposals, U.S. Treasury Dep'T, House Comm. on Ways and Means and Senate Comm. on Finance, Joint Publication 91st Cong., 1st Sess., pt. 3, at 360 (Comm. Print).

In an effort to preveut the federal estate tax from beconing too oppressive to the estate of a decedent who acquired property from a prior decedent who died within 10 years of the second decedent's death, the estate of the second decedent enjoys a credit for the estate tax paid by the estate of the prior decedent upon property transferred to the secoud decedent. See INT. Rev. CODE OF 1954, § 2013. 
inake gifts of that property which was included in her husband's estate and which escaped taxation in her husband's estate because of the marital deduction. Such transfers would be subject to the federal gift $\operatorname{tax}^{13}$ but the $\$ 30,000$ federal gift tax exemption ${ }^{14}$ and the $\$ 3,000$ per donee per annum exclusion ${ }^{15}$ would be available to reduce the ultimate tax liability. Moreover, the federal gift tax rates are only seventy-five percent of the federal estate tax rates. $^{16}$ Thus, in transferring $\$ 100,000$ during her lifetime, for example, (assuming it is divided equally between two donees and assuming she had inade no prior gifts) the surviving spouse would incur gift tax in the amount of $\$ 7,965^{17}$ and, at her death, her federal estate tax bill would be $\$ 4,800$. Thus the total federal transfer tax cost to husband and wife would be $\$ 17,565(\$ 7,965+\$ 4,800+\$ 4,800)$ which would represent a substantial saving over the $\$ 37,500$ which would be payable if she does not make any lifetime transfers.

The counter arguinent is that the surviving spouse is accustorned to the standard of living made possible by the $\$ 200,000$ available to the family unit during her husband's lifetime and therefore cannot afford the luxury of transferring a substantial portion of the fund after her husband's death. The obvious response is to suggest that the wife

13. Treas. Reg. § 25.2511-1(c) (1954).

14. INT. REv. CODE OF 1954, § 2521.

15. Id. $\$ 2503(\mathrm{~b})$.

16. Compare INr. Rev. CODE of 1954, \& 2001 with INT. Rev. CODE OF 1954, § 2502(a).

17. The following organization scheme has been employed throughout this Article in making the indicated federal gift tax computations. All references below are to the Internal Revenue Code of 1954. Transfers of property $(\$ \S 2501,2511)$

Less:

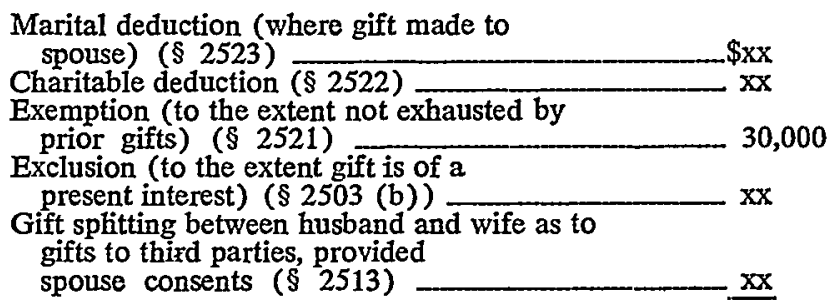

Taxable gifts this period ( $\$ 2503$ (a))

Plus:

Taxable gifts in prior periods Aggregate lifetime gifts

Rate of tax (applied against aggregate

lifetime gifts) $(\$ 2502(a))-2 x \%$

Total lifetime gift tax liability

Less: Gift tax paid in prior periods

Federal gift tax liability this period ( $\$ 2502(a)$ ) 
could supplement the income from the property that she did not transfer by consuming a part of the principal. This would, in fact, be quite desirable because the principal that she consumed would obviously escape federal estate taxation at her death. Unfortunately, not many surviving spouses will agree to invade principal. They reason-and perhaps properly-that an intact principal is protection against living too long and becoming a ward of the state. Similar protection would be available if the surviving spouse purchased an annuity for herself for life, ${ }^{18}$ but an annuity suffers from lack of flexibility.

Whenever lifetime transfers are suggested, the client will generally inquire about retaining the income from the transferred property. This can be done, but only at the expense of having all the property in which the transferor has an imcoine interest for life included in the transferor's estate for federal estate tax purposes. ${ }^{19}$

\section{The $A$ and $B$ Trust Arrangement}

As life insurance has become an increasingly larger part of people's assets, estate planning advice has come to be expressed primarily in terms of a pour-over will and a revocable life insurance marital deduction trust. ${ }^{20}$ The plan, typically, will call for the insured, who for purposes of illustration is the husband, to establish a trust with a local financial institution and assign all of his life insurance to the trust. Under the terms of the trust the insured husband will retain all the imcidents of ownerslip in the policies as well as the right to revoke the trust at any time. The trustee, for his part, will agree that if the trust lias not been revoked before the husband's death, the trustee will collect the proceeds of the insurance and hold those proceeds pursuant to the terms of the trust. The plan will also call for the husband to execute a will directing that, at his death, all of his probate property be delivered to the trustee.

At the husband's death, then, the trustee will collect both the life insurance proceeds and the probate property. The trust agreeinent will probably then provide that the trust corpus be split into two funds,

18. A bfe annuity has great appeal in that nothing will be included in the annuitant's estate at death for federal estate tax purposes and the annuitant has protection against living too long. See INT. Rev. CODE OF 1954, \& 2039(a).

19. See id. $\$ 2036(a)(1)$. But see notes 274-75 infra and accompanying text.

20. All the advantages of the pour-over will-revocable trust scheme are available in a testamentary trust. In many jurisdictions, however, the testamentary trust suffers the disadvantage of continuous court supervision. Compare IND. STAT. ANN. $\$ 30-$ 4-6-4 (Code ed. 1972) with OHIo Rev. Code ANN. $\$ \S 2104.24(D),(M), 2109.02$ (1968). For that reason so-called court trusts are more expensive and more cumbersoine to administer than inter vivos trusts. See A. CASNER 147. 
commonly known as Fund $\mathrm{A}$ and Fund B. The trustee will be directed to allocate to Fund $A$ an amount equal to the maximum marital deduction reduced by any nonprobate property passing directly to the surviving spouse which qualifies for the marital deduction. ${ }^{21}$ Fund A will either be (1) distributed directly to the wife, or (2) retaimed in trust for the wife on terms which allow it to qualify for the marital deduction for federal estate tax purposes. ${ }^{22}$ The balance of the trust property-Fund B-will contimue to be held in trust for the wife's lifetime, and at her death the corpus will be distributed to the husband's then living lineal descendants per stirpes. ${ }^{23}$

The practical effect of this plan on the hypothetical $\$ 200,000$ estate described above is quite simple if the husband dies first. It calls for half of the husband's estate to be taxed at his death, and the

21. For alternative allocation provisions having similar effect, see the references included in note 27 infra.

22. In cases in which the husband wants his wife to have Fund $A$ outright and free of trust, it is customary to include such a provision in his will. It will direct the husband's executor to distribute an amount equal to the maximum marital deduction (reduced by any non-probate property passing to the spouse) directly to the wife and pour-over the balance of the probate property to a trust with only Fund B provisions. This procedure prevents probate property, ultimately destined for the wife, from passing through the trust where the trustee may impose a distribution fee. See A. CASNER 308 (Supp. 1973). In some cases, however, the temptation to seek maximization of the marital deduction and avoidance of the "second tax" will cause lawyers to have the probate property pour-over into the trust where the trustee can take account of and effect the distribution of life insurance in allocating between Fund $A$ and Fund B. While it would be possible for the insurance company to pay the life insurance directly to the husband's estate (in which case the will could include appropriate allocation provisions), it would inean that the proceeds of life insurance would be included in the husband's estate for state death tax purposes. See, e.g., OHro Rev. CODE ANN. \$ 5731.12(A) (1973). If such proceeds are paid to a named beneficiary-a trustee of a revocable life insurance trust qualifies-those proceeds will be free of such taxation. See id.

When Fund $A$, the marital deduction fund, is to be held in trust, special care must be taken to qualify the trust under INT. REv. CoDe of 1954, § 2056(b) (5).

23. Most such trusts provide that Fund $B$ will be distributed per stirpes to those limeal descendants of the settlor (the husband) who are living at the time Fund $B$ is distributed. A per stirpes distribution means, for example, that if a child of the settlor dies before distribution, the child's children will take the share the child would have received. This device provides for changes in potential distributees between the date the trust is created and the date of the distribution. By so doing it avoids having grandchildren disinherited because their parent, the settlor's child, did not survive until distribution of Fund B.

An alternative form would have the wife designate the ultimate takers of Fund $B$ by giving her a special power of appointment exercisable in favor of a limited class of persons, probably lineal descendants of the settlor. So long as the power is not exercisable in favor of the wife or her estate, her creditors or creditors of her cstate, the property subject to the power will not be included in her gross estate for federal estate tax purposes. See INT. REv. Code of 1954, § 2041. See note 70 infra. 
other half to be taxed to his wife at her death. ${ }^{24}$ Their combined federal estate tax liability will be reduced to $\$ 9,600$, a substantial saving over the $\$ 37,500$ tax liability which would have resulted had the wife received outright all of the property included in her husband's estate and died without consuming any of the principal. The tax savings appeal of the A and B trust arrangement is customarily explained in terins of having avoided the second tax on half the property.

More importantly, the A and B trust arrangeinent allows the wife to have an income interest in both the $A$ and $B$ funds, yet exclude the $\mathrm{B}$ fund from her gross estate. That would not have been possible had the wife received outright all of the property included in her husband's estate and then attempted to reduce her federal estate tax burden by making gifts of her property during the remainder of her life. ${ }^{25}$

Unfortunately, some very real problems are presented when the A and $B$ trust arrangement is sought to be applied to taxpayers whose estates consist largely of jointly held property. The A and B trust arrangement is designed to minimize the tax cost of transferring property from one generation to the next. Its efficiency is dependent, however, on all of the property in the settlor's taxable estate being subject to its terms. Jointly held property, on the other hand, will vest in the surviving spouse by operation of law and will not be subject to the dispositive provisions of the $A$ and $B$ trust arrangement. For that reason the tax savings of the $A$ and $B$ trust, which will result when the spouse with the taxable estate dies first, will be progressively reduced by the amount by which the jointly held property included in the estate of the first spouse to die exceeds 50 percent of that spouse's adjusted gross estate. ${ }^{26}$

This principle can easily be illustrated. Assume that $\mathrm{H}$ has an $\mathrm{A}$ and $\mathrm{B}$ trust arrangement; a $\$ 200,000$ adjusted gross estate, $\$ 150,000$

24. This analysis assumes that the wife will survive her husband and that her only property for federal estate tax pnrposes is that received from her husband at his death. In this case if the wife dies first, there can be no planning for the marital deduction. For this reason it is often suggested that the optimum estate plan would call for husband and wife to divide their property equally between them so that the order of their deaths then becomes unimportant. However, it is not the purpose of this Article to consider this proposal except as it relates to jointly held property. For such a discussion, refer to the text accompanying notes 64-70 infra.

If, in this example, the wife dies first, the estate tax liability at the death of the husband would be $\$ 32,700$ if the estate has not been diminished.

25. See note 19 supra, notes $64-70,274$ infra and accompanying text.

26. Amounts in excess of fifty percent of the decedent's adjusted gross estate which pass to the surviving spouse do not qnalify for the marital deduction and therefore will be taxed at the death of the first spouse to die and again at the death of the second to die unless the survivor of the two consumes or disposes of this property during her lifetime. See INT. REv. CODE OF 1954, § 2056. 
of which is jointly held with $\mathrm{W}$; that $\mathrm{H}$ provided all the consideration for the acquisition of the jointly held property; that $\mathrm{W}$ has no property of her own; and that $\mathrm{H}$ dies first. The jointly held property will vest directly in his surviving spouse and will not be subject to the terms of his pour-over will-revocable trust arrangement. The jointly held property will be taken into account, in all probability, for tax planning purposes, by a formula marital deduction clause ${ }^{27}$ which provides that the amount of property allocated to Fund $\mathrm{A}$ will equal the maximum marital deduction allowed the decedent's estate reduced by the nonprobate property, e.g. jointly held property, passing outside the will to the surviving spouse which qualifies for the marital deduction. In this example nothing will be allocated to Fund $A, \$ 50,000$ to Fund $B$, and the surviving spouse will own $\$ 150,000$ of jointly held property in fee simple absolute. Nonetheless, the federal estate tax at H's death will only be $\$ 4,800$, but at W's death, her estate will include the $\$ 150,000$ jointly held property which vested in her at her husband's death (unless she consumes it or disposes of it). Her estate's death tax bill will be $\$ 17,900$, or a total transfer tax bill for husband and wife of $\$ 22,700$. This result is the necessary consequence of the fact that half the estate is taxed at the husband's death and that threefourths will be taxed at the wife's death. In other words, one-fourth of the husband's estate will be taxed twice!

Thus, effective tax planning is impossible where jointly held property inakes up inore than 50 percent of a taxpayer's estate. The traditional tax planning devices will simply not reach the jomtly held property because the survivorship feature of the joint tenancy relationship causes property which would otherwise be sheltered in the B trust to vest directly in the surviving spouse. As a consequence, federal tax liability cannot be minimized.

\section{E. The Human Element}

There are a number of possible solutions. They range from a postmortem argument that the jointly held property was not a true joint tenancy ${ }^{28}$ to a lifetime decision by the taxpayers to split their jointly held property between themselves and to hold it as tenants in common. ${ }^{29}$ For many taxpayers, however, the only realistic

27. For a detailed outline of the different kinds of formula and non-formula marital deduction clauses, see Edwards, Marital Deduction Formulae-A Planner's Guide, 1967 DUKe L.J. 254; Polasky, Marital Deduction Formula Clauses in Estate PlanningEstate and Income Tax Considerations, 63 Мich. L. Rev. 809 (1965). See generally A. CASNER 783-84; C. LOWNDES \& R. KRAMER \$\$ 42.1-42.10.

28. See notes 306-11 infra and accompanying text.

29. See note 80 infra. 
solution for minimizing the tax bite is to devise a scheme which is operative only after the death of one spouse. ${ }^{30}$ The author has advised a number of taxpayers whose estates consist largely of jointly held property. Such taxpayers will often as not be neither middle-management nor middle-aged. ${ }^{31}$ They will probably be over 60 , approaching retirement, and, at the urging of their spouses, will be seeking a review of the simple wills they executed fifteen to twenty years ago. They probably will not have more than $\$ 50,000-\$ 60,000$ of life insurance. What they will have is a house without a mortgage, two automobiles, $\$ 5,000$ at most in stocks and bonds, cash, and perhaps the wife will work ${ }^{32}$-assets of anywhere from $\$ 50,000$ to $\$ 200,000$. Most importantly, everything will be jointly held. ${ }^{33}$ Beginning, prob-

30. See text accompanying notes 236-42 supra.

31. Taxpayers in middle age have not escaped the crushing financial burdens imposed by acquisitiveness and the educational needs of their children. Their estates consist largely of substantial amounts of life insurance. See Corcoran, The Contingent Insurance Trust-A Hidden Bonanza for Minor Children, 55 ILL. B.J. 596 (1967).

Middle management seems to go with middle age and those whose estates consist Iargely of jointly held property are probably not middle aged. However, it would seem that many older taxpayers whose careers long ago plateaued could be described as middle management.

32. Many of the principles outlined in this Article apply to farmers, many of whom hold title to their increasingly valuable farm lands as tenants by the entirety. However, as a general proposition, estate planning for farmers is a specialty of its own and reference must be had to other materials written with farmers specifically in mind. See, e.g., A. CASNER 1001-06; Kelley, The Utility of the Close Corporation in Estate Planning \& Administration, 49 NOTRE DAME LAWXER 334 (1973).

33. While much of the discussion in this Article has general application, the Article itself is directed to planning for the estate which is made up largely of jointly held property. It is believed that there are large numbers of taxpayers who hold substantially all their property as joint tenants with right of survivorship and as tenants by the entirety and that, in future years, the estates of many of these taxpayers will incur federal estate tax liability. Unfortunately there is little or no information available as to the numbers of such persons. This is probably attributable to the fact that many persons who would be included in this group are still living. See note 7 supra. Inflation at current levels is a fairly recent phenomenon. Given this fact, the limited data which is available is "old." For example, the most recent study available examined 659 estates obtained from the Cuyahoga County (Cleveland), Ohio Probate Court docket. M. Sussman, J. Cates \& D. Smrth, The Fammy \& Interitance 45 (1970). This represented a five percent random sample of estates closed between November 9,1964 and August 8, 1965. Id. Obviously, the decedents whose estate proceedings were studied had died, at the latest, in the early part of 1964. Interestingly, that study disclosed that only thirty-two of the 659 estates examined incurred federal estate tax liability. $I d$. at 73 n.20. The mean gross of all testate estates was $\$ 41,218$ but the median was only $\$ 15,000$. Id.

The data gathered in the Cleveland study suggests that only a small percentage of decedents' estates incur federal estate tax liability. That would appear to be a valid conclusion. There were approximately 1.9 million deaths each year in the United States during the period 1965-71. Information Please Almanac supra note 7, at 709. During this same period the number of estate tax returns filed ranged from a low of 
ably, in the depression these taxpayers and their spouses have been conditioned to think "ours" and now, in their later years, it is difficult to rethink ownership in terms of "his" and "hers." 34 While a lifetime sphit of jointly held property into a tenancy in common would possibly enable the former joint tenants to mentally characterize the property as "ours," the important survivorship feature would be gone.

\section{Co-ownership: State LaW AND the FEderal Estate and Gift TaXes}

There are three forms of co-ownership: tenancy in common,

94,000 in 1965 to a high of 149,000 in 1971. U.S. TREASURY DEP'T, ANNUAL REPORT of THE COMM'R OF INT. Rev. 14 (Publication No. 55) (1966, 1971 respectively). Further support is given this conclusion by the announcement of the Urban Institute that there are only five million taxpayers with a net worth of $\$ 60,000$ in the United States. Wall Street Journal, Feb. 20, 1974, at 1, col. 5 (Midwest ed.). This conclusion was based on extrapolating data from 1969 estate tax returns. Whether these numbers reflect life insurance was not clear from the report. It would seem that they do not. For example, it was reported that $\$ 1.4$ trillion of life insurance was in force in the United States and that the average family with life insurance had $\$ 24,800$ of protection. R. KeLSEY, HANDBOOK OF LIFE INSURANCE 11 (1966).

Nonetheless it appears that joint tenancies and tenancies by the entirety are extremely popular forms of property ownership. See Hines, Real Property Joint Tenancies: Law, Fact and Fancy, 51 Iowa L. Rev. 582 (1966). Professor Hines' study concluded that the popularity of joint ownership is a fairly recent phenomenon. It began to develop in the 1930's as property was sold out of foreclosure, and enjoyed a dramatic increase during and after World War II, probably as the result of the wartime psychological fears of death and the popularity of War Bonds which had a built-in survivorship feature. Id. at 586-90. (It was recently estimated that seventy-five percent of the 500 billion dollars worth of Series E United States Savings Bonds outstanding are registered in co-ownership form. United States v. Chandler, 410 U.S. 257, 262 n.4 (1973).) By the 1960's joint ownership had become a part of the conventional wisdom and in 1964 Professor Hines reported that fifty-two percent of Iowa land transfers created joint tenancies. Hines, supra, at 587.

The continuing popularity of joint tenancies in the face of mounting criticism has also been explained in terms of the general practitioner's failure to understand the drawbacks of joint ownership and to offer "equally attractive but more economical alternatives." Riecker, Joint Tenancy: The Estate Lawyer's Continuing Burden, 64 MiCH. L. REv. 801, 802 (1966). In fact, lawyers may have encouraged joint tenancies through benign neglect as a result of congressional response to the increasing popularity of the joint tenancy. Id. at 805-10. Whatever the explanation for this popularity, the common inyths about the advantages of joint ownership need debunking. Id. at 810-16.

34. See Riecker, supra note 33 , at 830 . Congress recognized this preference on the part of taxpayers when it passed a special gift tax provision which excepted real property held by husband and wife as joint tenants with the right of survivorship. See INT. REV. CODE OF 1954, \& 2515. The Treasury Department, in its 1969 proposals for reform of the estate and gift tax provisions, also expressly recognized the prevalence of the "ours" concept and recommended that transfers between husband and wife not be subject to the transfer tax.

The present system of taxing transfers between spouses does not accord with the common understanding of most husbands and wives that the property they 
joint tenancy with right of survivorship, and tenancy by the entirety. ${ }^{35}$ A tenancy in common is a type of a co-ownership of real or personal property in which each of the cotenants has a distinct and separate interest in the property but each tenant is entitled to possession and enjoyment of the entire property subject to the same right in the other cotenants. ${ }^{36}$ More importantly, each tenant in common has the unfettered right to dispose of his interest by will; if he fails to do so, it will pass at his death under the controlling intestate statute. ${ }^{37}$ During his lifetime he may transfer his interest or encumber it without the consent of the other tenant in common. Moreover, any transferee will be admitted to all the rights and privileges enjoyed by the transferring tenant in common. ${ }^{38}$

A joint tenancy with right of survivorship is distinguished froin a tenancy in common essentially only in respect to the survivorship feature. ${ }^{39}$ A cotenant in property held as joint tenants with right of survivorship may alienate or transfer his fractional interest in the jointly held property at any time during his lifetime. ${ }^{40}$ At his death, however, he loses control over the property. The survivorship feature causes the deceased cotenant's fractional interest to expire and the surviving cotenant's interest to expand to include the entire interest in the property. ${ }^{41}$

have accumulated is "ours". TAX REForm Studies AND PRoposals, supra note 12 , at 358 .

35. For a discussion of the characteristics of joint tenancies, tenancies by the entireties and tenancies in common, see $1 \mathrm{~J}$. MERTENS $\S \S 11.03$ \& 11.04; Effland, supra note 3. See also Rich, Joint Ownership of Property and Joint Wills, 15 N.Y.U. INST. OF TAXATION 825 (1957).

36. C. MOYNIHAN 224.

37. See 2 AM. LAW Property $\$ 6.10$, at 46.

38. Id. See also A. CASNER 401.

39. There are some other technical differences, the practical consequences of which vary from state to state. The joint tenancy relationship is described as the fictional unity of persons as co-owners. This unity is usually expressed in terms of unity of interest, unity of title, unity of time, and unity of possession. At common law this concept of unity of persons required co-owners to acquire their interest at the same time and by the same instrument. In some jurisdictions, this remains the rule and a husband, for example, cannot create a joint tenancy with his wife without deeding the property to a strawman and having the straw deed it back to husband and wife as joint tenants with right of survivorship. C. MOYNIHAN 216-23; see 2 AM. LAW PROPERTY $\S 6.2$.

40. The transfer of a fractional interest in property held as joint tenants with right of survivorship converts the joint tenancy into a tenancy in common. If there were originally more than one joint tenant, the remaining original joint tenants continue to hold their interests as joint tenants with right of survivorship but the transferee tenant holds as a tenant in coinmon. "The transfer destroys the unities of title and of time since the transferee acquires his interest by a different title and at a different time ...." c. Moynihan 221.

41. See generally 2 AM. LAw Property § 6.2, at 7-11. 
A tenancy by the entirety (which also has a survivorship feature) is distinguished from a joint tenancy in several respects: (1) it may be created only between husband and wife;2 (2) neither spouse can alienate or transfer his imterest in the subject premises without the consent of the other tenant by the entirety; ${ }^{43}$ (3) not all states recognize tenancy by the entirety; ${ }^{44}$ and (4) of those states recognizing tenancy by the entirety, the majority restrict it to real property. ${ }^{45}$ It is also important to note that in some jurisdictions the husband has full control of the tenancy by the entirety property during the joint lives of himself and his spouse. In those jurisdictions, the husband has the right to all of the income from the entirety property and, in some cases, he can encumber it or subject it to the claims of his creditors. ${ }^{46}$ On the other hand, the majority rule is that each tenant by the entirety has an equal right to the imcoine froin the entirety property and that creditors of one tenant by the entirety may not subject the entirety property to their claims. ${ }^{47}$ In fact, however, even in those jurisdictions in which the husband can subject the entirety property to the claims of his creditors, those claims will be defeated if the other spouse survives. In other words, the survivorship feature is superior to the right of a creditor of one of the tenants to subject the entirety property to his claims. ${ }^{48}$

It must be emphasized that when title is taken by husband and wife as joint tenants or tenants by the entirety, each of them will be deemed to have a vested present (but undivided) fractional interest in the tenancy. This is a state law determination made without regard to the respective contributions of the spouses to the purchase price. ${ }^{40}$ In cases where the contributions of the spouses are not equal, it would seem appropriate to conclude that the spouse contributing the greater amount has inade a gift for state law purposes to the other spouse by

42. See id. $\S 6.6$, at $23-24$.

43. In a few jurisdictions, including New York and New Jersey, it has been held that each tenant by the entirety may dispose of his interest in the tenancy by the entirety without the consent of the other tenant. However, even in those jurisdictions, the conveyance will not defeat the right of survivorship nor the right to possession of the tenant who has not conveyed his imterest. Id. $\$ 6.6$, at 28-29; C. Lowndes \& $\mathbf{R}$. KRAMER $\$ 11.1$, at 230.

44. See 4A R. POWELl \& P. Rohan T 621 , at 684.

45. See 2 AM. LAW Property $\$ 6.6$, at 30; C. MOYNIHAN 230-35.

46. 4A R. POWELL \& P. Rohan T 623, at 696, 703, 705.

47. Id. at 697.

48. See 2 Am. Law Property $\S 6.6$, at 28-29.

49. See C. Moynthan 217, 229. The ownership interests of tenants in coinmon need not necessarily be eqnal although there is a presumption of equality of interest where property is transferred to two or more persons. Id. at 224 n.3. 
the amount by which his contribution exceeds the value of the interest in the tenancy which state law gives him. ${ }^{50}$

There is a glaring exception to these principles when joint bank accounts are involved. In many cases there is often genuine concern -and real litigation-over whether a deceased joint tenant who has contributed to a joint bank account intended his contribution to become the sole property of the surviving joint tenant at the deceased tenant's death. While each tenant is presumed to have an equal undivided fractional interest in the joint bank account, the courts are increasingly willing to take evidence directed toward overcoming this presumption. ${ }^{51}$

Thus, a general rule of state property law is easily stated: Except in the case of bank accounts, title appears determinative of ownership questions without regard to the respective contributions of the coowners. Applying the old bromide that federal taxing statutes follow state property law determinations, ${ }^{52}$ it would seem logical that each coowner would have included in his gross estate for federal death tax purposes the fair market value of the fractional interest state law believes him to have. It would also seem logical to conclude that when title is taken as joint tenants, the federal gift tax would apply to the difference between the fair market value of the interest acquired by a co-owner and his contribution to the purchase price.

Federal tax law, however, does not follow state law in this area. Under federal law, all joimtly held property is mcluded in the estate of the first to die of the joint tenants except to the extent the survivor can prove contribution. ${ }^{53}$ The emphasis is on contribution without

50. See notes 57-63 infra and accompanying text for discussion of federal gift tax consequences.

51. See, e.g., Frey v. Wubbena, 26 I1l. 2d 62, 185 N.E.2d 850 (1962); Annot., 43 A.L.R. 3d 971 (1972); Effland, supra note 3, at 517-21.

52. Commissioner v. Estate of Bosch, 387 U.S. 456 (1967); see C. LOWNDEs \& R. KRAMER $\$ \$ 4.15-.28,52-57$.

53. See INT. Rev. Code of 1954, \& 2040. The term "property held jointly" is defined in Treas. Reg. $\$ 20.2040-1$ (b) (1958). The term includes both real and personal property held in a joint tenancy, a tenancy by the entirety, or a joint bank account payable to the survivor. Id. Property held in a tenancy in common is specifically excluded from jointly held property. Id.

The amount excluded from the estate of the first joint tenant to die is not the amount contributed by the survivor but that portion of the value of the joint property which is proportionate to the survivor's contribution. C. LOWNDES \& R. KRAMER $\S$ 11.2 , at 231. There is considerable litigation with respect to what constitutes the survivor's contribution. See 2 J. MERTENS $\$$ 15.05-.06 (Supp. 1970).

There is an important exception in the statute for jointly held property acquired by gift, devise or bequest. See INT. REv. CODE OF 1954, $\$ 2040$. Where property is thus acquired, the proportionate contributions of the joint teuants are determined by 
regard to state law determinations of the respective ownership interests. 54 More importantly, the statute expressly conteinplates "tracing." Th5 means that the source of the contribution made by the surviving joint tenant is always at issue. If the surviving joint tenant's contribution is made from resources provided to her by the decedent, the value of the jointly held property proportionate to these recources will be included in her gross estate. ${ }^{56}$ It is an efficient inechanical rule that puts the burden of proof on the surviving joint tenant.

It is surprising, then, to note that the federal tax on gifts-lifetime transfers for less than adequate and full consideration im money or moneys worth in other than a business context ${ }^{57}$-follows state law determinations with one notable exception. The importance of the exception is such that it is frequently stated first. When husband and wife take title to real property as joimt tenants with right of survivorship (or as tenants by the entirety) ${ }^{58}$ they have the option of reporting

the interests which the tenants take under local law. Treas. Reg. $\S 20.2040-1(c)$ (1954).

54. More important, perhaps, is the fact that payment of federal gift tax by the spouse who made the larger contribution at the time property becomes jointly held does not avoid application of the federal estate tax to such jointly held property at the death of the first joint tenant to die. There is, of course, a credit against the decedent's federal estate tax liability for federal gift taxes paid on property included in the dcccdent's gross estate. See INT. REv. CODE OF 1954, § 2012.

55. INT. REv. CODE OF 1954, $\$ 2040$. The difficulty of tracing the survivor's contributions is well illustrated by Estate of Mead v. Commissioncr, 11 P-H Tax Ct. Mem. If 42,236 (1942).

56. See Treas. Reg. $\S 20.2040 .1$ (c)(4) (1954). Thus, the survivor cannot claim as her contribution a gift she received from the decedent. $C f$. Estate of Edward $T$. Kelley, 22 B.T.A. 421 (1931).

The tracing principle represents a reasonable attempt to emphasize substance over form. A taxpayer should not be able to defeat the death tax on jointly held property by funneling a portion of the consideration for such property through the other joint tenant. There is, however, a surprising limitation to this doctrine where income producing property is involved.

If the decedent, before the acquisition of the property by himself and the other joint tenant, transferred to the latter for less than an adequate and full consideration in money or money's worth other income-producing property, the income from which belonged to and became the other joint owner's entire contribution to the purchase price, then the value of the jointly-held property less that portion attributable to the income which the other joint owner did furnish is included in the decedent's gross estate. Treas. Reg. \& 20.2040-1(c) (5) (1954).

57. See INT. Rev. Code of 1954, $\S \S 2501,2511,2512$; Treas. Reg. $\$ 25.2512$ 8 (1958). See generally 5 J. MERTENS $\$ \$ 36.06-36.07$ (Supp. 1971).

58. The Service construes the meaning of real property narrowly. "In providing in section 2515(a) of the Code an exception from gift tax provisions of the creation of tenancies by the entirety in 'real property,' Congress indicated in no way a modification of the concept as used at common law." Rev. Rul. 66-40, 1966-1 CuM. Bull. 227, 
or not reporting the transaction for federal gift tax purposes. ${ }^{59}$ With respect to all other property, federal law defers to state law. If state law declares that a co-owner took a greater interest in property than his contribution would entitle him to, the other co-owner is deemed to have inade a taxable gift to the extent the fair inarket value of the interest taken by the other co-owner exceeds his contribution. ${ }^{60}$ In the case of joint bank accounts, federal law also follows state law. Since under state law, the interest of each co-owner in a joint bank account is limited, practically speaking, ${ }^{61}$ so too, under federal law, no gift is made until a co-owner withdraws an amount in excess of her contribution to the account. ${ }^{62}$

229 (for example, a taxpayer's interest in a cooperative apartment does not qualify as real property for purposes of section 2515 (a)).

59. See INT. REv. CODE of 1954, § 2515. See notes 92-101 infra and accompanying text.

60. See Treas. Reg. $\$ 25.2511-1(\mathrm{~h})(5)$ (1954). See notes $92-99$ infra and accompanying text.

The Treasury Regulations are silent with respect to the gift tax consequences of creating tenancies in common, but it seems clear that a taxable gift will occur where the fractional interests received by the tenants in common are disproportionate to their contributions to the purchase price of the property. C. LOWNDES \& R. KRAMER $\$ 30.2$, at 657 .

It would be unusual to find that the joint owners had considered the gift tax implications of taking title as joint tenants. Rarely is a gift tax return filed in these cases. Of course, in many cases, the $\$ 3,000$ per donee per annum exclusion and the $\$ 30,000$ exemption provided by sections $2503(\mathrm{~b})$ and 2521, INT. Rev. CODE OF 1954, respectively, frequently eliminate any tax liability. In those cases where the annual gifts exceed $\$ 3,000$, lowever, gift tax returns must be filed even if no tax is due because of the exemption. More often than not, it is difficult at estate planning time to determine if gift tax returns should liave been filed for gifts made in prior years. In most cases, the client has no records from which to reconstruct these transactions, and, for that reason, the tendency seems to be to shy away from filing delinquent returns. Unfortunately, the statute of limitations will not begin to run on these transactions until a return is filed. See id. $\$ 6501(c)(3)$. A delinquency penalty of $25 \%$ of the tax, id. $\$ 6651$, and a negligence penalty of $5 \%$, id. $\$ 6653(\mathrm{a})$, may be due. See Ellen W.S. Jolnston, 27 CCH Tax Ct. Mem. 1401 (1968) (Dec. 29,233 (M)) (gift tax penalties assessed in 1966 on a 1945 gift resulting from the creation of tenancy by the entirety).

61. See text accoinpanying note 51 supra.

62. See Treas. Reg. 25.2511-1(h)(4) (1958) which provides:

If $\mathrm{A}$ creates a joint bank account for himself and $\mathrm{B}$ (or a similar type of ownership by which A can regain the entire fund without B's consent), there is a gift to $B$ when $B$ draws upon the account for lis own benefit, to the extent of the amount drawn without any obligation to account for a part of the proceeds to A. Similarly, if A purchases a United States savings bond, registered as payable to "A or B," there is a gift to B when B surrenders the bond for casli without any obligation to account for a part of the proceeds to A. Id.

Lowndes and Kramer speculate about the situation where under local law the donor-spouse does not have the right to regain the entire fund:

Presumably, if under some peculiar doctrine of the local law, or some contractual arrangement, when a person deposited money in a joint bank account this 
In the case of tenancy by the entirety property, the value of the gift is calculated differently to reflect the fact that neither tenant can sever the tenancy without the consent of the other tenant. This restraint on alienation places a premium on survivorship probabilities. The spouse with the greater life expectancy clearly has a more valuable interest in the property. The Internal Revenue Service provides tables and factors which take into account the actuarial probability that one tenant will survive the other. ${ }^{63}$

\section{Termination of Joint Tenancy During Life}

\section{A. Objective: Estate Equalization}

It is fairly clear that federal estate tax considerations make it highly desirable for a husband and wife to have equal estates, and that accordingly, it is often desirable to accomphish such equalization through lifetime property transfers between the spouses. This can be illustrated by a simple example. Assume $H$ and $W$ are husband and

created a joint tenancy with respect to the money so that the depositor lost title to half of the money at the time the deposit was made, and he could not withdraw half of the account so that the transfer of that half was complete and irrevocable, this would be a gift of half of the account to the other depositor at the time the deposit was made. C. Lowndes \& R. KrAMER $\S$ 30.10 , at 666-67.

The Service has ruled that where a United States savings bond is acquired by one person from his separate property and is payable either to him or another person, there is not a completed gift unless (1) the noncontributing co-owner cashes the bond or (2) the bond is reissued in the name of the noncontributing co-owner alone. Rev. Rul. 55278, 1955-1 CuM. BuLl. 471, 472; see C. LOWNDES \& R. KRAMER $\$ 30.10$, at 667 .

The courts at first did not follow this ruling. In Silverman v. McGinnes, 259 F.2d 731 (3d Cir. 1958), the Third Circuit held that a completed inter vivos gift of savings bonds had been made where the contributing co-owner had delivered the bonds into the possession of the noncontributing co-owner with the intention of making a gift. The bonds had not been cashed by the noncontributing co-owner nor had they been reissued in his name alone. However, im United States v. Chandler, 410 U.S. 257 (1973) (per curiam), the Supreme Court held that even though the decedent had made a valid gift of savings bonds under state law, the bonds were includible in his estate under section 2040 because the federal regulations require that the bonds be reissued in order to change ownership. See also Estate of Curry v. United States, 409 F.2d 671 (6tl Cir. 1969); Mae Elliott, 57 T.C. 152 (1972) (upholding the Service's position).

See generally Rev. Rul. 68-269, 1968-1 CuM. BuLL. 399 (Situations 2-5, 7-gift tax payable on savings bonds in various factual situations).

Joint brokerage accounts where the contributing co-owner could withdraw all of the funds are also treated like joint bank accounts. See Rev. Rul. 69-148, 1969-1 CUM. BULL. 226.

63. IRS Publication 723A, Supplement 1 (4-71), Actuarual Values II: Factors at 6 Percent Involving ONe and Two Lives, in 2 CCH Fed. Est. \& Gift Tax REP. T 8033 (1971).

There has been some question whether the creation of a tenancy by the entirety could constitute a gift, but that has been clearly settled in favor of gift treatment. See 5 J. MERTENS $\$ 36.09$. 
wife and that $\mathrm{H}$ has a $\$ 200,000$ adjusted gross estate and that $\mathrm{W}$ has no property of her own. If $\mathrm{H}$ predeceases $\mathrm{W}$ and devises all of his property to her, his federal estate tax hability will be $\$ 4,800$, but at W's death, her federal estate tax liability will be $\$ 32,700$ unless she consumes some of H's property after his death or otherwise disposes of it. Of course, if $\mathrm{W}$ predeceases $\mathrm{H}$, there would be no federal estate tax liability at W's deatl. In sucl cases, however, the federal estate tax liability at H's subsequent death would be $\$ 32,700$.

On the other hand if $\mathrm{H}$ were to be taxed on only $\$ 100,000$ of the $\$ 200,000$ and $W$ on the other $\$ 100,000$, their respective federal estate tax bills would each be $\$ 4,800$. To accomplish this objective it is important that none of the property included in the estate of the first spouse to die be included in the estate of the survivor at her subsequent death. ${ }^{64}$

Thus, it is imperative that all joint tenancies with right of survivorship and tenancies by the entirety be terminated. To allow sucli arrangements to continue would mean that all jointly held property will be included in the estates of both spouses ${ }^{65}$ (unless they die simultaneously ${ }^{66}$ ), thereby making equalization impossible. ${ }^{67}$

64. This is necessary to avoid taxing the same property in both estates. The importance of this principle was discussed earlier. See text accompanying note 24 supra.

65. Inclusion of the same property in the estate of the second spouse to die would not have any effect on the federal tax liability of the estate of the first spouse to die because of the availability of the inarital deduction in the estate of the first spouse to die as to that property passing to the surviving spouse. See INT. REv. CODE OF 1954, § 2056. It would, however, increase the total transfer tax to be borne by the estates of both spouses. The inclusion of the same property in both estates would inflate the survivor's estate and thereby substantially increase her federal estate tax liability largely because of the progressive rate structure of the federal estate tax. See id. $\$ 2001$. For example, assume each spouse dies with a $\$ 100,000$ adjusted gross estate and makes no gifts to charity and no part of either estate qualified for the marital deduction. After taking the $\$ 60,000$ estate tax exemption, see $i d$. $\$ 2052$, each taxable estate will be $\$ 40,000$ and thus taxed as an $18 \%$ bracket estate. Id. The tax will be $\$ 4,800$ on each estate. On the other hand, if the respective estates were combined and all included in the estate of the first spouse to die, his adjusted gross estate would be $\$ 200,000$, and, after allowing for the inarital deduction as to that property passing to the surviving spouse, his estate would also be taxed as an $18 \%$ bracket estate. Id. The tax on his estate would again be $\$ 4,800$. However, at the death of the survivor, the full $\$ 200,000$ will be included in her estate (unless she consumes it or disposes of it during lifetime). The survivor's $\$ 200,000$ adjusted gross estate (assuming no gifts to charity aud no marital deduction) will be treated as a $28 \%$ bracket estate. Id. The tax at her death will be $\$ 32,700$.

66. See Uniform Simultaneous Death ACt $\$ 3$. In those cases where there is no sufficient evidence of the order of deaths, jointly held property will be distributed "one-half as if one (jomt tenant) had survived and one-half as if the other had survived." Id. All jurisdictions except Ohio have adopted the Uniforin Act. For local variations, see 8 UNIFORM LAWS ANNOTATED 617-18 (Master ed. 1972).

Rev. Rul. 66-60, 1966-1 Cum. Bull. 221, provides that 
Estate equalization may be less than appealing to many taxpayers if they are told that at the death of the first spouse to die, the survivor can have no further interest in the decedent's property. For that reason, it is imperative that any suggestion of estate equalization be accompanied by a recommendation that the property belonging to the first spouse to die will be placed in a trust for the surviving spouse. If the trust is properly drafted, the survivor will have the enjoyment of the property included in the estate of the first spouse to die without the burden of having it included in her gross estate for federal estate tax purposes. This can be accomplished by virtue of a carefully drafted trust agreement included in the will of the first spouse to die. ${ }^{18}$ The trust should provide that the surviving spouse shall enjoy all of the income from the trust property for life. The draftsman can go even further and give the survivor a power to appoint the remaimder interest among a limited class of persons (excludimg herself, her estate, her creditors, or the creditors of her estate) without adverse death tax consequences. ${ }^{69}$ With even more careful craftmanship, the survivor could be made trustee of her deceased spouse's property and the property would still not be included in her gross estate. ${ }^{70}$

under section 3 of the Uniform Simultaneous Death Act, a presumption of survivorship in the wife is created with respect to half of the property held by the entirety. With respect to this property she has survived and the property passes to and is includible in her estate. Therefore, the husband's estate is entitled to a marital deduction to the extent of the one-half interest passing to the wife. Id.

Thus, in such cases, one-half of the jointly held property will be included in the cstate of each decedent. See INT. REv. CoDE OF 1954, \$ 2033.

67. Jointly held property would be included in the estate of the first spouse to die except to the extent the survivor could prove contribution. INT. Rev. CoDE of 1954, $\$ 2040$. It would subsequently be in the estate of the survivor at her subsequent death unless she consumed it or disposed of it during her lifetime. See text accompanying notes 24-25 supra.

Even if contribution to the jointly held property can clearly be established when the first spouse dies, it would not be appropriate to continue to hold property as joint tenants with right of survivorship or as tenants by the entirety. To do so, would, of course, mean that the portion taxed in the estate of the first spouse to die would again be included in the estate of the survivor at his subsequent death unless the jointly held property was consumed or disposed of by the survivor. However, in fairness, it must be said that if contribution to the jointly held property can be established, estate equalization wonld be possible without terminating the joint tenancy arrangements if only there were some way to predict which spouse will die first. If their order of deaths cannot be determined, all attempts at equalization will be frustrated so long as the spouses have jointly held property since there is no way to prevent all of the jointly held property from vesting in the surviving spouse at the death of the first to die.

68. In those jurisdictions where testamentary trusts are subject to continuing court supervision, an alternative would be to pour-over the decedent's probate property to an existing revocable trust. See note 20 supra.

69. See INT. REv. CODE OF 1954, \& 2041. See note 23 supra.

70. In order for the federal estate tax to be applied to property interests passing 
There are two possible disadvantages of this scheme. The first is that the trust device denies the survivor the unfettered dominion and control over the deceased spouse's property which she would have if she took this property outright. This, however, is a modest restriction on the enjoyment of the property and one that the taxpayer must be prepared to accept. All tax planning is a process of compromising objectives. If a taxpayer wants to enjoy tax savings, he must give up some control over his property. If control is a premium item, the taxpayer must be prepared to pay a full share of taxes. He cannot have it both ways.

The second reason which may be advanced as a disadvantage of this scheme has to do with the suggestion that all joint tenancies and tenancies by the entirety should be terminated. In many cases one of the spouses has made all of the contributions necessary to acquire the jointly held property. In that case, if the noncontributing spouse is the first to die and the surviving spouse can prove the extent of his contribution to the jointly held property, the deceased spouse's estate may be reduced to the point that all of her estate will pass tax free to the survivor. ${ }^{71}$ But whether there is any ultimate transfer tax savings in such a case will, of course, depend upon the survivor with the larger estate undertaking an aggressive gift program to reduce the size of his gross estate. Otherwise the federal estate tax liability at his death will greatly exceed the total federal estate tax liability which would have been incurred had the property been split between the spouses while they were both living. ${ }^{72}$ But even an aggressive gift program after the death of the spouse with the smaller estate has serious disadvantages. It means the surviving spouse cannot retam a life

from the still to the quick, two conditions must be satisfied. First there must be a transfer at some time-either during lifetime or at deathtime-from this decedent. Second, there must be a shifting of economic benefit-direct or indirect-from this decedent at his death. In the case where the surviving spouse has a life estate in the deceased spouse's property, a power to appoint among a limited class of persons, and is also the trustee of that property, nothing will be included in her estate because she has never made a transfer of this property even though the economic benefit of the property shifts from her at her death. In other words, she has not satisfied both of the conditions for the application of the federal estate tax. See INT. REv. CoDE OF 1954, §§ 2033-42.

Perhaps it is appropriate to note that in cases where the surviving spouse is trustee, she can be given discretion to distribute principal to herself provided her discretion is limited by an ascertainable standard such as "maintenance, care and support." See id. $\S 2041$ (b)(1)(A).

71. Combining the marital deduction (INT. Rev. CODE OF 1954, § 2056) and the federal estate tax exemption (Id. $\$ 2052$ ) will allow $\$ 120,000$ to pass from a decedent to his surviving spouse free of any tax.

72. See notes 64-67 supra and accompanying text. 
estate in any of the property he transfers if he wants to keep that property out of his gross estate. ${ }^{73}$ On the other hand, if the respective estates are equalized while both spouses are living, the survivor can enjoy a life estate in the deceased spouse's property without adverse tax consequences. ${ }^{74}$ The only real advantage, then, of not equalizing the estates is the possibility that there will be a tax deferral if the spouse with the sinaller estate dies first. Thus, when the estates are equalized some tax will be paid at each spouse's death. In the case where they are not so equalized and the spouse with the smaller estate dies first, in many cases no tax will be immediately due and payable and the tax dollars saved will be available to the survivor.

This can be illustrated by reference again to the case of a taxpayer with a $\$ 200,000$ gross estate, $\$ 150,000$ of which consists of jointly leeld property for which he provided all the consideration. This taxpayer and his spouse should make a lifetime split of their jointly held property so as to give eacli spouse a $\$ 100,000$ gross estate. Each spouse should then execute a will providing the survivor of them a life estate plus a limited power of appointment over the property included in the estate of the first spouse to die. ${ }^{75}$ Assuming no increase in the value of the survivor's estate, the death tax bill at the death of each spouse will be $\$ 4,800$ or a total transfer cost of $\$ 9,600$. Had the property remained in joint tenancy and the surviving spouse received the entire estate of the first to die, the death tax bill would be $\$ 4,800$ upon the death of the first to die, and $\$ 32,700$ upon the death of the second to die, for a total transfer cost of $\$ 37,500 . .^{70}$ Or if the taxpayer had employed the traditional $A$ and $B$ trust arrangement for the property, the death tax bill at his death would again be $\$ 4,800$ and at his spouse's subsequent death, $\$ 17,900$, for a total transfer tax cost of $\$ 22,700 .^{77}$

73. See note 19 supra and accompanying text. Of course the donor could make a lifetime transfer of property in trust aud give the trustee absolute discretion over whether to make any distributions of principal or income for his benefit. See note 274 infra and accompanying text.

74. See text accompanying notes 64-70 supra.

75. See text accompanying note 70 supra.

76. The tax consequences would be approximately the same even in cases where the first spouse to die provided none of the consideration for the jointly held property and had no other property. For example, all the jointly held property would initially be included in her gross estate under a rebuttable presumption. INT. REv. CODE of 1954, § 2040. If the presumption was not overcome, the tax bill at the death of the first to die would be $\$ 1,050$. When coupled with the tax bill of $\$ 32,700$ at the death of the survivor (assuming be neither disposed of nor consumed any of the $\$ 200,000$ ) it would mean a total transfer tax of $\$ 33,750$.

77. See note 27 supra and accompanying text. The tax consequences which result 
This comparison can be illustrated by the following table. Line one shows the total estate tax liability of both spouses if their total estate is valued at $\$ 200,000$ and includes $\$ 150,000$ of jointly held property purchased by the husband. The second line indicates the total estate tax liability if an A and B trust arrangement is established by the husband for the same $\$ 200,000$ estate. Finally, the estate tax results of applying the estate equalization device to the $\$ 200,000$ estate are shown in line three. In all three cases, the first column represents the total cost of transferring the property to the next generation in those cases where the husband dies first; the second column shows the results if the wife dies first.

\section{Sum of Federal Estate Taxes Paid by the Spouses}
1. Jointly held property
2. A and B Trust
$\$ 37,500$
$\$ 33,750^{78}$
$\$ 22,700$
$\$ 33,750^{79}$
3. Estate Equalization
$\$ 9,600$
$\$ 9,600$

Husband Dies First

Wife Dies First

The table nakes clear the potentially disastrous estate tax consequences when spouses hold their property jointly. In sum, from an estate tax minimization standpoint, holding property jointly should be strongly discouraged.

\section{B. Obstacle: Federal Gift Tax Considerations}

The tax planning advantages that can be obtained by equalizing the respective estates of husband and wife are complicated when jointly held property is present because of the federal gift tax consequences which frequently result from the termination of such ownership arrangements as the spouses bring about equalization. ${ }^{80}$ These conse-

if the $A$ and $B$ trust arrangement were used and the wife died first would be $\$ 1,050$ at her death and $\$ 32,700$ at his death. The reasons are the same as those given in note 76 supra. Since the taxpayer husband is the survivor, the A and B trust arrangement with its marital deduction feature (INT. REV. CODE OF 1954, \& 2056) will not be operative.

78. It is assumed that all the jointly held property was included in the wife's estate when she died first. See note 76 supra.

79. See note 77 supra. Had the estates not included any jointly held property, then the total federal estate tax when the husband dies first would be $\$ 9,600$, and when the wife dies first, $\$ 32,700$. See note 81 infra.

80. See Worthy, supra note 1 at 620-26. See generally 5 J. MERTENS $\S$ 36.11-18 (Supp. 1971). Perhaps special attention should be called to the fact that equalization can mean that the jointly held property is converted to tenancy in common ownership. The spouses need not have equal interests as tenants in common but their interests as tenants in common will be a factor in determining gift tax consequences upon termination of the joint tenancy arrangement. The discussion in text which follows will illustrate these points. However, in cases where the spouses seek to equalize their estates and contemplate using a trust to hold the property of the first spouse to die, it is ques- 
quences are rarely foreseen by the client and often overlooked by the attorney. Perhaps this is understandable in light of the complexities inherent in making such gift tax determinations. This complexity results from two factors: (1) tax consequences which result from terminating joint tenancies depend upon the kind of property in which the joimt tenancy existed; and (2) in determining gift tax consequences federal law attempts to follow state property law determinations (with some notable exceptions). ${ }^{81}$

tionable whether holding property as tenants in common is advisable. That form of ownership would mean that at the death of one spouse, the trustee of his trust would succeed him as partial owner of the tenancy in common property. That split of ownership could create administrative difficulties. Perhaps a better solution would be to equalize estates by dollar values of entire properties between the spouses rather than fractional interests.

Fortunately, mcome tax considerations affecting lifetime splits of jointly held property are limited to concerns about basis for purposes of determining gain upon ultimate sale of the property. It is well settled, for example, that a division of jointly held property between co-owners or modification of the form of ownership does not constitute a sale or exchange within the contemplation of section 1002 Internal Revenue Code of 1954. See Rev. Rul. 56-437, 1956-2 Cum. Bull. 507; A. CASNER 417 n. 58. But see note 261 infra. For a detailed examination of the income tax consequences which result from property divisions, see Dickinson, Federal Income Tax Treatment of Divisions of Property: Marital Property Settlements, Estate and Trust Distributions, and Other Transactions, 18 KAN. L. REv. 193 (1970).

The federal income tax cannot be ignored, however, in planning lifetime splits of jointly held property. Property included in a decedent's gross estate for federal estate tax purposes will have as its basis for federal income tax purposes the value at which it was reported for federal estate tax purposes. See INT. REv. CODE OF 1954, \& 1014. On the other hand property transferred during lifetime will have as its basis in the hands of the transferee the transferor's basis plus any gift tax paid at the time of the transfer. See INT. Rev. Code of 1954, \& 1015. Thus, lifetime splits of jointly held property can have income tax consequences in the sense that appreciated property will continue to have a low basis for income tax purposes in the hands of the transferee whereas that same property would have a stepped-up basis if it were included in the transferor's gross estate for federal estate tax purposes. Whether this consequence is sufficient to warrant keeping property in joint tenancy form can only be determined by a comparison of the estate tax savings possible if the jointly held property was split with the anticipated incoine tax liability when the property is sold.

81. See text accompanying notes 57-63 supra. A brief overview of gift tax considerations in terminating joint tenancies has appeared in the context of Michigan law. See Kahn, Joint Tenancies to Tenancies by the Entirety in Michigan-Federal Gift Tax Considerations, 66 MrCH. L. REv. 431 (1968).

Perhaps it is also appropriate to comment that because of gift tax considerations, the spouses' respective estates may be more easily equalized where they have jointly held property. For example, assume $H$ has $\$ 200,000$ of separate property and $W$ has none. While $\mathrm{H}$ would probably be inclined to use an A and B Trust for tax purposes, see text accompanying notes 20-24 supra, it would have the tax savings effect of equalizing the spouses' respective estates only if $\mathrm{H}$ died first. On the other hand, if $\mathrm{H}$ 's and W's respective estates were equalized, the order of the spouses' deaths would be irrelevant provided the first to die made certain that no part of his property would be included in the survivor's estate. See note 67 supra and accompanying text. But the 


\section{(1) Joint Tenancy with Right of Survivorship}

There will be no gift tax consequences upon termination ${ }^{82}$ of a joint tenancy arrangement provided each spouse receives property having a value equal to the value of the interest state law gives him or her in the jointly held property. ${ }^{83}$ Valuation of these interests depends upon whether the property is held as joint tenants with right of survivorship or as tenants by the entirety. With respect to property held as joint tenants with right of survivorship, each spouse will be deemed to have acquired an undivided one-half interest in the property when the joint tenancy was created. ${ }^{84}$ The respective contributions of the spouses are irrelevant to this determination. Federal law, in this respect, is merely recognizing the fact that under state law either joimt

gift tax cost of equalizing the estates would mean that equalization was more expensive for tax purposes than would be an A and B trust arrangement, provided, of course, that $H$ died first. If $W$ dies first, equalization would be cheaper.

If $\mathrm{H}$ dies first and the $\mathrm{A}$ and $\mathrm{B}$ trust is nsed, the estate tax at the death of each spouse will be $\$ 4,800$ respectively. There will be no gift tax consequences. On the other hand, if $\mathrm{W}$ dies first, there will be no tax at her death, and at H's death the estate tax will be $\$ 32,700$.

Equalization of $\mathrm{H}$ and W's respective estates will incur a $\$ 952$ gift tax liability provided neither $H$ nor $W$ has exhausted any part of his or her $\$ 30,000$ lifetime exemption. The fact of this gift tax hability will increase the cost of equalization by $\$ 952$ over the $A$ and $B$ trust arrangement in cases where $H$ dies first. Of course, where $W$ dies first, equalization will reduce the total estate tax to $H$ and $W$ to $\$ 9,600$ ( $\$ 4,800$ each) which when added to the $\$ 952$ gift tax liability means a total transfer cost of $\$ 10,552$ versus $\$ 32,700$ without eqnalization.

$\begin{array}{lcc}\text { A and B Trust } & \begin{array}{c}\text { Total tax if } \\ \text { H dies first }\end{array} & \begin{array}{c}\text { Total tax if } \\ \text { E dies first }\end{array} \\ \text { Equalized Estates } & \begin{array}{l}\$ 9,600 \\ \$ 10,552\end{array} & \frac{\$ 32,700}{\$ 10,552}\end{array}$

Of course the gift tax effect will be much greater as the value of H's estate increases.

The advantage of jointly held property in the event of equalization is that there may not be any gift tax consequences because each spouse may be deemed to own (for gift tax purposes) one-half of the jointly held property. See notes 82-101 infra and accompanying text.

82. Termination of a joint tenancy with right of survivorship or a tenancy by the entirety due to the death of one of the tenants is not treated as a termination because any transfer which occurs at that time is testamentary in nature and is subject to the federal estate tax and not the gift tax. See Treas. Reg. $\$ 25.2515-1(b)$ (1954). However, a termination is deemed to have occurred when the tenancy ends in any other way unless the property subject to the tenancy is converted in whole or in part into other real property held under an identical tenancy. See id. $\$ 25.2515-1(d)(2)$. The termination will not change the fact that gift tax may still be owing from the time when the joint tenancy was created. See note 60 supra.

83. C. LOWNDES \& R. KRAMER $\S 30.5$, at 661 . This rule has an exception for real property acquired as joint tenants with right of survivorship or as tenants by the entirety after December 31, 1954 for which no gift tax returns have been filed. See notes 92-101 infra and accompanying text.

84. See Treas. Reg. $\$ 25.2511-1(\mathrm{~h})(5)$ (1954). 
tenant may sever the jomt tenancy and transfer his one-half interest without the consent of the other tenant. ${ }^{85}$ Therefore, if upon termination, each spouse receives one-half of the property, there will be no gift tax consequences. $^{86}$ If either spouse receives more or less, a taxable gift will have been made by the spouse receiving less than one-half.

\section{(2) Tenancy by the Entirety}

Where tenancy by the entirety property is involved, the only difference in treatment has to do with valuation of the spouses' respective interests in the jointly held property. To determine whether a gift is made at the time of acquisition, the value of the spouses' respective interests in the jointly held property is determined by use of actuarial factors which take into consideration the probability of one spouse surviving the other. ${ }^{87}$,The probabilities of survival change as the spouses get older. ${ }^{88}$ Accordingly, at the time of termination, the interests of the respective spouses in the jointly held property must again be determined actuarially. As in the case of joint tenancy with right of survivorship, the tenancy by the entirety property must be divided so as to enable each spouse to receive property having a value equal to the actuarially determined value of his or her interest in the jointly held property at the time of termination. ${ }^{89}$ Otherwise, a taxable gift will be made by the spouse receiving less than the actuarially determined value of his interest.

\section{(3) Joint Bank Accounts}

Where the property being divided is a joint bank account, different rules will be employed. At the time the account was established, the interests of the respective co-owners for federal gift tax purposes were deemed to be proportionate to their contributions. ${ }^{90}$ A gift from one co-owner to the other is recognized only when a co-owner draws from the account an amount in excess of his contribution. ${ }^{91}$ Thus any

85. See id. $\$ 25.2515-2(\mathrm{~b})(1)$. See note 40 supra and accompanying text.

86. See Treas. Reg. $\$ 25.2515-4$ (b) (1954); C. Lowndes \& R. KrameR $\$ 30.3$, at 659 .

87. See Treas. Reg. $\$ 25.2515-2(b)(2)$ (1954).

88. See note 63 supra and accompanying text.

89. See Treas. Reg. $\$ 25.2515-4$ (b) (1954).

90. See note 62 supra.

91. See note 62 supra. There is a taxable gift only if a direct payment of the amount withdrawn would have been a gift. C. LownDES \& R. Kramer $\$ 30.10$, at 666. Thus, where the wife withdraws funds from the joint account to apply against household expenses there would be no gift. Id.; Rudick, Federal Tax Problems Relating to Property Owned in Joint Tenancy and Tenancy by the Entirety, 4 TAx L. REv. 3, 21 (1948). 
division of the joint account other than in proportion to the respective contributions of the co-owners results in the imposition of the federal gift tax on the amount by which each co-owner's distribution exceeds the portion of the account attributable to his contribution.

\section{(4) Section 2515 Property}

Special legislation exists to exempt from gift taxation, at the taxpayer's option, real property acquired after 1954 by husband and wife as joint tenants with right of survivorship or as tenants by the entirety.92 If no gift tax returns have ever been filed to reflect any transactions with respect to the section 2515 property, gift tax consequences, at the time of termination, depend upon whether the spouses receive property having a value equal to the value of their interests in the section 2515 property. $^{93}$ In this case, valuation depends upon contribution. ${ }^{94}$ Each spouse's interest in the section 2515 property is determined by a fraction, the numerator of which consists of his or her contribution to the property; and the denominator of which is total contributions to the property. ${ }^{95}$ So long as each spouse receives upon termination of the jomt tenancy arrangement the value of his or her fractional interest in the section 2515 property, no taxable gifts will have been made. ${ }^{06}$

On the other hand in cases where the spouses elect to report taxable gifts with respect to section 2515 property, gift tax treatment at the subsequent termination of the co-ownership arrangement will be identical to that experienced with other forms of property held as joimt tenants with right of survivorship or as tenants by the entirety. ${ }^{97}$

In summary form, then, the following points must be noted with respect to section 2515 property:

a. Whether the property is held as joint tenants with right of survivorship or as tenants by the entirety is only important as to property acquired prior to 1955 and property acquired subsequent to that time for which federal gift tax returns have been filed. In such cases which imvolve joint tenancy with right of survivorship property, a taxable gift will have been inade if one tenant contributed more than one-half the total

92. INT. Rev. Code of 1954, $\$ 2515$ (a); C. Lowndes \& R. KrAmeR $\S 30.4$, at 659-60.

93. INT. REv. CoDE OF 1954, § 2515(b).

94. See Treas. Reg. \$ 25.2515-1(b) (1954).

95. See id. \$§ 25.2515-3(a), (b).

96. See id. $\$ 25.2515-1$ (b).

97. See id. §§ 25.2515-2(b)(1), (2), (c), (d); C. LoWNDES \& R. KRAMER $§ 30.5$. 
consideration provided for the property. ${ }^{98}$ At termination a taxable gift will have been made if one tenant receives less than one-half the total property. ${ }^{99}$ Thus, in the case where one spouse provided all the consideration and, at the termination of the joint tenancy, took back all the property, he would be deemed to have made a taxable gift to his spouse at the time of acquisition and she would have been deemed to have made a taxable gift to him at termination. These tax liabilities cannot be offset against each other.

The only difference in treatment where tenancy by the entirety is involved has to do with the computation of the value of the respective tenant's interest in the entirety property at the time of acquisition and at the time of termination. These are questions of valuation only. ${ }^{100}$

b. Whether the property is held as tenants by the entirety or joint tenants with right of survivorship is completely irrelevant in determining federal gift taxes at termination of the co-ownership arrangement where real property was acquired after 1954 and no gift tax returns were filed to reflect the taxable transfer, if any, which took place at the time. In cases like this, termination of the co-ownership arrangement will have no gift tax consequences unless the property is divided other than according to the spouses' respective contributions. ${ }^{101}$

\section{(5) Illustration: Real or Personal Property Held as Tenants} by the Entirety

Tenancy by the entirety in personal property whenever acquired ${ }^{102}$ (except bank accounts); ${ }^{103}$ tenancy by the entirety in real property acquired prior to $1955 ; ;^{104}$ and tenancy by the entirety in real property acquired after 1954, but reported for gift tax purposes ${ }^{105}$ enjoy the same treatment for federal gift tax purposes. At the time of acquisition, a tenant by the entirety will be deemed to have received a taxable gift from the other tenant to the extent the interest he received in the property exceeds his contribution. The issue here, however,

98. See notes 83 \& 95 supra and accompanying text.

99. See notes $85 \& 95$ supra and accompanying text.

100. See notes 88 \& 95 supra and accompanying text.

101. See Treas. Reg. $\$ 25.2515-1$ (b) (1954).

102. See notes 87-89 supra and accompanying text.

103. See notes 90-91 supra and accompanying text.

104. See notes 87-89 supra and accompanying text.

105. See note 97 supra and accompanying text. 
is to measure the respective interests of the co-owners. Where neither co-owner has a right to sever unilaterally the tenancy and each spouse is entitled to share in the income or other enjoyment of the property, "actuarial factors for the spouses at their respective attained ages at the time the transaction is effected" nust be einployed. ${ }^{108}$ The following example from the Treasury Regulations illustrates the use of actuarial factors: ${ }^{107}$

A husband with his own funds acquires real property valued at $\$ 10,000$ and has it conveyed to himself and his wife as tenants by the entirety. Under the law of the jurisdiction governing the rights of the parties, each spouse is entitled to share in the income from the property but neither spouse acting alone could bring about a severance of his or her interest. The husband elects to treat the transfer as a gift in the year in which effected. At the time of transfer, the ages of the husband and wife are 45 and 40 , respectively, on their birthdays nearest to the date of transfer. The value of the gift to the wife is $\$ 5,708.90$, computed as follows:

Value of property transferred $\$ 10,000.00$

Less $\$ 10,000 \times .42911$ (factor for value of donor's retained rights) $4,291.10$

Value of gift $\$ 5,708.90$

The foregoing example illustrates the computation of federal gift tax consequences at the time property is acquired as tenants by the entirety. In cases where a tenancy by the entirety is to be terminated, the value of the spouses' respective interests in the property will have to be recomputed using actuarial factors for the ages attamed by the spouses at the date of termination. ${ }^{108}$ If the tenancy by the entirety described in the prior example were terminated when the husband is 80 and the wife 75 , the recomputation will look like this:

Value of property transferred $\$ 10,000.00$

Less $\$ 10,000 \times .35795$ (factor for value of husband's interest) $3,579.50$

Value of wife's interest $\$ 6,420.50$

That means upon termination of the tenancy by the entirety, the husband must receive 35.795 percent of the property and the wife must re-

106. See Treas. Reg. $\$ 25.2515-2$ (b) (2) (1954).

107. Id. $\$ 25.2515-2$ (d). The quoted passage reflects the new six percent factors to be used in valuing interests in property transferred after December 31, 1970. Such amendinent was made to the regulation for purposes of including it in this Article but the Treasury has not amended the original published version. It did, however, amend Treas. Reg. $\$ 25.2515-2$ (a) in Treasury Decision 7238, 1973 INT. Rev. Bull. No. 9, at 37 but ignored this section.

108. Treas. Reg. $\$ 25.2514-4$ (b) (1954). 
ceive 64.205 percent. If either spouse receives more or less than the indicated percentages, the spouse receiving less will be deemed to have made a taxable gift to the other spouse of the amount by which the value of the percentage received by the other spouse exceeds the value of her percentage interest in the property. For example, if the property has appreciated to $\$ 100,000$ during the period it was held as tenants by the entirety, the wife must receive $\$ 64,250$ of property to avoid having made a taxable gift to her husband. ${ }^{100}$

\section{(6) Illustration: Real Property Held as Joint Tenants with Right of Survivorship}

The Treasury Regulations are quite detailed, and perhaps attention should be given to several points to illustrate the complexity of the problem. A common transaction is one im which husband and wife acquire residential real property as joint tenants with right of survivorship or as tenants by the entirety. To secure the indebtedness norinally incurred to finance such purchases, it is customary to place a mortgage on the property. Specific timing rules then dictate tax consequences:

a. If the property was acquired prior to 1955 , and the respective interests of the spouses in the property at the time of acquisition were not proportional to their respective contributions to the purchase price, gift tax returns should have been filed to reflect the fact that one spouse made a gift to the other. ${ }^{110}$

109. In cases where the real or personal property is held as joint tenants with right of survivorship, the controlling principle is the state law determination that either tenant has an undivided one-half interest in the property, and either may sever the tenancy by transferring his one-half interest without the consent of the other tenant. See note 85 supra and accompanying text. Thus in the following cases there will be no gift tax consequences at termination of a joint tenancy with right of survivorship provided each tenant receives one-half of the property:

a. Where real property is acquired prior to January 1,1955 ; and

b. Where real property is acquired after December 31, 1954 and gift tax returns were filed at the time of acquisition.

See notes 98-101 supra and accompanying text. Conversion of a joint tenancy into a tenancy in common, for example, would have no gift tax consequences so long as each spouse has a one-half interest in the property as a tenant in common. See note 80 supra.

Howevor, where the real property is acquired after December 31, 1954, and no gift tax returns were filed, the property must be divided according to the contributions each made to the property. See notes 92-101 supra and accompanying text. Whether the property is held as joint tenants with right of survivorship or as tenants by the entirety is irrelevant to this inquiry. Actuarial computations will be similarly irrolevant where tenancy by the entirety property is involvod.

110. See Treas. Reg. $\$ 25.2515-1$ (b) (1954). See notes 82-89, 97 supra and accompanying text. 
b. If the property was acquired subsequent to 1954 , the spouses had the option whether to report any taxable gifts at the time of acquisition. ${ }^{11 x}$

Those rules, however, settle the issue of taxable gifts only with respect to the initial transaction. For example, if one spouse goes on to make all the mortgage payments, he will be deemed to have made a gift to the other spouse each time he discharges her portion of the mortgage obligation. ${ }^{112}$ Nonetheless, when this reduction of imdebtedness is accomplished after 1954, the donor spouse has the option of reporting or ignoring these gifts for federal gift tax purposes. ${ }^{113}$

a. If he chooses to ignore these gifts, when the tenancy is subsequently terminated, the value of the property (or the proceeds, if sold) must be prorated according to the total contributions made prior to 1955 and the total contributions made after $1954 .^{114}$ The property allocated to the post-1954 contributions must be distributed to the donor spouse to avoid gift taxes. ${ }^{115}$ The property allocated to the pre-1955 contributions must be allocated between the spouses according to the interest each had in the property under state law. ${ }^{116}$

b. If the gifts of the mortgage payments are reported for gift tax purposes as made, gift tax consequences upon termination will depend upon whether the property is held as joint tenants with right of survivorship or as tenants by the entirety. If held as joint tenants with riglt of survivorship the jointly held property must be equally divided between the spouses at termination. ${ }^{117}$ If held as tenants by the entirety, on the other hand, the division must be according to the interests of the respective spouses but these interests are determined by actuarial factors. ${ }^{\mathbf{1 1 8}}$

111. INT. Rev. CODE OF $1954, \S 2515$.

112. See Treas. Reg. $\$ 25.2515-3$ (b) (1954). It is assumed that both spouses are jointly liable on the mortgage.

113. See note 59 supra and accompanying text.

114. See Treas. Reg. $\$ 25.2515-4$ (c) (1954). Unless the husband was planning to retitle the property as his separate property, he was probably unwise not to elect to report this as a gift since the annual gift to his wife was only one-half of the $\$ 2,000$ mortgage payment, or $\$ 1,000$-well below the annual exclusion of $\$ 3,000$. Because all of the consideration was paid by the husband, the decision about filing a gift tax return would have no inpact on the husband's or wife's estate tax liability.

115. See note 101 supra and accompanying text.

116. See notes $49-50$ supra and accompanying text.

117. See notes 98-99 supra and accompanying text.

118. The value of the gift can only be determined after determining actuarially the value of each tenant's interest in the property at the time of each mortgage payment. 
These principles can be easily illustrated. Assume that certain property was acquired on December 31, 1954 by husband and wife as joint tenants with right of survivorship for $\$ 40,000$, consisting of cash in the amount of $\$ 10,000$ and a 15 year non-interest bearing inortgage for the balance. The mortgage loan called for annual payments of $\$ 2,000$ until the debt was discharged. The husband provided the $\$ 10,000$ down payment from his separate property and made all the Inortgage payments until it was discharged in 1969. No gift tax returns have ever been filed to reflect any of these transactions. In 1973 the spouses decided to split the property between themselves as tenants in common. To avoid gift tax, the property must be split according to their proportional interests in the property determimed by reference to their respective contributions. Thus, the fair market value of the property inust be prorated between the pre-1955 contribution of $\$ 10,000$ and the post-1954 contribution of $\$ 30,000$. Gift tax returns should lave been filed at the time the property was acquired to reflect the fact that the husband then made a gift of $\$ 5,000$ to his wife. The gift consisted of the value of the undivided one-half interest in the property taken by the wife at the time the property was acquired. (This event was taxable because the wife had not made an equal contribution to the purchase price.) The portion of the property allocated upon termination to the pre- 1955 contribution should be equally divided between the spouses; the portion of the property allocated to the post-1954 contributions should be allocated to the husband. Thus, the wife should be given one-eighth $(\$ 5,000 / \$ 40,000)$ interest as a tenant in comunon and the husband should be given a seven-eighths $(\$ 35,000-\$ 40,000)$ interest as a tenant in common if gift tax liability at the time of the termination of the joint tenancy is to be avoided. ${ }^{119}$

The rules with respect to determining the contributions made by joint owners become even more complex when the property has appreciated or depreciated between contribution dates. The regulations require this appreciation or depreciation to be treated "as though it were additional consideration furnished by the person who furnished the prior consideration." ${ }^{120}$ In the previous example, the husband had inade all the mortgage payments from his separate property. Assume now that the wife made an addition to the property on December

But cf. Treas. Reg. § 25.2515-1(c)(2), Example (3) (1954). (Accumulated appreciation ignored because the appreciation is so gradual and the contributions so numerous.)

119. See Treas. Reg. \& 25.2515-3(b) (1954).

120. $l d . \$ 25.2515-1(\mathrm{c})(2)$. 
31,1959 , by an expenditure of $\$ 12,000$ from her separate propenty. In this case, not only would there be a proration according to the pre1955 contributions, but there would also have to be a proration as of the time the wife made the addition if the fair market value of the property at that time could have been determined. ${ }^{121}$ The total contribution is now $\$ 52,000$ ( $\$ 40,000$ purchase price $+\$ 12,000$ addition), $\$ 10,000$ of which was made prior to 1955 . As a result, on contribution principles the wife has at least a one-eighth interest in the property. ${ }^{122}$ What additional imterest does she have? If the fair market value of the property was $\$ 70,000$ in December 1959 when the addition was made, it means the property had appreciated $\$ 30,000$ since its acquisition in 1954. That appreciation constitutes an additional contribution by each spouse in proportion to their respective total contributions as of the date of the addition. However, for the purposes of allocating appreciation between husband and wife in this exainple, the wife will be treated as having made no contribution to the acquisition of the property prior to her expenditure of $\$ 12,000$ for the addition. ${ }^{123}$ Thus, all of the appreciation between contribution dates will be allocated to the husband. His total contributions at the time of the addition, then, are $\$ 45,000$ ( $\$ 15,000$ allocated contribution $+\$ 30,000$ allocated appreciation) and her total contributions are $\$ 5,000$ (representing her allocated appreciation). In 1973 when the jointly held property is split between the spouses, he is deemed to have made a contribution of $\$ 65,000(\$ 45,000+\$ 20,000$ of additional mortgage payments). She is deeined to have made a contribution of $\$ 17,000(\$ 5,000+\$ 12,000$ addition in 1959). If the husband receives less than a seventy-nine percent $[\$ 65,000 \div(\$ 65,000$ $+\$ 17,000)]$ interest in the property, he is deemed to have made a taxable gift to his wife. ${ }^{124}$ The following schedule summarizes these coinputations:

121. Id.

122. See text accompanying note 119 supra.

123. Thus, even though the down payment was made prior to 1955 and therefore constituted a gift of one-half to the contributor's spouse at that time, this gift is apparently not treated as a contribution by the wife for the purposes of allocating appreciation. See Treas. Reg. $\$ 25.2515-1$ (c) (2), Example (1) (1954):

In $1940, \mathrm{H}$ purchased real property for $\$ 15,000$ which he caused to be transferred to himself and $W$ (his wife) as tenants by the entirety. In 1956 when the fair market value of the property was $\$ 30,000$, W made $\$ 5,000$ improvements to the property. In 1957 the property was sold for $\$ 35,000$. The general appreciation of $\$ 15,000$ which occurred between the date of purchase and the date of W's improvements to the property constitutes an additional contribution by $\mathrm{H}$, having the same characteristics as his original contribution of $\$ 15,000$.

124. See Treas. Reg. $\$ 25.2515-1$ (c) (2) (1954). 


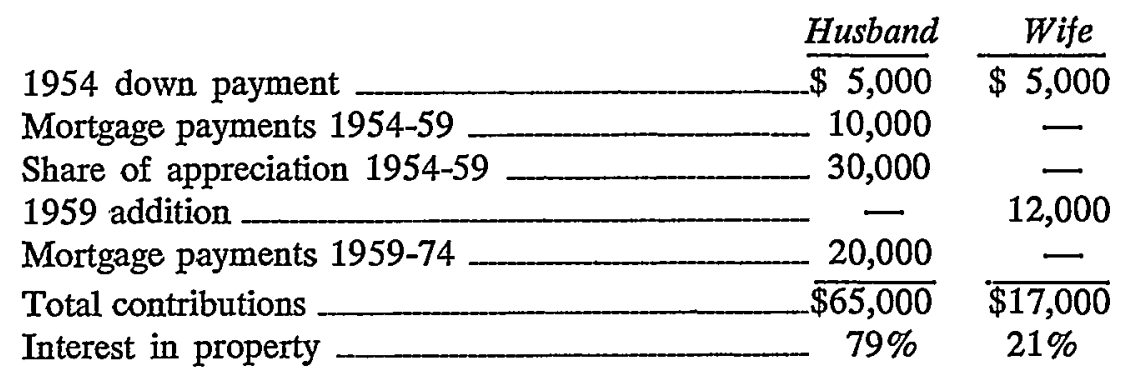

\section{(7) Summary}

Notwithstanding these rather complex and sometimes onerous federal gift tax computations, lifetime sphts of jointly held property remain an attractive alternative. The federal gift tax rates are seventyfive percent of the federal estate tax rates, ${ }^{125}$ and the taxpayer can take advantage of the gift tax marital deduction for gifts to his spouse, ${ }^{120}$ the $\$ 30,000$ exemption, ${ }^{127}$ and the $\$ 3,000$ per donee per annum exclusion. ${ }^{128}$ If neither spouse has made any taxable gifts in prior years, the availability of the exemption, the exclusion, and the inarital deduction will allow one spouse to make $\$ 66,000$ of tax free gifts to the other spouse in the first year of gift giving. In later years the continued availability of the $\$ 3,000$ per donee per annum exclusion and the marital deduction will allow $\$ 6,000$ of tax free gifts from one spouse to the other. In light of these biberal gift tax provisions, the careful planner will frequently be able to accomplish a split of jointly held property free of all gift tax liability. In some cases it may be necessary to accomphish the split over a period of years to avoid all gift tax, but even in cases when it is deemed expedient to bring about an immediate split, the gift tax rates are lardly confiscatory, beginning, as they do, at $2^{1 / 1}$ percent of the first $\$ 5,000$ of taxable gifts. ${ }^{120}$

\section{Non-Tax Considerations}

One of the most significant problems encountered in planning a lifetime termination of jointly held property is the taxpayer's inability to supply records reflecting the respective contributions of the coowners to the jointly held property. Admittedly, determmation of respective contributions is only important for gift tax purposes in the

125. Compare INT. Rev. CoDe of 1954, § 2001 with INT. Rev. Code of 1954, \& 2502(a).

126. See INT. REv. CODE OF 1954, \$2523.

127. Id. \& 2521.

128. Id. $\S 2503(\mathrm{~b})$.

129. Id. \& 2502(a). 
case of joint bank accounts and post-1954 transactions in real property where the co-owners ignored the transaction for gift tax purposes. ${ }^{130}$ But, as a practical matter, it would seem that the bulk of jointly owned property consists of this sort of property rather than stocks and bonds.

If there are adequate records to solve this problem, there is the larger issue of whether the joint tenants want to split their property. Will they continue to be wedded to the "ours" concept when it is clearly not to their advantage? ${ }^{131}$ The answer, in many cases, will be yes! The senior citizen seeking estate planning counsel is concerned with death far more than the younger taxpayer who is attending to the matter of a will much as he attends to the purchase of a house, an automobile, or life insurance. The older taxpayer will be concerned about putting his affairs in order, but he will clearly want to avoid disrupting established patterns. Splitting up his joimtly held property will have little appeal at a time when he seeks strength and comfort from the concept of family.

Nonetheless, a persuasive case can be nuade for urging the split of jointly held property and the equalization of the taxable estates of liusband and wife. The argunent is expressed not only in terms of tax savings but also in terms of non-tax considerations. In cases where one joint tenant becomes imcoinpetent, the other tenant may be severely restricted in the nuanagement of the jointly held property. The extent of that restriction will depend upon the kind of protection given the mconipetent by the local court. Moreover, the joint tenancy feature will prevent the use of the dispositive provisions of the will of the first spouse to die as a means to protect the surviving joint tenant who may be incompetent. The disadvantages of a legal guardianship of an imcompetent are too well known and too numerous to enumerate here, and one can only speculate about the helplessness engendered by a situation where one joint tenant is legally incompetent and the other joint tenant cannot effectively prevent the jointly held property froin

130. See text accompanying notes 90-101 supra. In the case of other property held as joint tenants with right of survivorship, no gift tax liability will arise if the property is split in proportion to the joint tenants' respective fractional imterests in the property determined by state law. See text accompanying notes 82-86 supra. Where such other property is held as tenants by the entirety, no gift tax will result if the property is split according to actuarially calculated fractions. See text accompanying notes $87-89$ supra.

131. As one commentator has observed:

Simply recommending a division of the joint ownership into proportionate separate pieces will not win acceptance by every chent. In addition to being fraught with complexity and misunderstanding, this approach seems wholly negative to a person seeking constructive alternatives. Riecker, supra note 33, at 819 .

See text accompanying notes 28-34 supra. 
falling subject to the legal guardianship. There is also risk of litigation on the question whether the joint tenant who provided the consideration for the property really intended to give the other joint tenant an interest in the property or whether the joint tenancy was established only for convenience. ${ }^{132}$

\section{Termination of Joint Tenancy in Contemplation of Death \\ A. Estate Planning Possibilities}

A persuasive case can be inade for urging that serious consideration be given to splitting jointly held property in those cases where death is imminent. That is to say that, with one exception to be noted below, transfers in contemplation of death are positively encouraged by the tax law. In fact, the tax savings possibilities here are positively exciting.

The rules are fairly simple. Section $2035^{133}$ requires property transferred in contemplation of death to be included in the transferor's gross estate for federal estate tax purposes at his death. ${ }^{134}$ To the

132. See note 51 supra and accompanying text.

133. Section 2035 provides:

(a) GENERAX RULE.-The value of the gross estate shall include the value of all property ... to the extent of any interest therein of which the decedent has at any time made a transfer (except in case of a bona fide sale for an adequate and full consideration in money or money's worth), by trust or otherwise, in contemplation of his death.

(b) APPLICATION OF GENERAL RULE.-If the decedent within a period of 3 years ending with the date of his death (except in case of a bona fide sale for an adequate and full consideration in money or money's worth) transferred an interest in property, relinquished a power, or exercised or released a general power of appointment, such transfer, relinquishment, exercise or release shall, unless shown to the contrary, be deemed to have been made in contemplation of death within the meaning of this section and sections 2038 and 2041 (relating to revocable transfers and powers of appointment); but no such transfer, relinquishment, exercise, or release made before such 3 year period shall be treated as having been made in contemplation of death.

INT. Rev. CoDe of 1954, \& 2035.

It probably should be noted that involuntary transfers may be deemed transfers in contemplation of death for purposes of section 2035. See City Bank Farmers Trust Co. v. McGowan, 323 U.S. 594 (1945) (transferor institutionalized and court directed transfer of property to presumptive heirs prior to death of transferor).

134. All property included in a decedent's gross estate is valued as of the date of death or as of the alternate valuation date regardless of whether the property was transferred by the decedent during his lifetime. Treas. Reg. $\$ 20.2031-1$ (b) (1954). Valuation problems are occasionally presented when property transferred during lifetime is included in the decedent's gross estate under one of the attribution sections such as section 2035. The appreciation enjoyed by the property while in the hands of the transferee is subject to the estate tax, but care must be taken to exclude the value of additions or improvements made by the transferee. Id. $\$ 20.2035-1(\mathrm{e})$. When cash is the subject matter of the transfer, no valuation problems should be presented. The actual cash transferred (unadorned by any interest earned while in the hands of the transferee) should be included in the gross estate of the transferor. 
extent that federal gift tax has been paid at any time on property included in a decedent's gross estate, the decedent's estate will enjoy a credit against its estate tax liability. ${ }^{135}$ Moreover, the annount of gift tax paid will be removed from the base used in computing the taxable estate of the decedent for purposes of applying the federal estate tax rate schedule! In other words, there is no disadvantage to a transfer in contemplation of death; in fact there may be a benefit. ${ }^{136}$

\section{(1) Joint Tenancy with Right of Survivorship}

There is additional incentive to make transfers of jointly held property in contemplation of death as a result of the restrictive interpretation the courts have given section $2040,{ }^{137}$ the federal estate tax provision which expressly includes jointly held property in the gross estate of the first to die of the co-owners (except to the extent the survivor can establish his contribution). In a series of cases, section $2040^{138}$ has been limited to property which is held in joint tenancy at

135. See INT. Rev. CODE OF 1954, $\$ 2012$. Where the gift tax has not been paid at the time of the donor's death, it may still be claimed as a deduction in computing the donor's taxable estate. Treas. Reg. § 20.2012-1 (a) (1954).

The purpose of the gift tax credit is to prevent the same transfer from being taxed under both the estate and gift taxes. C. Lowndes \& R. KRAMER $\S 20.4$, at 515 . For that reason, the gift tax credit is limited to the lesser of the two taxes. While the gift tax rates are three-fourths of the estate tax rates, see note 125 supra, a donor probably would actually increase his total transfer tax liability if he attempted to transfer all of his property im contemplation of death.

136. Moreover, the property which is subsequently included in the transferor's gross estate as a transfer in contemplation of death will take as its basis, for income tax purposes, the value at which it is included in the decedent's gross estate. See INT. Rev. CODE of 1954 , $\S 1014$. This may be an important benefit where the jointly held property has appreciated.

137. Section 2040 provides:

The value of the gross estate shall include the value of all property to the extent of the interest therein held as joint tenants by the decedent and any other person, or as tenants by the entirety by the decedent and spouse, or deposited, with any person carrying on the banking business, in their joint names and payable to either or the survivor, except such part thereof as may be shown to have originally belonged to such other person and never to have been received or acquired by the latter from the decedent for less than an adequate and full consideration in money or money's worth: Provided, That where such property or any part thereof, or part of the consideration with which such property was acquired, is shown to have been at any time acquired by such other person from the decedent for less than an adequate and full consideration in inoney or money's worth, there shall be excepted only such part of the value of such property as is proportionate to the consideration furnished by such other person: Provided further, That where any property has been acquired by gift, bequest, devise, or inheritance, as a tenancy by the entirety by the decedent and spouse, then to the extent of one-half of the value thereof, or, where so acquired by the decedent and any other person as joint tenants and their interests are not otherwise specified or fixed by law, then to the extent of the value of a fractional part to be determined by dividing the value of the property by the number of joint tenants. Id. \$ 2040 .

138. Textual references to "section -" are references to the indicated sections of the Internal Revenue Code of 1954. 
the death of a co-owner. ${ }^{139}$ Where a joint tenancy has been terminated prior to death, even if in contemplation of death, section 2040 will not be applied. In this kind of case, section 2035 is deemed controlling and the question becoines one of valuing the interest the decedent transferred in contemplation of death. The joint tenancy cases have answered this question, not by reference to the respective contributions of the joint tenants, but by reference to state property law notions. It has been held that each joint tenant has an undivided laalf interest in the jointly held property under state law and, therefore, the only interest the deceased co-owner could have transferred in contemplation of death was his fractional interest.

The landmark decision which gave rise to this restrictive interpretation of section 2040 was Sullivan's Estate v. Commissioner. ${ }^{140}$ In that case the decedent and his wife owned certain property in joint tenancy but transferred a portion of it to their son in contemplation of death. ${ }^{141}$ The Commissioner sought to include the entire value of this property in the decedent's estate under the predecessor of section 2040, but the Ninth Circuit held that only one-half could be included because the decedent had ownership in only one-half to transfer in conteinplation of death:

Under the law of California, one joint tenant cannot dispose of anything more than his own interest in the jointly held property. "During the lives of the tenants, the rules regulating the transfer of their interests are substantially the same, whether they hold in joint tenancy or in common. Neither a joint tenant nor a tenant in common can

139. The following cases involved property held as joint tenants with right of survivorship: United States v. Heasty, 370 F.2d 525 (10th Cir. 1966) (transfer of jointly held property to an irrevocable trust subject to retained life estates); Sullivan's Estate v. Commissioner, 175 F.2d 657 (9th Cir. 1949), rev'g 10 T.C. 961 (1948) (transfer to third party of jointly held property in contemplation of death; split of jointly held property in contemplation of death into tenancy in common); Estate of Don Murillo Brockway, 18 T.C. 488 (1952), aff'd on other grounds, 219 F.2d 400 (9th Cir. 1954) (transfer to third party of jointly held property in contemplation of death). Contra, Harris v. United States, 193 F. Supp. 736 (D. Neb. 1961) (sphit of jointly held property in conteinplation of death into tenancy in common).

See note 143 infra for cases where the same result was reached which involved property held as tenants by the entirety.

140. 175 F.2d 657 (9th Cir. 1949).

141. Id. at 658. The decedent and his wife also made a second transfer of jointly owned property im Sullivan. Property held im joint tenancy was converted into a tenancy in common between the husband and wife. The Ninth Circuit held that even if this transaction were to be construed to be a transfer made in contemplation of death, it was one made for adequate consideration and thus only one-half was includible in the husband's estate. Id. at 659-60; see C. LowNDEs \& R. KRAMER $\$ 11.10$, at 240-41; Riecker, supra note 33, at 824. For criticism of this conclusion, see text accompanying notes 175-76 infra. 
do any act to the prejudice of his co-tenants in their estate." Where a joint tenant has purported to convey more than his interest, his transferee is held to have taken only the interest that could be transferred, i.e., the transferor's share.

It is obvious that the half interest conveyed by the wife was not in contemplation of death. She is still living. ${ }^{142}$

\section{(2) Tenancy by the Entirety}

Sullivan's Estate involved property held as joint tenants with right of survivorship. Other cases have extended the Sullivan rationale to property held as tenants by the entirety; the landmark case was Estate of A. Carl Borner. ${ }^{143}$ In Borner, the Tax Court reasoned as follows:

We agree with petitioner that the rationale of the Sullivan and Brockway cases is applicable here. It is true that these cases involved joint tenancies, while here the property transferred was held in a tenancy by the entireties. Differences do exist between the two estates but such differences are not sufficient to compel unlike tax results under the provisions of section 811 (c). The only difference is a tenancy by the entireties is based on the ancient common law fiction that husband and wife are one, and the right of survivorship cannot be destroyed without mutual consent, while in a joimt tenancy one tenant, by transferring, can destroy the survivorship right. We conclude as a practical matter, the tenancy by entirety and joint tenancies are so inuch alike that the rule applied in the joint tenancy cases should be applied here where the tenancies are by the entirety, which means each tenant owns one-half. This conclusion does not rest upon any peculianities of Pennsylvania property law. Pennsylvania law, while determinative of the nature of the property rights in joint tenancies and tenancies by the entireties, cannot control the application of the Federal tax statutes to such property rights. ${ }^{144}$

On October 6, 1969, the Internal Revenue Service announced its

142. 175 F.2d at 658-59, quoting Stark v. Barrett, 15 Cal. 361, 368 (1860) (citations omitted).

143. 25 T.C. 584 (1955); see Glaser v. United States, 306 F.2d 57 (7th Cir. 1962) (transfer of tenancy by the entirety property to children subject to retained life estates); Baltimore Nat'l Bank v. United States, 136 F. Supp. 642 (D. Md. 1955) (tenancy by the entirety in securities changed to tenancy in common in contemplation of death); Estate of Edward Carnall, 25 T.C. 654 (1955) (tenancy by the entirety in securities changed to tenancy in common in contemplation of death). Contra, Commonwealth Trust Co. v. Driscoll, 50 F. Supp. 949 (W.D. Pa.), aff'd per curiam, 137 F.2d 653 (3d Cir. 1943), cert. denied, 321 U.S. 764 (1944) (transfer in contemplation of death of tenancy by the entirety in real estate to surviving tenant).

144. 25 T.C. at 587-88. 
intention to follow these two lines of cases. ${ }^{145}$ This relatively new policy is a positive inducement to plan transfers of jointly held property in contemplation of death at least in the following two cases: (1) where there is no evidence to establish the respective contributions of the joint tenants in the jointly held property; and (2) where the joint owner whose death is imminent has provided more than fifty percent of the contribution to the jointly held property. In the case where the death of the joint tenant making the smaller contribution is imminent, it inay be ill-advised to split the jointly held property between the spouses or make any other transfers of the jointly held property in contemplation of death if the only goal is to minimize the taxable estate of the first to die. Since that person's contribution is less than fifty percent of the total contributions to the jointly held property, the only portion of the jointly held property that will be included in her estate at her death if the property remains jointly held is that portion attributable to her contribution. ${ }^{146}$ If the joint tenancy is terminated in contemplation of death, however, it is probable that her actual contribution to the jointly held property will be disregarded and one-half of the property will be included in her gross estate for federal estate tax purposes. ${ }^{147}$ Sullivan and its progeny would seein to provide the

145. 1969-2 CuM. BuLL. Xxiii.

146. See INT. Rev. CODE of 1954, § 2040.

147. See Miller v. Uuited States, 325 F. Supp. 1287 (E.D. Pa. 1971); Estate of Koussevitsky, 5 T.C. 650 (1945). See text accompanying notes 191-92 infra. In Miller, the court held that one-half the property subject to an irrevocable trust in which the decedent had a life estate should be included in her gross estate. The decedent and her husband had established the trust many years before her death. Although the property placed in the trust had been acquired by the decedent's husband from his separate property, it had been held by the decedent and her husband as tenants by the entirety prior to the establishment of the trust. In finding for the government, the court reasoned that the decedent had transferred to the trust an interest in property given her by local law and retained a life estate in the transferred property.

Koussevitsky was much more complicated but eventually was decided for the taxpayer. It is probably of little precedential value since it was decided before Sullivan and its progeny, but the court's analysis of several complex issues is interesting. In this case, Mrs. Koussevitsky transferred property shortly before her death from her wame into that of herself and her husband as joint tenants with right of survivorship. The property had originally been given to Mrs. Koussevitsky by her husband. The government relied upon a number of different theories in attempting to include the jointly held property in Mrs. Konssevitsky's estate. It was first argued that the property belonged to her at the time she created the joint tenancy and therefore she should be deemed to have furnished all the consideration for the property which became jointly held. The government, however, conceded that this position was incompatible with that which it would have assumed had the husband died first. It was acknowledged that had the husbaud died first, section 2040 wonld have required the government to disregard state property law conceptions and include all the jointly held property in his gross estate since he provided all the consideration for the jomtly held property. 
government with an opportunity, in the name of consistency, to disregard the contribution rules of section 2040 and eniphasize that the decedent transferred in conteniplation of death the interest local law gave her in the jointly held property. ${ }^{148}$

It inust be eniphasized, however, that even in those cases where a terinination of the joint tenancy in conteniplation of death will bring about a greater immediate federal estate tax bill, it will probably continue to be advisable to bring about such terminations. Such a lifetime sphit will enable the spouses to equalize their estates and the first spouse to die will be able to create a trust of a portion of the jointly held property for the survivor and thereby keep the jointly held property out of the survivor's gross estate. ${ }^{149}$

The government then argued that Mrs. Koussevitsky made a lifetime transfer and retained a life estate when she placed her property in the joint tenancy with her husband. It also argued that she made a transfer revocable until her death. On either of these theories, it was alleged that the jointly held property should be included in Mrs. Koussevitsky's gross estate. The court rejected these arguments after finding that Congress legislated specifically with respect to jointly held property and that the more specific section controlled. Since the property was not included in her gross estate as jointly held property, the court held that it could not be included under any other section unless that section was even more specific. The government then argued that the transfer was made in contemplation of death and argued that this section of the Code was more specific than that provided for joint tenancies. The court agreed in principle but determined as a factual matter that Mrs. Koussevitsky did not create the joint tenancy in contemplation of death.

Is there any inconsistency in Koussevitsky? On the one hand, the court said that had Mr. Koussevitsky died first, it would have traced the consideration for the jointly held property to him and included the jointly held property in his gross estate. For that reason, the court then concluded that it would be inconsistent to include the jointly held property in Mrs. Koussevitsky's estate on the ground that she created the joint tenancy with property that had belonged to her but which had originally been a gift from her husband. Essentially the court was saying that the government could not, on one hand, say the property belonged to Mrs. Koussevitsky for purposes of taxing it to her and, on the other hand, trace through her if her husband were the first to die for purposes of taxing it to him. After having expressed concern about an inconsistent application of the taxing statutes, the court turned around and agreed in principle that the jointly held property could be included in Mrs. Koussevitsky's gross estate if she had transferred it in contemplation of death. Thus the court first found that the federal estate tax provision on joint tenancies compelled it to ignore state-created property rights (the fact that the property actually belonged to Mrs. Koussevitsky), but it then concluded that state-created property interests could have carried the day for the government after all.

148. See cases collected in notes 139,143 supra. Where the property is held as joint tenants with right of survivorship, she will be deemed to have transferred a onehalf interest in the jomtly held property. Moreover, the same rule will apply to tenancy by the entirety property transferred in contemplation of death given the tendency of the courts (and the government since 1969, see note 145 supra and accompanying text) to disregard state property law distinctions between the two estates.

149. See notes 64-79 supra and accompanying text. 


\section{(3) Joint Bank Accounts}

There also continues to be some uncertainty about the treatment of joint bank accounts transferred in contemplation of death. Joint bank accounts are different froin other kinds of jointly held property in that, practically speaking, under state law each co-owner's interest in the account is limited to the proportion of the account attributable to his deposits. ${ }^{150}$ Simce the courts appear to be deferring to state law concepts of ownership in resolving the contemplation of death issues for transfers of other types of jointly held property, ${ }^{151}$ one can only speculate whether the rule announced as applicable to all other jointly held property will apply to the joint bank account. It is certainly arguable that where joint bank accounts are transferred in contemplation of death, the value of the property transferred when included in the decedent's gross estate will be the value of the property for federal gift tax purposes. ${ }^{152}$ The value of the property for federal gift tax purposes is the amount withdrawn by a co-owner in excess of the portion of the account attributable to his deposit. ${ }^{153}$

\section{B. Policy Considerations}

Notwithstanding the acquiescence of the Internal Revenue Service in the Sullivan and Borner lines of decisions, it has been argued that the cases reach "an undesirable result" and do not "represent a necessary construction of the statute."154 The restrictive interpretation given to section 2040-that it applies only to property which is jointly held at the death of a co-owner-undermines the purpose of section

150. See note 51 supra and accompanying text. This certainly is the view taken by the government. See Treas. Reg. \$ 25.2511-1(h)(4) (1954) (example).

151. See cases collected in notes 139,143 supra.

152. There are several cases which contradict this position. They are frequently cited as holding that when a joint bank account is transferred in contemplation of death, the entire anount transferred (not merely one-half) will be included in the estate of the decedent in cases where he furnished all the consideration. See Estate of Frank K. Sulkian, 10 T.C. 961 (1948), rev'd on other grounds, 175 F.2d 657 (9th Cir. 1949); Estate of Henry Wilson, 2 T.C. 1059 (1943); Estate of Harold W. Grant, 1 T.C. 731 (1943) (dictum); Effland, supra note 3, at 532-33.

For example, $H$ and $W$ have a jomt bank account containing $\$ 4,000$. $H$ coutributed $\$ 3,000$ and $W \$ 1,000$. In contemplation of $H$ 's death, $H$ and $W$ transfer the balance of the account to an account standing in W's name alone. In this case $H$ will probably be deemed to have transferred $\$ 3,000$ in contemplation of death. On the other hand, if jointly held property other than a bank account were transferred, $H$ could be deemed to have transferred only $\$ 2,000$ in contemplation of death.

- 153. See Treas. Reg. \$ 25.2511-1(h) (4) (1954) (example).

154. C. LOWNDES \& R. KRAMER $\$ 11.10$, at 241; see Note, Joint Tenancy and Estate Tax Avoidance: A Widening Loophole for Transfers in Contemplation of Deatl, 66 YALE L.J. 142, 146-48 (1956). 
2035 which is to prevent the depletion of a decedent's taxable estate through transfers in conteinplation of death. ${ }^{155}$ The rationale underlying Sullivan and its progeny was that the decedent only owned, and therefore only transferred, one-half of the property under state property law concepts and thus could only transfer that amount in contenplation of death. ${ }^{156}$ But, as one commentator has observed, "the concept of 'ownership' for estate tax purposes is based on economic contribution and control rather than the legal abstraction of 'title.' "157 Furthermore, section 2035 has been given an expansive interpretation where sections other than section 2040 of the federal estate tax scheine have been involved. ${ }^{158}$ Examples of two situations wherein section 2035 has been utilized to tax property transferred in contemplation of death as part of the decedent's estate as if no transfer had been made will be set forth for purposes of illustration.

The first example is drawn froin the case of United States $v$. Allen, ${ }^{159}$ in which the Tenth Circuit refused to permit a decedent's estate to be depleted through the sale, in contemplation of death, of a retained life interest. Mrs. Allen had transferred property some years before her death and had retained the incoine from the property for her life. Within three years of her death, she transferred her retamed life estate in exchange for consideration worth more than the actuarially determined fair market value of her life interest. Hence, at her death Mrs. Allen had no interest in the property under state law. The court not only held this transfer to have been made in contemplation of death but also held that it was inade for less than adequate and full consideration in money or money's worth. ${ }^{\mathbf{1 6 0}}$ The court included in her gross estate the value of the transferred corpus in which Mrs. Allen had retained a life estate and allowed as an offset the consideration she had received in exchange for the life interest. The court reasoned

155. See United States v. Wells, 283 U.S. 102 (1931); C. LOWNDES \& R. KRAMER $\S 5.1$. In commenting upon its decision, regarding the gift of jointly held property, in Estate of Don Murillo Brockway, 18 T.C. 488 (1952), aff'd, 219 F.2d 400 (9th Cir. 1954), the Tax Court said: "If this result [laid down by Sullivan] is contrary to the basic purpose of the estate tax statute and there is a loophole in section 811(c) [predecessor of section 2035], the reınedy lies with Congress." Id. at 499.

156. See notes 140-42 supra and accompanying text.

157. Note, supra note 154, at 147 (footnotes omitted and emphasis supplied).

158. The regulations discuss the application of other sections of the estate tax code provisions to section 2035 and, by omission, recognize the nonapplicability of section 2040 to section 2035. Treas. Reg. \& 20.2035-1(b) (1954).

159. 293 F.2d 916 (10th Cir.), cert. denied, 368 U.S. 944 (1961).

160. Id. at 917-18. Section 2035 includes property to the extent the decedent has made a transfer in conteinplation of death "except in case of a bona fide sale for an adequate and full consideration in money or inoney's worth . . ." INT. Rev. CoDE of $1954, \S 2035$ (a). 
that if she had not sold the life estate in contemplation of death, the entire corpus would have been included in her gross estate because she had retained a life estate in the property when she originally transferred the corpus. In order to achieve the purpose of section 2035, which is to prevent depletion of the estate, the court disregarded the fact that the life interest had been transferred before death. ${ }^{161}$

The second exainple illustrating the expansive interpretation given to section 2035 is taken from the tendency of courts to look beyond state law determinations when including life insurance in a decedent's estate. Under present estate tax law, the proceeds of life insurance will be included in the insured's gross estate only if (1) the proceeds are receivable by his executor or (2) the insured had any of the incidents of ownership at his death. ${ }^{162}$ Whether or not the insured paid the premiums to keep the insurance in force is now irrelevant under the Internal Revenue Code as to whether the proceeds are includible in his gross estate. Congress abandoned the premiums-paid standard in 1954, and ever since the Internal Revenue Service has been administratively chipping away at this congressional pronouncement. The Service had imitially contended that, while premiums payments could not be used to determine includibility of insurance proceeds in the insured's gross estate as a general rule, if the premiuns were paid in contemplation of death, the proceeds attributable to those premium payments were includible under section $2035 .^{163}$ The courts rejected this blanket rule of inclusion on the ground that it was in effect a return to the old premium payment test, but the decisions did allow the premiums themselves to be included in the insured's gross estate where he paid the premiums in contemplation of death. ${ }^{164}$ But other more

161. 293 F.2d at 918, citing Lowndes, Cutting the "Strings" on Inter Vivos Transfens in Contemplation of Death, 43 MiNN. L. Rev. 57, 71 (1958):

[T]he determination of what interest is transferred in contemplation of death and of what is adequate consideration to prevent a transfer in contemplation of death from being taxable, should be made on the basis of the tax effect of the transfer and the effect of the consideration on the transferor's taxable estate, rather than by the comparatively irrelevant rules of property law.

In spite of the seemingly broad application of the rationale of Allen, the Tenth Circuit held in a subsequent case that Allen was restricted to its facts. United States $v$. Heasty, 370 F.2d 525 (10th Cir. 1966); see Schwartz, Estate Tax Aspects of Joint Tenancies and Tenancies by the Entirety, 1970 TAXATION AND. Estate Planning SXMPOSIUM 90, 103.

162. INT. REv. CODE OF 1954, § 2042.

163. Rev. Rul. 67-463, 1967-2 Cum. Bunc. 327, revoked in part, Rev. Rul. 71-497, 1971-2 CuM. BuLL. 329.

164. First Nat'l Bank v. United States, 423 F.2d 1286 (5th Cir. 1970); Estate of Inez G. Colemau, 52 T.C. 921 (1969). In 1971, the Internal Revenue Service revoked Rev. Rul. 67-463 in part. Rev. Rul. 71-497, 1971-2 CUM. BULL. 329. 
recent decisions have given more encouragement to the Service. ${ }^{165}$ It now appears clear that the proceeds of insurance will be included in the insured's gross estate where the policy was taken out (or renewed in the case of term insurance) within three years of the insured's death and the imsured paid the premiums or provided the funds from which some other person paid the premiums. ${ }^{166}$ The fact that the insured had none of the incidents of ownership and that the proceeds were not receivable by his estate appears to be irrelevant.

These examples suggest a willingness on the part of the courts to give an expansive interpretation to the inclusion aspects of section 2035. Thus, it is surprising to find that transfers of jointly held property in contemplation of death enjoy such favorable tax treatment. Regrettably, there is nothing im the legislative history of the estate tax provision taxing jointly held property at death to indicate congressional intent regarding treatment of transfers of jointly held property in conteinplation of death. ${ }^{167}$ Given the uncertain doctrimal foundations of the favorable treatment accorded jointly held property in this context, estate planners might be well advised not to rely too heavily on the continued vitality of that treatment in long-term planning.

\section{Some Speculative Suggestions: Tenancies by the Entirety}

\section{(1) Criticism of Borner}

It is apparent that, notwithstanding the favorable tax advantages which Sullivan and Borner present to estate planners, those two decisions are subject to some criticism on the ground that they permit a

165. See, e.g., First Nat'l Bank v. Slade, 488 F.2d 575 (9th Cir. 1974); Detroit Bank \& Trust Co. v. United States, 467 F.2d 964 (6th Cir. 1972), cert. denied, 410 U.S. 929 (1973); Bel v. United States, 452 F.2d 683 (5th Cir. 1971).

166. The position of the Service is presently this: (1) With respect to policies of life insurance (other than one year term insurance) transferred by the insured more than three years before his death, only the premiuns paid within three years of his death will be included in his gross estate as transfers in contemplation of death; (2) as to one year term insurance policies, the entire proceeds will be included in the insured's gross estate where he pays the premiuns even in those cases where ownership was transferred more than three years before the death of the insured. Rev. Rul. 71497, 1971-2 CuM. BuLl. 329.

167. The Committee Reports on the Revenue Acts from 1916 to 1939 do not deal with joint property as affected by transfers in contemplation of death. The reports for the acts froin 1916 to 1938 are found in 1939-1 Cum. Buld. (Pt. 2) 101, 127, 151, $179,198-200,229,261,289,308,324,338,432$, 489-94, 530-36, 581-82, 620-21, 77072, 786, 807-09. The Interual Revenue Code of 1939 made no change in existing law. 1939-2 Cum. Bull. 532, 533. Similarly the Internal Revenue Code of 1954 made no substantive change in existing law when promulgating sections 2035 and 2040. 3 U.S. CODE Cong. \& AD. News 4459, 5116 (1954). 
decedent to deplete his estate by terminating a joint tenancy or a tenancy by the entirety in contemplation of death. ${ }^{168}$ The Borner decision is subject to even further criticism because, while purporting to follow Sullivan, it ignores the fundamental underpinning of that casethat property law concepts govern the interest which can be included in a decedent's gross estate under section 2035..$^{160}$

If you are going to exclude part of the common property from the estate tax when it is transferred in contemplation of death by the tenant who paid the entire consideration for the property, because of technical conceptions of the property law that the transferor only transferred the interest which he owned in the property, it would seem only fitting to give due attention to the interest whieh the tenant owned and to the fact that a tenant by the entirety, who has no right to sever the tenaney, owns an entirely different interest in the common property than a joint tenant, who has a right of severance. ${ }^{170}$

While there inay be some dispute as to how the interest transferred by the decedent in Borner should be valued, it is at least clear that the amount actually included im his estate (one-half) in no way represents the interest transferred under property law concepts.

\section{(2) Transfers for Adequate and Full Consideration}

Perhaps this criticism could be turned into an even bigger tax "break" in cases where property held as tenants by the entirety is transferred to third parties in contemplation of death. Since transfers for adequate and full consideration in money or money's worth ${ }^{171}$ cannot be taxed under section 2035 as transfers in contemplation of death, it could be argued, for example, that the inutual relinquishment by the tenants by the entirety of their respective interests in the whole at the time of the conveyance constitutes adequate and full consideration in money or money's worth. ${ }^{172}$ Each tenant by the entirety has an interest in the whole, and usually neither tenant can unilaterally sever the tenancy. Thus, upon termination, each tenant will have given up his right to enjoy the entire premises in exchange for the other tenant giving up his right in the whole. ${ }^{173}$

168. See notes 154-67 supra and accompanying text.

169. See notes 140-42 supra and accompanying text.

170. C. Lowndes \& R. KRAMER § 11.10, at 244; see Note, supra note 154, at 145.

171. This term has enjoyed a rather precise definition. See Treas. Reg. $\$ 20.2043$ 1(a) (1954).

172. Id. Even if the interests relinquished were not equivalents, the regulation provides that "only the excess of the fair market value of the property . . . over the price received by the decedent is included in ascertaining the value of his gross estate." Id.

173. This argumeut would have no purpose if made where spouses have divided 
In those jurisdictions where the wife's interest in a tenancy by the entirety does not include a right to income or possession, the termination of the tenancy means that she has relinquished a lesser interest, namely, the right to possibly survive the other tenant by the entirety and enjoy the entire premises. Nevertheless, this possibility of survival can be actuarially valued for purposes of the adequate and full consideration in inoney or money's worth standard. ${ }^{174}$

It should also be clear, however, that the adequate and full consideration question has no place in a discussion of death tax consequences that result from a termination in contemplation of death of a joint tenancy with right of survivorship. Unfortunately the court in Sullivan muddied the waters by engaging in just such a discussion:

If, on the other hand, the contract be construed to involve a transfer, it was a bona fide transfer for money's worth because the younger wife's joint interest transferred to the older husband is worth at least as inuch as the husband's interest transferred to "her."

The Commissioner also contends that it was not bona fide because the negotiations between the spouses were not at "arms' length." There is no evidence to support such a contention. The actual contract is such a fair one to each, that it is of the sort which would be the result of arms' length bargaining. ${ }^{175}$

jointly held property among themselves in contemplation of death even if the split was into other than equal shares. In those cases where the spouses take equal shares of the jointly held property at termination of the joint ownership arrangement, the decedent will include one-half the property in his gross estate as a transfer in contemplation of death, see note 143 supra and accompanying text, or on alternate grounds as probate property. See INT. REv. CoDE of 1954 , \$ 2033. Similarly, if the decedent acquired more than one-half of the property upon termination of joint ownership, the portion he owned at his death will be included in the gross estate because it is that portion which passes at his death. Id. In such a case, the transfer in contemplation of death principle would not be argued by the government because it would cause a lesser amount (only one-half) of the jointly held property to be included in his gross estate. On the other hand, if the joint ownership arrangement is terminated and the surviving spouse, for example, takes all of the jointly held property, only one-half of that property will be included in the decedent's estate as a transfer in contemplation of death. See notes 139-43 supra and accompanying text.

However, it must be noted that the argument made in text may have application in cases where the jointly held property is transferred to an irrevocable trust which gives the trustee complete discretion over all distributions of principal and income. See note 199 infra and accompanying text.

174. Cf. Rev. Rul. 69-505, 1969-2 Cum. Buls. 179, discussed in note 205 infra.

175. Sullivan's Estate v. Commissioner, 175 F.2d 657, 659 (9th Cir. 1949). It has been suggested that the transfer for consideration argument has merit. Effland, supra note 3 at 532 . 
The only possible consideration furnished in Sullivan was the wife's consent to transfer her fractional interest in the jointly held property in exchange for her husband's agreennent to transfer his fractional interest in the same property. Her consent was consideration only to the extent a peppercorn is consideration at common law. No money value could be attached to it as contemplated by the adequate and full consideration in money or money's worth standard. ${ }^{176}$

\section{(3) Actuarial Valuation of Transfers in Contemplation of Death}

Another argument which the taxpayer might use to carve out some additional benefit froin transferring his tenancy by the entirety in contemplation of death is, first, to acknowledge that his interest and that of his spouse in the tenancy by the entirety can be valued actuarially, and then, to argue that the rules employed in valuing lifetime gifts of tenancy by the entirety property ${ }^{177}$ should be used in determining the value of the interest he transferred in contemplation of death. Assume a taxpayer was intent on transferring all of his interest in his tenancy by the entirety property to his spouse before his death. If he was forty-five at the time of the transfer and she was forty, and the property had a value of $\$ 10,000$ both at the time of transfer and also at the date of his death, the following computation indicates that $\$ 4,291.10$ would be subject to federal gift tax. It would seem equally appropriate to suggest that the value of his gift in contemplation of death was $\$ 4,291.10$ rather than one-half the value of the transferred property as it would be valued under existing law. ${ }^{178}$

Value of property transferred $\$ 10,000.00$

Less: Value of wife's interest in the property $\$ 10,000 \times .57089)^{170}$ $5,708.90$

Value of gift for federal gift tax purposes and

value of gift in contemplation of death $\overline{\$ 4,291.10}$

This is really the actuarially determined value of the interest in the property which he transferred in contemplation of death. ${ }^{180}$ The balance of the property was already vested in the wife.

176. See note 171 supra.

177. See notes $87-89$ supra and accompanying text.

178. See notes 139,143 supra.

179. For actuarial factors, see IRS PUBLICATION 723A, SUPPLEMENT 1 (4-71), supra note 63.

180. Lowndes and Kramer snggest this result in commenting upon the conduct of the Borner case before the Tax Court by Borner's executrix. The Commissioner had sought to include all of the tenancy by the entirety property in the decedent's estate, 


\section{(4) Section 2515 Property}

These arguments (based on actuarial valuations and transfers for consideration) should also be available even in those cases where real property is involved and the taxpayer has elected under the authority of section 2515 not to file gift tax returns at the time the tenancy by the entirety was created. In determining what interest a decedent has transferred in contemplation of death, the government looks to local property law concepts. The fact that no gift tax was paid when the tenancy by the entirety was created is a neutral factor in this determination. ${ }^{181}$ Thus, the adequate and full consideration argument and the actuarial value argument outlined above could be inade with respect to section 2515 property transferred in contemplation of death.

Perhaps there is another question with respect to section 2515 property. No court has yet considered whether Sullivan and its progeny apply to section 2515 cases. Technically, section 2515 property which is transferred in contemplation of death should enjoy the same treatment for federal estate tax purposes as other jointly held property transferred in contemplation of death. ${ }^{182}$ Nonetheless, some court confronted by section 2515 property transferred in contemplation of

and in response the executrix merely argued that one-half should be excluded, "instead of some different and larger anount on the theory that the husband had transferred only the actuarial value of his interest in the property." C. LOWNDES \& $\mathrm{R}$. KRAMER $\$ 11.10$, at 243. Expressed another way:

Although the Tax Court said in the Borner case that there was no difference between a tenancy by the entirety and a joint tenancy as far as the estate tax on the transfer of a tenant's interest in contemplation of death is concerned, it might be argued that all that the court actually held was that since the decedent's executrix only sought to exclude half of the common property from his gross estate, it was not up to the court to exclude more than this. Id. (Emphasis in original.)

Perhaps it would be appropriate to argue that the decedent's actual physical condition ought to be considered in determining the interest in the jointly held property that was transferred at death. The government has made such a proposal in connection with the valuation of life estates. See Rev. Rul. 66-307, 1966-2 CuM. BurL. 429.

181. It should be noted, however, that a transfer in contemplation of death of section 2515 property may actually increase the total cost of transferring this property. In the case where the decedent terminates the section 2515 joint tenancy in contemplation of death by transferring his interest in the joint tenancy to his spouse, he will incur federal gift tax liability to the extent the value of the property exceeds the value of the portion of the tenancy attributed to the spouse's contribution. If she made no contribution, the full value of the entire property will constitute a taxable gift to her. While a credit for gift taxes paid will be available to the decedent's estate under section 2012, the credit is available only with respect to gift taxes paid on property included in the decedent's estate. Under this actuarial value rule of inclusion (or, for that matter, under Sullivan and its progeny), it is possible that the decedent's estate may not enjoy credit for all the federal gift tax paid when the property was transferred in contemplation of death. See C. LowNDES \& R. KRAMER $\$ 20.4$, at 518-19.

182. See notes 139,143 supra. 
death may be tempted to analogize to joint bank accounts ${ }^{183}$ and hold that the full value of the section 2515 property transferred in contemplation of death should be included in the gross estate of the decedent.

\section{(5) Conclusion}

It inust be einphasized that the method of evaluation applied in the Borner case is still being followed and the Service has acquiesced therein. Thus, as logically appealing as the criticism of that case may appear, it would be unwise for estate planners to rely upon that criticism.

\section{JoInt Tenancies AND TRUSTS}

Trusts have come to be virtually synonymous with estate planning. They are einployed in almost every estate plan for both tax and nontax reasons. In planning for jointly held property, however, the trust has limited utility so long as the property remains in joint ownership.

It would seem that the only reason for employing trusts to hold jointly owned property would be for purposes of providing property management during the joint lifetimes of the co-owners. Such trusts should have appeal only in those cases where the co-owners are reluctant to bring about a lifetime split of the property and insist upon retention of joint beneficial interests in their property. Property inanageinent can be an important consideration in such cases as inflationary pressures intensify. Increasing longevity inay heighten fears of senility and other mental or physical disability. Where these considerations are present, a trust is clearly preferable to the agency or custody account because the trust may provide for the ultimate disposition of the propenty and provide protection against incompetency, as well as provide current professional manageinent.

Taxpayers have, on occasion, transferred jointly held property directly into irrevocable trusts, but it is fairly clear that little is to be accoinplished in the ordinary case by such transfers. ${ }^{184}$ While there are soine tax advantages to such transfers, even inore significant tax advantages can be obtained if the spouses equalize their respective estates and terminate such joint tenancy arrangeinents. ${ }^{185}$ At that point the spouses can then employ a revocable trust device as both a management and dispositive vehicle for their respective estates. ${ }^{180}$

183. See notes 90-91 supra and accompanying text.

184. See notes 190-200 infra and accompanying text.

185. See notes 64-79 supra and accompanying text.

186. See notes $198-99$ infra and accompanying text. 
On the other hand, where revocable trusts have been employed to hold jointly held property, the tax consequences have been unpredictable. ${ }^{187}$ Nevertheless, the revocable trust has appeal as a property management device even for property presently jointly held, and if the trust agreement is properly drafted, it may be possible to obtain some tax advantage froin such a trust. In order to enjoy any tax advantage, however, the trust would have to become partially irrevocable at the death of the first joint tenant to die. ${ }^{188}$ The portion that becomes irrevocable would be held for the benefit of the survivor for life, and, under a properly drafted agreement, the property subject to the irrevocable portion of the trust would be excluded from the survivor's gross estate. ${ }^{189}$ To the extent that co-owners are reluctant to equalize their estates, the partially irrevocable trust has distinct appeal.

The irrevocable trust will be discussed first, followed by the revocable trust, and, finally, the partially irrevocable trust.

\section{A. The Irrevocable Trust}

\section{(1) Estate Tax Consequences}

While there are many reasons why a taxpayer would want to establish an irrevocable trust, the fact that he has jointly held property is a neutral factor. There appear to have been only two litigated cases involving a transfer of jointly held property to an irrevocable trust, and one of the cases involved a transfer in contemplation of death. ${ }^{190}$ Nonetheless, the estate consequences of such transfers are clearly predictable. Where jointly held property is transferred to an irrevocable trust and the transferors retain joimt life estates in the trust, one-half of the trust property will be included in the estate of the first of the joint owners to die ${ }^{191}$ even if the first spouse to die made no contribution to the

187. See notes 214-33 infra and accompanying text.

188. See notes $236-47$ infra and accompanying text.

189. See notes 236-84 infra and accompanying text.

190. Miller v. Umited States, 325 F. Supp. 1287 (E.D. Pa. 1971), discussed in note 147 supra; Estate of A. Carl Borner, 25 T.C. 584 (1955) (transfer im contemplation of death), discussed in text accompanying note 144 supra.

191. See Rev. Rul. 69-577, 1969-2 CuM. Bull. 173; cf. United States v. Heasty, 370 F.2d 525 (10th Cir. 1966) (transfer of joint tenancy with right of survivorship property to children and grandchildren subject to retained life estate); Glaser v. United States, 306 F.2d 57 (7th Cir. 1962) (transfer of tenancy by the entirety property to children subject to retained life estate). In Heasty the court explained its decision thusly:

[S]ection 2040 has no application to a case fike this because after the husband and wife took the property as joint tenants there was another transfer .... Each spouse individually conveyed sone interest to their [sic] children and grandchildren. Whatever law we apply to this case, we cannot say that the wife had no interest to convey because she did have; and she did 
jointly held property. ${ }^{192}$ This result can be explained on the grounds that each spouse has an interest in the property under state law, ${ }^{103}$ and it is that interest which has been conveyed in trust subject to retained joint life estates. ${ }^{194}$ From the taxpayer's standpoint this result is preferable to having all of the jointly held property included in the estate of the first of the joint tenants to die, which would have been the result if the transfers in trust had not been inade. ${ }^{195}$

Perhaps this reason inotivated the transfers. If so, it would seem that the respective taxpayers would have been better advised to have split their jointly owned property between theinselves during their joint lifetimes in such a way as to equalize their estates. ${ }^{100}$ Each of the taxpayers could then have created a trust (by will, for exannle) for his surviving spouse, giving her the income for life with remainder as she may appoint among a limited class of persons. ${ }^{197}$ Like the irrevocable trust, this scheme will keep the property included in the estate of the first to die out of the surviving spouse's gross estate for federal estate tax purposes. In addition, it has several advantages over an irrevocable trust created by the spouses during their joint lifetime. If their estates are equalized, for example:

a. Each spouse could enjoy unfettered dominion and control over half of the property for life without the restrictions inherent in any irrevocable trust.

b. When the first spouse dies, only one-half of the combined estates of the spouses would becoine irrevocable. Thus, the survivor would retain absolute control over his half of the property for the rest of his life.

Perhaps another reason for establishing an irrevocable trust is to obtain professional manageinent for the jointly held property. If that is the case, the client should still be advised to split his jointly

convey it. She transferred a one-half "interest" in the property. The husband cannot be said to have transferred that "interest". They cannot both own it. . . The "interest" contemplated by section 2036 must, in a case like the one at bar, be determined according to the state law. 370 F.2d at 528-29.

In Heasty and Glaser, the respective courts rejected all efforts by the government to include all the property that was once jointly held in the estate of the co-owner who had provided all of the consideration for the property. Each court reasoned that section 2040 was limited in application to property held jointly at the time of death and that it would not otherwise be applied.

192. See Miller v. United States, 325 F. Supp. 1287 (E.D. Pa. 1971).

193. See notes 50, 57-63 supra and accompanying text.

194. See note 191 supra.

195. See INT. REv. Code of 1954, § 2040.

196. See notes 64-70 supra and accompanying text.

197. See notes 68-70 supra and accompanying text. 
held property so as to equalize his estate and that of his spouse and then establish a trust for his post-split share. Such a trust could either be revocable or irrevocable depending upon the client's objectives. If the trust is irrevocable and the chent retains a life estate in the trust property, it would clearly not have any tax advantage over a revocable trust. ${ }^{198}$ However, if the client is willing to commit all trust distributions of principal and income to the discretion of the trustee and retain no right to any of the trust property, use of an irrevocable trust would mean that no part of the trust property would be included in his or her gross estate for federal estate tax purposes. ${ }^{199}$ In some cases this feature could be a substantial advantage and a real inducement to establish this kind of irrevocable trust.

With respect to non-tax considerations, the irrevocable trust would seein to be distinctly disadvantageous relative to a revocable trust in teruns of loss of flexibility. ${ }^{200}$ By that it is meant that neither spouse can ever change the trust to meet changing conditions. This is a high price to pay where there does not appear to be any special benefit to be obtained.

\section{(2) Gift Tax Consequences}

While it is relatively easy to generalize about the estate tax consequences of establishing an irrevocable trust for jointly held property, similar generalization is not possible with respect to federal gift tax consequences. These can only be considered in terms of the kinds of property subject to the gift; when the property was acquired; and whether it is held as tenants by the entirety or as joint tenants with

198. In either case the trust property would be included in the settlor's gross estate at his death. See INT. REv. CoDE of 1954, $\$$ 2036, 2038. Nor would it be possible to obtain any tax benefits by having each spouse create a trust (revocable or irrevocable) for the other spouse for that spouse's lifetime. See United States v. Grace, 395 U.S. 316 (1969).

In cases where the trust is already irrevocable but subject to retained life estates in the settlors, it nuay be possible for the settlors (or one of then) to release their respective life estates in the trust and thereby remove their portion of the trust property from their respective gross estates. What little authority there is available on this point is confusing. See United States v. Allen, 293 F.2d 916, 918 (10th Cir.) (concurring opmion), cert. denied, 368 U.S. 944 (1961). But see Burrill v. Shaughnessy, 71 F. Supp. 99 (N.D.N.Y. 1947). The Internal Revenue Code does not seem to contemplate the release of a retained life estate although it provides for the relinquishment (in contemplation of death) of a power to revoke, alter, amend, modify or terminate a trust. Compare INT. Rev. CODE of 1954, § 2036 with id. $\$ 2038$.

199. See notes 274-84 infra and accoinpanying text.

200. See Sargeut, Should a Trust be Irrevocable?, 4 Reat Property, Probate \& TRUST J. 176, 180-81 (1969). 
right of survivorship. ${ }^{201}$ Assume, for example, that on December 31, 1973, $\mathrm{H}$ and $\mathrm{W}$ established an irrevocable trust which provides that they are each to have equal rights in the trust income for their joint lives and that, after the death of one of thein, the survivor is to receive all the trust income. The trust is to terminate at the death of the survivor of $\mathrm{H}$ and $\mathrm{W}$ and the trust property is to be distributed to their child, C. Assume $\mathrm{H}$ and $\mathrm{W}$ are fifty and forty-seven respectively at the time the trust is established.

Careful analysis indicates that the following property interests have been created in the trust:

a. A vested equitable life estate for $\mathrm{H}$ in one-half of the trust incoine.

b. A vested equitable life estate for $W$ in one-half of the trust income.

c. A contingent equitable life estate for $\mathrm{H}$ in W's share of the income if $W$ predeceases $H$.

d. A contingent equitable life estate for W in H's share of the income if $\mathrm{H}$ predeceases $\mathrm{W}$.

e. A vested remainder in fee for $C$.

At the time the trust was established, $\mathrm{H}$ and $\mathrm{W}$ made the following transfers to the trust. These transfers illustrate the categories into which jointly held property can be grouped for federal gift tax purposes.

\section{Example 1}

$\mathrm{H}$ contributed all the funds to purchase common stock in $\mathrm{ABC}$ corporation which is now worth $\$ 20,000$ and is held by $\mathrm{H}$ and $\mathrm{W}$ as joint tenants with right of survivorship. The stock is transferred to $\mathrm{H}$ and W's irrevocable trust at the time it is established.

In this case $\mathrm{H}$ will be deemed to have made a taxable gift of one-half of the property less the actuarially determined value of the life estate that he has retained in the property. ${ }^{202}$ H's gift is to $\mathrm{C}$, who gets the remainder interest, and to $\mathrm{W}$, who gets a contingent interest in H's

201. In analyzing the gift tax cost of any proposed transaction, one must consider the $\$ 30,000$ lifetime exemption, the $\$ 3,000$ per donee per year exclusion, the gift tax marital deduction, and the gift splitting provisions. See notes 125-28 supra and accompanying text. The $\$ 30,000$ lifetime exemption particularly encourages lifetime transfers because it is lost unless exhausted before death.

202. See Rev. Rul. 69-505, 1969-2 CuM. Bull. 179 (presenting facts upon which this example is based). The tables to be used in determining the present worth of a life interest are found in Treas. Reg. $\$ 25.2512-9$ (f) (1970). However, at the time of the issuance of the Ruling, the tables in Treas. Reg. $\S 25.2512-5(f)$ (1954) were in effect. 
half of the income if $\mathrm{H}$ predeceases $\mathrm{W}^{.03} \mathrm{~W}$ will be deemed to have inade a similar gift to $\mathrm{H}$ and $\mathrm{C}$ except that the actuarial values used in determining the value of her retaimed life estate may be different froin H's. ${ }^{204}$ Interestingly, the gifts from $\mathrm{H}$ to $\mathrm{W}$ and $\mathrm{W}$ to $\mathrm{H}$ can be netted against each other so that only one will actually pay gift tax. ${ }^{205}$

203. See note 202 supra.

204. See note 63 supra and accompanying text.

205. See Rev. Rul. 69-505, 1969-2 Cum. Bull. 179. This netting actually provides a "tax break" for the transferor-spouses by reducing their total gift tax liability (and it will not increase their estate tax liability). Using the same facts as Example 1 and assuming $H$ was fifty and $W$ age forty-seven, the method of computation shown in this ruling is as follows:

Donor H:

One-half value of property

Less retained rights $(10,000.00 \mathrm{x}$ factor 0.51970 )

$\$ 10,000.00$

$\begin{array}{r}5,197.00 \\ \hline 4,803.00 \\ \hline \hline\end{array}$

Property transferred:

(a) to $\mathrm{W}-\$ 10,000.00 \times$ factor 0.11731

(b) to $\mathrm{C} \longrightarrow \$ 10,000.00 \mathrm{x}$ factor 0.36299

Donor W:

One-half value of property

Less retained rights $(\$ 10,000.00 \mathrm{x}$ factor 0.55436 )

Property transferred:

(a) to $\mathrm{H}-\$ 10,000.00 \times$ factor 0.08265

(b) to $\mathrm{C}-\$ 10,000.00 \times$ factor 0.36299

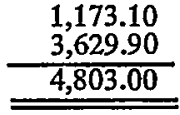

$10,000.00$

$\begin{array}{r}5,543.60 \\ \hline 4,456.40 \\ \hline\end{array}$

826.50

$3,629.90$

$4,456.40$

Recapitulation

\begin{tabular}{crr}
\hline & Donor $\mathrm{H}$ & Donor W \\
\hline Transfer to C & $\$ 3,629.90$ & $\$ 3,629.90$ \\
Net transfer to other joint tenant & $\frac{346.60}{}$ & $\frac{0.00}{\$ 3,629.90}$ \\
Total gifts made by parties & $\$ 3,976.50$ &
\end{tabular}

See id. at 180.

Explanatory notes to table: (1) The designation of " $\mathrm{H}$ " and " $\mathrm{W}$ " have been substituted for " $A$ " and " $B$," respectively, which appeared in the original text of this revenue ruling. (2) The .51970 factor for $H$ and the .55436 for $W$ are the entries for ages fifty and forty-seven, respectively, in Treas. Reg. $\$ 25.2512-5$ (f) (1954), coluinn 3, Table I (which is based on a factor of 31/2 percent). Treas. Reg. $\$ 25.2511-1$ (f) (1954) directs the use of this table. However, Treas. Reg. $\$ 25.2512-9$ (1970) indicates that 6 percent factor tables are to be used to value life estates after December 31, 1970. (3) The .11731 factor is the present worth of the right to receive the incoine from $\$ 1.00$ for the period of time that $W$ is expected to survive $H$. (4) The .36299 factor is the present value of $\$ 1.00$ that $\mathrm{C}$ will receive in the future after $\mathrm{H}$ and $\mathrm{W}$ are both expected to be dead.

The table indicates that $\mathrm{H}$ is deemed to have transferred to $\mathrm{W}$ an interest in property valued at $\$ 1,173.10$ and $W$ has transferred to $H$ an interest valued at $\$ 826.50$. Since the gift by $\mathrm{W}$ is less than the gift by $\mathrm{H}, \mathrm{H}$ is deemed to have made a gift to $\mathrm{W}$ of the difference in the amount of $\$ 346.60$. This gift qualifies for the $\$ 3,000$ per donee per annum exclusion. Treas. Reg. $\$ 25.2503-3$ (b) (1954). 
The gift to $C$ will not qualify for the $\$ 3,000$ annual exclusion because it is not a present interest. ${ }^{206}$

These principles are applicable where the following kinds of property held as joint tenants with right of survivorship (and not as tenants by the entirety) are transferred to an irrevocable trust: ${ }^{207}$

a. Personal property whenever acquired (except bank accounts and United States Savings Bonds).

b. All real property acquired before 1955 .

c. Real property acquired after 1954 for which gift tax returns were filed to report the gift of one-half interest from $\mathrm{H}$ to $\mathrm{W}$.

\section{Example 2}

$H$ provided all of the consideration to purchase Neuteracre on December 31, 1954; the title was taken by $\mathrm{H}$ and $\mathrm{W}$ as tenants by the entirety. Neuteracre is transferred to $\mathrm{H}$ and W's irrevocable trust at the time the trust is established; at that time Neuteracre has a value of $\$ 20,000$.

Because neither $\mathrm{H}$ nor $\mathrm{W}$ can unilaterally terminate the tenancy by entirety, the valuation of their interests inust take into account the life expectancies of $\mathrm{H}$ and $\mathrm{W}$. The first step is to calculate the value of the respective interests of $\mathrm{H}$ and $\mathrm{W}$ in the trust on December 31, 1973:

Value of Property transferred $\$ 20,000$

Less: Value of H's interest $(\$ 20,000 \times .41806)^{208} \ldots$

Value of W's interest $-\overline{\$ 11,639}$

$\mathrm{H}$ will then be deened to have nnade a taxable gift of $\$ 8,361$ (rather than one-half of the corpus as in the previous example) to $\mathrm{W}$ and $\mathrm{C}$ less the actuarially deterinined value of the life estate he retained in the $\$ 8,361$. W's taxable gift to $\mathrm{H}$ and $\mathrm{C}$ will be deemed to be $\$ 11,639$ less the actuarially determined value of her retained life estate in the $\$ 11,639$.

These principles are applicable where the following kinds of property held as tenants by the entirety are transferred to an irrevocable trust:

206. Treas. Reg. $\$ 25.2503-3$ (a) (1972).

207. The taxpayer may be in the unfortunate situation of paying a second gift tax. If H's contingent life estate were smaller than W's (so there would be a gift from $W$ to $\mathrm{H}$ ) and $\mathrm{H}$ originally put up all of the funds and paid the gift tax, then when the trust is set up, W will have to pay a gift tax for the privilege of giving H's property back to him. See id. $\$ 25.2515-4$ (b) (1954).

208. See notes 107-08 supra and accompanying text for a discussion of the computation of H's interest. 
a. Personal property whenever acquired.

b. Real property acquired before 1955 .

c. Real property acquired after 1954 for which gift tax returns were filed reporting the gift from $\mathrm{H}$ to $\mathrm{W}$ when the property was taken as tenants by the entirety. ${ }^{209}$

\section{Example 3}

$\mathrm{H}$ and $\mathrm{W}$ have $\$ 20,000$ in a bank account which they own as joint tenants with right of survivorship. $H$ made the entire deposit from his separate property, and neither spouse has made any withdrawals from the account. No gift tax return has been filed to cover the establishinent of the account. The funds in the account were transferred to $\mathrm{H}$ and W's irrevocable trust when it was established.

$\mathrm{H}$ would be deemed to have made a taxable gift of the full $\$ 20,000$ to $\mathrm{W}$ and $\mathrm{C}$ less the actuarially determined value of his retained life estate in one-half of the transferred property. ${ }^{210}$ W would incur no gift tax liability.

These principles are applicable where the following kinds of property are transferred to an irrevocable trust:

a. Bank accounts or United States Savings Bonds held as joimt tenants with right of survivorship. ${ }^{211}$

b. Real property acquired after 1964 , for which no gift tax return was filed, which is held either as joint tenants with right of survivorship, or tenants by the entirety. ${ }^{212}$

\section{(3) Conclusion}

Notwithstanding the obvious complexities involved in determining the federal gift tax consequences of establishing an irrevocable trust for jointly held property-and despite some uncertainty as to specific points-these gift tax considerations, in and of themselves, do not argue against the irrevocable trust for jointly held property. Any such argument nuust be expressed in terms of the alternatives. ${ }^{213}$ For example, a lifetime split of joint property followed by the establishment of a revocable trust for each spouse's portion of the split property, simply put, has distinct advantages not enjoyed by the irrevocable trust.

209. See notes $82-89,97$ supra and accompanying text.

210. See Treas. Reg. $\$ 25.2511-1(\mathrm{~h})(4)$ (1972). See notes $90-91$ supra and accompanying text.

211. See notes $90-91$ supra and accompanying text.

212. See notes 92-101 supra and accompanying text.

213. See text accompanying notes 195-200 supra. 


\section{B. The Revocable Trust}

\section{(1) Estate Tax Consequences}

The revocable trust is an appealing management concept. The creator of such a trust parts with no real dominion over the property, yet by a judicious selection of a trustee, he can obtain top quality financial management. ${ }^{214}$ For these reasons, it should have particular appeal for owners of joimtly held property who want to continue their joint beneficial interest in the property but want expertise in property management. Unfortunately, where joimtly held property is made the subject of a revocable trust, the estate tax consequences are somewhat unpredictable and definitely less appealing than those associated with an irrevocable trust. 215 An analysis of several cases will suggest this conclusion and atso focus on the underlying policy consideration.

In Hornor's Estate v. Commissioner ${ }^{210}$ the taxpayer lad established a revocable trust of joimtly leld property for the joint lives of himself and his wife. The trust was expressly revocable but only with the consent of both joint tenants. Neither could revoke the trust acting alone. By its terms the trust became irrevocable upon the death of the first to die of the joint tenants. In determining the taxpayer's federal estate tax liability, the court lield that the trust sliould be ignored and the property treated as if the taxpayer and his wife had made no transfer of the title to the trustee and had continued to hold legal title as tenants by the entirety. Having disregarded the trust, the court then easily applied section 2040 and mcluded the full value of the trust property in the gross estate of the first of the joint tenants to die subject to proof of contribution by the survivor. Here, the decedent was found to have provided all the consideration. ${ }^{217}$

The Hornor trust generated more bitigation when Mrs. Hornor

214. See generally American Bar Association Committee on Estate and Tax Planning, The Revocable Living Trust as an Estate Planning Tool, 7 ReAl ProperTy, ProBATE AND TRUST J. 223, 223-25 (1972).

215. It is assumed that the trust will continue to be revocable until both joint tenants are dead. For a discussion of the tax consequences where a trust becomes irrevocable upon the death of one of the spouses, see notes 236-73 infra and accompanying text.

216. 130 F.2d 649 (3d Cir. 1942), aff'g 44 B.T.A. 1136 (1941); accord, Estate of Frank N. Derby, 20 T.C. 164 (1953).

217. The lower court based its conclusion on the alternative grounds that (1) the trust was created in contemplation of death, 44 B.T.A. at 1139, and (2) the trust lacked substance because it was revocable and reserved the income interest, id. at 1140. In affirming, the Third Circuit specifically held that the fact that the trust was established in contemplation of death was irrelevant, $130 \mathrm{~F} .2 \mathrm{~d}$ at 651 . See also C. Lowndes \& R. KRAMER § 11.10, at 242 . 
died some years later. The trust had become irrevocable upon $\mathrm{Mr}$. Hornor's death and continued by its terms for Mrs. Hornor's life. The court held in Estate of Julia Crawford Hornor v. Commissioner ${ }^{218}$ that one-half the value of the trust should be included in Julia's estate on the ground that she had retained a life estate in the trust property. Here the case was not one of disregarding the trust but recognizing it and applying section 2036.

The court's position in Mrs. Hornor's case is arguably inconsistent with the position taken in her husband's case. In the first Hornor case, the court wanted to apply the federal estate tax rules on joint tenancy but found it could not do so because the statute did not con. template application in a trust context. ${ }^{219}$ The court, therefore, claimed the revocable trust to be a fiction and determined that the trust property retained its original character as joimtly held property. Then it became easy to take the next logical step and apply the mechanical rule of the federal estate tax and include all of the jointly held property in the estate of the first to die (except, of course, to the extent the survivor could prove contribution). ${ }^{220}$

Willianı Hornor was the sole contributor to the jointly held property; that fact resulted in the inclusion of all of the jomtly held property in his gross estate at his death. Nonetheless, the court in Julia Hornor found that Julia's life estate in the trust which became irrevocable at William's death should cause one-half of the trust corpus to be included in her gross estate. To do that, the court had to find that Julia transferred the trust property during her lifetime and retained a life estate in the transferred property. ${ }^{221}$ The court did so by finding that Julia had an interest in the jointly held property which she transferred to the trust when it was initially established. It was acknowledged that prior to the establishment of the trust Julia had only an expectancy in the jointly held property and under state law could not have unilaterally severed the joint tenancy by disposing of her interest during her lifetime. The court concluded, however, that state law required her consent to transfer the property to the trust and that she voluntarily jomed in the conveyance. As to the question of how much to include in Julia's estate as a transfer subject to a retamed life estate,

218. 305 F.2d 769 (3d Cir. 1962), aff'g 36 T.C. 337 (1961).

219. 130 F.2d at 651 . Even though a trust agreement might duplicate the legal effects of holding property as joint tenants with right of survivorship, section 2040 and its predecessor section would not reach the trust property. Hence, the court was forced to disregard the trust in order for the estate tax law to reach it.

220. Id.

221. INT. REv. CODE OF 1954, § 2036. 
the court explained its decision to include one-half in the following language: "Since neither petitioners nor respondent contend that a figure other than 50 percent of the property is includible in Juha's gross estate, assuming some percentage is includible, no discussion of this point is indicated."222

In the first Hornor case the court disregarded the state property law conception that the revocable trust had ended the joint tenancy and applied the federal estate tax rule of section 2040 as though the title was still held by Williain and Julia Hornor as tenants by the entirety. In the second Hornor case, Juha's actual ownership of an interest in the property, a state property law conception, was looked to as a means of qualifying Julia as a transferor for purposes of section 2036. Froin these cases, it is clear that the client who transfers jointly held property to a revocable trust with a reserved power of revocation in either joint tenant will have that property imcluded in the estate of the first to die except to the extent the survivor can prove contribution. It appears, too, that the trust property will be included in the estate of the first to die (except to the extent the survivor can prove contribution) even where both joimt owners must concur in order to revoke the trust. ${ }^{23}$ However, if the survivor can indeed establish her contribution, the question becomes one of whether the trust would be disregarded in order for the federal estate tax mechamical rule to apply in the taxpayer's favor. For example, if the non-contributing spouse was the first to die and the trust were disregarded, the contribution rules of section 2040 would exclude from her gross estate all of the trust property.

Whether the government will allow a revocable trust to be disregarded in such circumstances is difficult to assess. For example, it would be consistent with Julia Hornor for the government to claim one-half the trust property is includable in the non-contributing spouse's gross estate where she died first. The government could theorize that it was by her act and her act alone that half of the jointly

222. 305 F.2d at 772 .

223. See Hornor's Estate v. Commissioner, 130 F.2d 649 (3d Cir. 1942), discussed in notes 216-17 supra and accompanying text. It is arguable that the position taken in Hornor was erroneous because neither spouse could revoke without the consent of the other spouse. See Treas. Reg. $\S 20.2038-1$ (a)(2) (1962) which states that section 2038 does not apply "[i]f the decedent's power could be exercised only with the consent of all parties having an interest (vested or contingent) in the transferred property, and if the power adds nothing to the rights of the parties under local law ...." Id. In the case where jointly held property is transferred to a trust revocable only with the consent of both spouses and joint life interests are reserved, the trust instrument in most cases seems to add nothing to the spouses' rights in the jointly held property under state law. 
held property was transferred to the trust in which she had a life estate. $^{224}$ Thus she would be deemed to have made a transfer of property in which she retained a life estate. ${ }^{225}$ To reach this result, the government would have to recognize the validity of the revocable trust. Ordimarily the revocable trust is disregarded for tax purposes on the grounds that the transfer in trust is incomplete. ${ }^{228}$ Under state law, however, the revocable trust is deemed to create an interest in the trust estate in someone other than the grantor even though the trust remains revocable at the grantor's option. ${ }^{227}$ Admittedly, the state courts have been forced to this position in order to sustain revocable trusts as valid will substitutes against the argument that they are essentially testainentary and, as such, must comply with the formalities of execution required of wills if they are to be effective to pass property at the death of the grantor. ${ }^{228}$ Could it not be argued that the principles employed in the irrevocable trust cases $^{229}$ should also apply here to include, for example, only one-half the trust property in William Hornor's gross estate? Clearly, the quality of William Hornor's ownership interest changed once the jointly held property was placed in the trust, if for no other reason, because the trust was revocable only with the consent of his wife. That means, at the very least, that the trust had more substance than the garden variety re-

224. Cf. Miller v. Uuited States, 325 F. Supp. 1287 (E.D. Pa. 1971), discussed in note 147 supra. But cf. Estate of Koussevitsky, 5 T.C. 650,659 (1945), discussed in note 147 supra; 2 J. MERTENs $276 \&$ n.36 (1959). In Miller, the government also sought to include all of the trust property in the uon-contributing spouse's gross estate on the ground that the terms of the trust allowed the Millers to appoint new trustees (although it did not give them power to remove the existing trustees) if a vacancy occurred. The trustees would manage the trust property as if it were "their own individual property." 325 F. Supp. at 1292 . The government theorized that the Millers could have appointed themselves successor trustees and in that capacity enjoyed a taiuted "power to alter or amend (the trust) within the meaning of Section 2038." Id. at 1293. The court rejected this position. Id.

225. See INT. REv. CODE OF 1954, \$ 2036.

226. See id. \$ 2038; Treas. Reg. $\$ 25.2511-2$ (b) (1972).

227. Although state law will ignore certain inteuded gifts when the transferor fails to completely surrender dominion over the property, see A. SCOTT, THE LAW OF Trusts $\$ \S 32-33$ (3d ed. 1967), it is well-settled that a

trust is not incomplete merely because the settlor reserves power to revoke or to alter the trust. There is a sufficient surrender of control over the property if the settlor transfers title to it to the trustee, even though he reserves power to undo what he has done. Id. $\$ 37$, at 299 (footnotes omitted).

Thus, it would seem logical to conclude that both a joint tenancy and tenancy by the entirety will be severed when title to the property is trausferred to the trustee of a revocable trust since the joint tenants no longer have legal title to the property. Joint tenancy is a legal concept that looks to the state of the legal title rather than an equitable concept which considers who holds the beneficial interest in the property.

228. See, e.g., Farkas v. Williams, 5 Ill. 2d 417, 125 N.E.2d 600 (1955).

229. See note 191 supra and accompanying text. 
vocable trusts that consistently withstand attack in the state courts. ${ }^{230}$

A different decision in the William Hornor case would have been logically consistent with the decisions in Julia Hornor and Sullivan as it relates to the termination of joint tenancies in contemplation of death. ${ }^{231}$ In Sullivan the emphasis on state property law principles worked to the advantage of the taxpayer. In Julia Hornor it worked against the taxpayer. While there is a desirable consistency here in the application of state property law conceptions to determine federal tax consequences, this line of cases einphasizes form over substance. The premise of the federal estate tax is that those transfers of property (whether made during lifetime or at deathtime) in which dominion and control does not shift from the transferor until his death will be included in the transferor's gross estate for federal estate tax purposes. ${ }^{232}$ This same principle would have enabled the William and Julia Hornor trust to have escaped mclusion in Julia's gross estate. After all, so the reasoning goes, it never was Julia Hornor's property for federal estate tax purposes; for those purposes it was always her husband's. Thus, in this context, Julia Hornor was incorrectly decided and the William Hornor decision reflects the basic policy of the federal estate tax.

So too, in this context, was Sullivan incorrectly decided. Section 2035 was developed to prevent tax avoidance by taxpayers divesting themselves of all of their property as death approached. It provides generally that transfers within three years of death will be disregarded and that the federal estate tax will apply to the transferred property. In Sullivan that principle would have caused all the jointly held property transferred in contemplation of death to be taxed as if it had remaimed in joint tenancy. ${ }^{233}$

\section{(2) Gift Tax Consequences}

Establishment of a revocable trust which remains revocable until the death of both joint tenants has no federal gift tax consequences. ${ }^{234}$

230. See, e.g., Smyth v. Cleveland Trust Co., 172 Ohio St. 489, 179 N.E.2d 60 (1961). See also Annot., 39 A.L.R. 3d 14 (1971).

231. See notes $140-42$ supra and accompanying text.

232. See INT. Rev. CoDe of 1954, \$\$ 2033-42.

233. For a discussion of the policy considerations see notes 154-67 supra and accompanying text.

234. See Treas. Reg. $\S \S 25.2511-2$ (b), (c) (1954).

The federal income tax also generally disregards revocable trusts and imputes the income from such a trust to the settlor. See INT. Rev. CoDE of 1954, §§ 671-78; Rev. Rul. 66-283, 1966-2 Cum. BuLl. 297; Rev. Rul. 66-159, 1966-1 Cum. BuLl. 162; 6 J. Mertens $\S \S 37.01-.52$. 


\section{(3) Conclusion}

In these uncharted waters the courts should be looking to the substance of a transaction, and their decisions should reflect a basic policy to tax transactions which appear to be motivated by a desire to avoid estate tax. For this reason it becomes impossible to predict when state property law notions will control and when federal $\operatorname{tax}$ considerations will control. The tax strategist will shout "foul" in many of these cases but that is only because he exalts form over substance. It would seem that most of the transactions that run afoul of the tax laws are not the result of innocent decisions but the result of conscious design gone astray. Sometimes the courts go too far the other way and use a form of "hanging justice" to reflect the basic policy of the taxing statutes. That approach should be severely criticized. ${ }^{235}$ The lesson, then, is to test every proposed transaction against the policy of the taxing statute.

Nonetheless, because of the confusion in this area of the law and the possibility that the Service will take inconsistent positions, taxpayers should be aware that the transfer of jointly held property to a revocable trust may actually worsen estate tax consequences. Where the revocable trust is the only alternative acceptable to the taxpayer, he nay be better advised to continue to hold the property in joint tenancy.

\section{The Partially Irrevocable Trust ${ }^{236}$}

\section{(1) Generally}

There is another option available to the taxpayer who does not want to split his jointly held property during his lifetime but wants to do soine tax planning and also seeks professional management for

235. Such criticism might be appropriate with respect to the line of cases in which life insurance proceeds have been included in the insured's gross estate because ownership of the policies was transferred within three years of death and, as such, the transfers were presumptively deemed to be in contemplation of death. These cases seem to represent the use of "loopholes" in the tax law against the taxpayer rather than for him. See notes 162-66 supra and accompanying text. The Supreme Court, on the other hand, seems to have placed formalistic conceptions of dominion and control over transferred property ahead of substance. See United States v. Byrum, 408 U.S. 125 (1972).

236. This term seems to have been first used to describe a trust which is fully revocable but gradually over a period of time becoines partially irrevocable as the grantor releases percentile interests in the trust. See Sacher, Estate Planning and the Partially Irrevocable Trust: Another View of United States v. Byrum, 48 NOTRE DAME LAwYER 581 (1973). 
his property. It calls for the establishment of a revocable trust to which the jointly held property would be transferred. The trust agreement would contain special provisions that would make it become partially irrevocable on the death of the first to die of the joint tenants. The portion ${ }^{237}$ of the trust to become irrevocable would be that portion of the trust which is in excess of the amount of the trust property necessary to obtain the nnaximum marital deduction in the estate of the first to die. ${ }^{238}$ In determining the amount of trust property necessary to obtain the inaximum marital deduction, the governing imstrument must include a inechanism to take account of other property passing to the survivor which qualifies for the marital deduction in order to avoid over-qualifying the gift to the surviving spouse. ${ }^{230}$

This plan is based on the A and B trust arrangement discussed earlier. ${ }^{240}$ Essentially, this scheme contemplates the standard qualifying gift to the surviving spouse of an annount of the trust property equal to the maximum marital deduction reduced by any other property passing to the survivor and qualifying for the marital deduction..$^{241}$ The balance of the trust property which is included in the decedent's estate is to be set aside irrevocably in trust as the non-marital share. The share held in the non-inarital or irrevocable portion of the trust

237. Throughout this discussion reference will be made to the "irrevocable portion" of the trust. It is intended and assumed throughout that separate trust funds will be created to sheiter the revocable and irrevocable portions of the trust when one part becomes irrevocable on the death of the first spouse to die. While it is possible for one trust fund to contain both revocable and irrevocable portions, see Sacher, supra note 236, at 584, the reference in this Article to "irrevocable portion" which implies that there is only one trust fund, is used for convenience of reference only. It is suggested that such fractionalization will greatly compound the problems inherent in this scheme, particularly with respect to the marital deduction. See C. LowNDES \& R. KRAMER $\$ 42.10$.

What is intended with respect to the structure of the partially irrevocable trust, in its simplest form, is one trustee holding "separate trusts under one instrument without physical separation or segregation of the trust assets." Id. This is possible provided "the trust instrument authorizes such act and separate books and records aro maintained." Id.; see A. ScorT, supra note 227 , at \$ 77 .

238. That portion of the trust property which qualifies for the marital deduction will pass to the surviving spouse free of the federal estate tax. See INT. REv. CoDe of $1954, \S 2056$.

239. Property in excess of the maximum marital deduction which passes from a decedent to his spouse and qualifies for the marital deduction will be taxed in both the decedent's estate and his spouse's estate at her subsequent death unless she consumed it or disposed of it during her lifetime. See id. \$2056. There is an exception for annuities for the joint lives of husband and wife. Treas. Reg. $\$ 20.2056(b)-1$ (g) (3) (1974).

240. See notes 20-27 supra and accompanying text.

241. See note 27 supra and accompanying text. This portion of the trust will remain revocable for the life of the surviving spouse. The trust agreement will probably direct that upon the death of the surviving spouse the revocable portion be distributed to those persons specified as distributees of the irrevocable trust. 
will be taxed to the first to die and will escape taxation in the estate of the last to die. ${ }^{242}$ Thus, this scheme should cause the respective estates of the spouses to be equalized for federal death tax purposes.

In outline form, the partially irrevocable trust will look like this:

1. The trust will be completely revocable until the death of the first to die of the settlor spouses. ${ }^{243}$

2. Upon the death of the first of the settlor spouses to die, that portion of the trust which exceeds the maximum marital deduction allowed the estate of the first spouse to die will become irrevocable. ${ }^{244}$

242. See text accompanying note 24 supra.

The partially irrevocable trust scheme bears a likeness to the scheme considered in Hornor's Estate v. Commissioner, 130 F.2d 649 (3d Cir. 1942), and Estate of Julia Hornor v. Commissioner, 305 F.2d 769 (3d Cir. 1962). The partially irrevocable trust calls for all the trust property to be included in the estate of the first spouse to die except to the extent the survivor can prove contribution. In this respect, it is like Hornor. However, it differs from Hornor, in the respect that not all of the trust will become irrevocable at the death of the first to die. A portion of the trust will remain revocable in which event it will qualify for the marital deduction. See INT. REv. CODE OF 1954, $\$ 2056$. While qualification for the marital deduction is not critical to the success of the partially irrevocable trust as a tax saving device, see note 249 infra and accompanying text, the irrevocable portion of the trust can be made more acceptable to a client if he or she knows that the portion qualifying for the marital deduction will be available to them without restriction.

However, the partially irrevocable trust could be modified without loss of the marital deduction if it were thought that the surviving spouse needed not only professional management but also protection against the importunings of a second spouse or ler own inexperience in order to preserve the trust property for her lifetime and for lineal descendants. In such case, the so-called revocable portion of the partially irrevocable trust could also be made irrevocable at the death of the first spouse but the survivor would be given a life estate plus a testamentary general power of appointment over the remainder. This modification would allow the marital deduction to the estate of the first spouse to die with respect to that property in which the survivor has the life estate and general power of appointment. See INT. REv. CoDE of 1954, § 2056(b)(5). See text accompanying notes 22-23 supra.

243. Appropriate provisions with respect to revocation will lave to be placed in the trust agreement. The trust could be revocable at the option of either spouse either in its entirety or as to one-half or some other portiou. Or it could be made revocable only with the consent of both spouses as was the case with the Hornor trust. It should be noted, however, that requiring the consent of both spouses to revoke arguably could cause the establishment of the trust to have gift tax consequences even though it was revocable. For example, if the property included in the trust was held by the spouses as joint tenants with right of survivorship, the older spouse could be decmed to have made a gift to the younger spouse at the establishment of the trust because the older spouse's rights under the trust agreement would be worth less than his pre-trust rights (which included his right to transfer one-half the property without the consent of his spouse).

244. To obtain maximum advantage from this self-adjusting mechanisin in the trust, it would be appropriate for each spouse to execute a pour-over will making the trust beneficiary of all other probate property. See notes 20-23 supra and accompanying text. 
3. The surviving spouse will continue to have an interest in the irrevocable portion of the trust but her interest will not be such as to require the inclusion of this portion of the trust in her gross estate for federal estate tax purposes. There are, however, soine special problems here which will be discussed later in this Article. ${ }^{245}$

4. The revocable portion of the trust will continue to be revocable at the option of the survivor, and as such will qualify for the marital deduction. ${ }^{246}$ It is clear, of course, that this portion of the trust can be made irrevocable and still qualify for the marital deduction if the surviving spouse has a right to all of the income from this portion of the trust and, also, a general power of appointment over the remainder. ${ }^{247}$

The practical effect of the partially irrevocable trust is that the spouses must be willing for the survivor of them to have hittle or no control over the property held in the non-marital trust. This feature may be a significant deterrent to the use of this device. For example, if each spouse were willing, during lifetime, to allow a substantial portion of their jointly held property to be put irrevocably beyond his or her control, it would be appropriate in many cases for the spouses to work a lifetime sphit of this property as was suggested earher. ${ }^{248}$

More importantly, it must be recognized that if no part of the trust property is included in the estate of the first spouse to die, there will be no marital deduction since the sphit-off of the irrevocable portion of the trust is keyed to the marital deduction, and since there would be no inarital deduction, the entire trust will become irrevocable. That could happen when all the trust property was attributable to the resources of the survivor. ${ }^{240}$ For that reason, the planning should take a further step in anticipation of the fact that the non-contributing spouse may die first. The trust should provide that in the event the property passing to the survivor which qualifies for the marital deduction is less than the amount necessary to equalize the two estates

245. See notes $264-73$ infra and accompanying text.

246. If the Service includes all of the corpus of the revocable trust in the decedent's estate under section 2040 ("the gross estate shall include the value of all property to the extent of the iuterest therein held as joint tenants," INT. REv. CODE OF 1954, $\$$ 2040), the Service would seen to be bouud to allow a marital deduction under section 2056 ("such interest was, at the time of the decedeut's death, held by such person and the decedent ... in joint ownership," id. $\$ 2056(\mathrm{e})(5))$. The case involving the estate of Williain M. Hornor did not deal with tbis issue because the marital deduction was not available when Mr. Hornor died.

247. See note 242 supra.

248. See notes 64-70 supra and accompanying text.

249. If the survivor happened to be the domiuant party to the union, it is doubtful that he could tolerate this limitation on his uurestricted use of the property. 
for federal death tax purposes, the portion of the trust which becomes irrevocable shall be limited to one-half the spouses' combimed assets. Such a trust provision might provide:

In no event shall the portion of the trust becoming irrevocable exceed one-half the spouses' combined adjusted gross estates. The decedent's adjusted gross estate shall be the amount determined for federal estate tax purposes. The survivor's adjusted gross estate shall be determined as of the date of death of the first spouse but shall only include the survivor's separate property computed (1) as if she predeceased her spouse; (2) without reduction for those items specified as deductions in sections 2053 and 2054 of the Internal Revenue Code of 1954; (3) by excluding life insurance proceeds on policies of insurance on the survivor's life, life insurance cash values, interests in jointly held property, and the value of any property subject to any general power of appoimtment as defined by section 2041 of the Internal Revenue Code of 1954.

This limitation would require some provision allowing the trustee to rely upon the certification of the survivor as to the nature and extent of his property for federal estate tax purposes; otherwise there would be no objective measure of the survivor's estate. ${ }^{250}$

\section{(2) Illustration: Problems in Application}

There are several additional problems unique to the partially irrevocable trust which require the inclusion of special provisions in the trust agreement to prevent unwanted federal estate and gift taxation. The terms, purpose, and importance of each of these provisions can be best explained by describing through an example the tax consequences which result at the death of each spouse. For these reasons, consider the following illustration. $\mathrm{H}$ and $\mathrm{W}$, husband and wife, transfer $\$ 150,000$ of jointly held property to a trustee under a trust agreement which is expressly revocable for their jomt lives. At the death of the first spouse to die, a portion of the trust beconnes irrevocable; the balance remaining revocable for the life of the survivor. $H$ dies first. At his death, $\mathrm{H}$ was found to own $\$ 50,000$ of separate property which passed to $\mathrm{W}$ under his will. $\mathrm{H}$ provided all the consideration for the jointly held property.

250. This assumes, of course, the survivor's cooperation. To insure that later cooperation a provision could be placed in the trust conditioning the survivor's interest in the trust on her cooperation with the trustee on this point. Perhaps there should also be a provision in the trust to the effect that a certification by the survivor's legal guardian would be sufficient. 
1. All the jointly held property will be included in H's gross estate except to the extent $W$ can prove her contribution.

Inclusion of the jointly held property in H's gross estate will not be a disadvantage because of the estate splitting provisions available through the inarital deduction. In this case it will inean that H's estate will incur a federal estate tax liability of $\$ 4,800$. Of course, if W can prove that she provided all the consideration for the jointly held property, the jointly held property will be excluded froin H's gross estate and H's estate will incur no federal estate tax. However, even if W can prove that her resources were responsible for the acquisition of soine part or all of the jointly held property, the government inay insist upon the integrity of the revocable trust and deny $W$ the opportunity to prove her contribution. ${ }^{251}$ In that event, one-half of the jointly held property will be included in H's gross estate on the ground that this is the interest he transferred in trust subject to a retained life estate.

In either event, the surviving spouse should resist any temptation to prove her contribution to the jointly held property. ${ }^{252}$ That advice

251. See notes 224-25 supra and accompanying text.

252. Section 2040 is somewhat vague about who has the burden of proof with respect to contribution to jointly held property but the regulations clearly impose that burden on the decedent's executor. See Treas. Reg. $\$ 20.2040-1$ (a) (1954). The language of the regulations even implies that the matter of proof of contribution is committed to the executor and if he declines, the Service could not usurp his function. Id.

The entire value of jointly held property is included in a decedent's gross estate unless the executor submits facts sufficient to show that property was not acquired entirely with consideration furnished by the decedent ..... Id.

Attention should, however, be given to Richard V. Madden, 52 T.C. 845, aff'd per curiam, 440 F.2d 784 (7th Cir. 1971), in which it was held that for purposes of the basis rules of section 1014, the decedent's executor has the burden of proving that jointly held property was required to be included in the estate of the deceased joint tenant. In this case, the surviving spouse argued that the jointly held property had acquired as its basis for income tax purposes that value at which it was included in the estate of the deceased joint tenant. Noting that the estate tax rules for jointly held property have been on the books since 1916, the court said:

However, we cannot beheve that Congress contemplated that the term "required" should be construed so as to give survivors an option to decrease income tax by increasing estate tax, or to shift to the respondent, in income tax controversies, the burden of proving that less property was required to be included in gross estate than was actually included. There is no indication that Congress contemplated that it was conferring upon a surviving joint tenant the privilege of paying more estate tax than was necessary so as to reduce his income tax liability on the subsequent sale of the property. It seeins more likely that when the term "required" was used, it was assumed that the executor or other interested person would attempt to secure the maximum exclusion of the jointly owned property from the estate; only to the cxtent that the executor was unable to show that the property was not excludable was it required to be included in gross estate. Such an interpretation of "required" is consistent with the practice that existed in 1954 and has the effect of imposing the burden upon the person who has the information most readily available. Id. at 849 .

In considering Madden it may be appropriate to note that the government volun- 
is necessary if the partially irrevocable trust device is to fulfill its role as a device to equalize the spouses' respective estates. By its terms it anticipates that all the jointly held property will be included in the estate of the first to die, and therefore it is geared to the federal estate tax marital deduction. For this reason, it will be administratively simpler for all the jointly held property to be included in the estate of the first spouse to die.

Obviously, if $\mathrm{H}$ provided all the consideration for the jointly held property, the government will demand that the revocable trust be disregarded and everything be included in H's gross estate. ${ }^{253}$ This, of course, would be desirable.

2. The portion of the trust not qualifying for the inarital deduction in H's gross estate (but limited to one-half their combined assets) becomes irrevocable.

It will be held for $W$ for life; the remainder interest will be subject (probably) to a special power of appointinent in W. This event may or may not have federal gift tax consequences to W. Froin W's standpoint, the trust becoming irrevocable in part (and the gift becoming complete) is equivalent to the case previously discussed in which $\mathrm{H}$ and $\mathrm{W}$, while both were living, established an irrevocable trust for their jointly owned property. ${ }^{254}$ W's gift tax liability can be determined only after consideration of the kinds of property in the trust; when the trust property was originally acquired by $\mathrm{H}$ and $\mathrm{W}$; and whether $\mathrm{H}$ and $W$ held the property as tenants by the entirety or as joint tenants with right of survivorship prior to the establishment of the trust. ${ }^{255}$ The following examples are illustrative:

a. Where cash formerly held in a joint bank account is the only property in the trust, the fact that the trust becomes irrevocable would have no gift tax consequences for W..$^{258}$

tarily refunded the estate tax paid by the decedent's executor which was attributable to the inclusion of the joint property in her estate. The court seemed to find this significant. It said: "We are not concerned with a situation in which there has been a final determinatiou of the amount imcludable in gross estate; the estate tax return involved herein was not accepted by the respondent." Id.

Obviously, the standards for inclusion under sections 1014 and 2040 respectively are different. Perhaps, for that reason, it is inappropriate to even suggest that Madden may have any application where federal estate tax liability is at issue.

253. See notes 216-17 supra and accompanying text.

254. See notes 191-92 supra and accompanying text.

255. In analyzing transactions in terms of federal gift tax cost, the taxpayer must be constantly reminded of the gift tax exemption, exclusion, marital deduction and gift splitting provisions. See notes 125-28 supra and accompanying text.

256. See text accompanying notes 210-11 supra. 
b. Where $\mathrm{ABC}$ common stock which was formerly held as joint tenants with right of survivorship is the subject matter of the trust, $W$ will incur some gift tax liability when the trust becoines irrevocable unless the portion that remains revocable is at least equal to one-half the value of the stock. ${ }^{257}$

c. Where Neuteracre which was acquired, for example, on December 31,1954 by $\mathrm{H}$ and $\mathrm{W}$ as tenants by the entirety, is the subject matter of the trust when it becomes irrevocable, $W$ will incur no gift tax liability so long as the portion of the trust which remains revocable is at least equal to the actuarially determined value of her interest in Neuteracre at the time a portion of the trust becomes irrevocable. ${ }^{258}$

d. Where Greenacre which was acquired in 1960 by $\mathrm{H}$ and $\mathrm{W}$ as joint tenants with right of survivorship is the subject matter of the trust, there will be no gift tax consequences to $W$ at the time the portion of the trust becomes irrevocable. ${ }^{259}$

It has been assumed in each of the foregoing examples that the trust contained only one kind of property. Rarely will that be the case in practice. Where there are different kinds of property in the trust, can the trustee pick and choose which property shall be allocated to the revocable portion of the trust or will the allocation consist of a fractional interest in each itein of trust property? It must also be remeinbered that the size of the portion of the trust which becones irrevocable is dictated not by federal gift tax considerations but by a formula pegged to federal estate tax considerations. ${ }^{200}$ Perhaps these potentially conflicting interests can be reconciled by including a provision in the trust instrument directing the trustee to pick and choose the property to be allocated to the revocable and irrevocable portions of the trust after first considering the gift tax implications of his decisions to the surviving spouse. ${ }^{201}$

257. See text accompanying notes 202-07 supra.

258. See text accompanying notes 208-09 supra.

259. This illustration assumes that no gift tax was ever paid on this property. See text accompanying notes $210 \& 212$ supra.

260. See note 238 supra and accompanying text.

261. In order to insure the availability of the marital deduction in the estate of the first to die, a provision should be inserted in the trust requiring the trustee, in making the allocation to the revocable trust, to select items of property which are representative of the appreciation or depreciation experienced by the trust between date of death and date of allocation. See Rev. Proc. 64-19, 1964-1 Cum. Bull. 682.

It is theoretically possible that this allocation of property between the revocable and irrevocable portions of the trust will have capital gains consequences. In support of such a position, reference could be made to Rev. Rul. 69-486, 1969-2 CUM. BulL. 159 where the Service claimed a "sale or exchange" occurred within the meaning of section 1002 when a trust made a non-pro rata distribution of property. The ruling 
The more critical problem has to do with funding the revocable and irrevocable portions of the trust. In the absence of an express direction to the trustee with respect to such funding it is extremely doubtful that the government would allow the surviving spouse to claim that her fractional interest in the trust property (or property having a value equivalent to the value of her fractional interest) was allocated to the revocable portion. Probably the government would assume the contrary position. ${ }^{262}$ It would argue that it was the survivor's fractional interest in the trust property which became irrevocable. That would mean that all the trust property was included in the estate of the first of the spouses to die and that the same event-the death of the first spouse-caused the survivor to make a taxable gift of an interest in the same property. How can two people both transfer the same interest in the same property simultaneously? ${ }^{263}$ If it is possible, then the survivor

may be limited to its facts, see A. CASNER 1391 (Supp. 1973), but it may cast doubt on the validity of Rev. Rul. 56-437, 1956-2 CuM. BuLc. 507. That ruling stated that a division of property between co-owners does not constitute a taxable exchange. See note 80 supra for discussion of income tax consequences of terminating joint tenancies.

262. It would find ample precedent in Estate of Bomash v. Commissioner, 432 F.2d 308 (9th Cir. 1970), rev'g 50 T.C. 667 (1968). The decedent, Louis Bomash, established a testamentary trust and purported to fund the trust not only with his share of his marital community property but also that of his wife, Fannie. The trust provided that Fanmie would receive fifty percent of the income from the trust property. The court found that Fannie's consent to subject her half of the marital community property to Louis' trust qualified her as a "transferor" of property in which she retained a life estate for federal estate tax purposes. The court then held that Fannie's gross estate included fifty percent of the trust:

The retention of $50 \%$ income from the entire trust corpus (which includes Fannie Bomash's half contribution) is identical in substance to a retained $100 \%$ imcome life estate in her one-half of the commnnity property. The objective economic reality of this case is the fact that Mrs. Bomash did not alter her position by placing her community property share in trust. We are

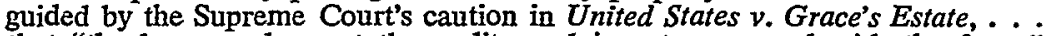
that "the law searches out the reality and is not concerned with the form." Most importantly, we heed the Grace Court's clear rule that "the taxability of a trust corpus * * * does not hinge on a settlor's motives, but depends on the nature and operative effect of the trust transfer."

Since the record demonstrates that (in the words of Grace) Mrs. Bomash's "effective position *** vis-a-vis the property did not change at all" when the trust was established, it was error for the Tax Court to conclude that the Bomash estate should not have been taxed on $50 \%$ of the entire trust's corpus. 432 F.2d at 311. (footnotes omitted).

As in the analogous Hornor cases, see notes 216-18 supra, all of the Bomash community property was included in Louis' gross estate at his death. Id. Thus, the court said, it is impossible to determine precisely in which portion of the trust Fannie had retained a life estate. The Tax Court had concluded that only twenty-five percent of the trust estate should be included in Fannie's gross estate. Id. at 310.

263. See Kaufman v. United States, 462 F.2d 439 (5th Cir. 1972). In this case the wife got more than half of the insurance proceeds from a policy owned by the community. The Service unsuccessfully argued that one-half of the proceeds that went to the daughters was a gift taken out of the wife's share of the community property. The court rejected the imposition of a gift tax because it "would plainly nean that, 
who fails to provide some mechanism for earmarking her portion of the jointly held property as that which continues in the revocable portion of the trust may find that she has made some unexpected taxable gifts.

Perhaps the appropriate manner in which to avoid unwanted tax liability in such a case would be to msert additional language in the trust further directing the trustee as follows:

In making the allocation of trust property between the revocable and irrevocable portions of the trust, the decedent's interest in the various items of trust property shall first be allocated to the irrevocable portion of the trust and the survivor's interest in those items shall first be allocated to the revocable portion insofar as practicable. The survivor's interest shall be determined by application of the rules developed for determining federal gift tax consequences of transfers of jointly held property.

This language should solve the problems of unwanted federal gift tax liability as a result of: (1) trustee decisions with respect to picking and choosing which items of property will be allocated to the irrevocable and the revocable portions of the trust, respectively; (2) government arguments that the portion of the trust which becanie irrevocable consisted of the fractional interest in each item of property attributed to the surviving spouse by state law.

3. At W's subsequent deatli, only that portion of the trust which continues to be revocable should be included in lier gross estate.

In order to insure this result and keep the irrevocable portion of the trust out of W's gross estate, it is imperative that all distributions from the irrevocable portion of the trust be completely at the trustee's discretion. ${ }^{204}$ Although $\mathrm{W}$ can be a permissible beneficiary of the irrevocable trust, she can have no right to demand any benefits of the trust.

This stipulation is largely the result of anticipating two distinct possibilities. The first is that W's resources might be found to have provided the consideration for the jointly held property. While the partially irrevocable trust agreement provides that a portion of the trust shall becoine irrevocable even if no part of the jointly held property is

upon the single event of the husband's death, the same 61,750 dollars would be taxed once through the estate tax on the husband's estate and once as a gift assessed to the wife on her husband's death." Id. at 441. The court explained: "When that spouse receives his or her share or more there must be some evidence of donative intent in order to assess a gift tax." Id. at 443 . But cf. Lewis v. United States, 485 F.2d 606 (Ct. Cl. 1973), discussed in note 285 infra.

264. See notes $274-75$ infra and accompanying text. 
included in the estate of the first to die, ${ }^{265}$ the government would certainly maintain that the irrevocable portion of the trust consisted of W's property. If $\mathrm{W}$ has a right to any benefits from the irrevocable portion of the trust, she will be deemed to have made a transfer in trust subject to a retained life estate. ${ }^{266}$

The second possibility which must be anticipated is a government attempt to imclude both the revocable and the irrevocable portions of the trust in W's gross estate at her death even thougli all the jointly held property was mcluded in H's gross estate at his death. ${ }^{267}$ The government would argue that the irrevocable portion of the trust contains a portion of the jointly held property attributed to $\mathrm{W}$ for federal estate tax purposes by prevailing law. To do so the government would have to disregard the plain instruction of the trust agreement to the effect that the interests of the first spouse to die in the various items of trust property are to be allocated to the irrevocable portion of the trust. ${ }^{268}$ Nonetheless, it would seem likely that the government would take this position. Arguably, the government would be maintaining imconsistent positions im permitting half of H's gross estate to escape taxation at H's death under the rubric of the marital deduction and then claiming at W's death that the portion whicl was taxed in H's estate at his death-the non-marital share now in the irrevocable trust-was really W's all the time. But really, the position is no more inconsistent than that taken in the two Hornor cases. In William $M$. Hornor, ${ }^{269}$ the court looked to the tax notion of contribution and, in

265. See notes 249-250 supra and accompanying text.

266. See INT. REv. CodE of 1954, § 2036.

267. See Estate of Julia Hornor v. Commissioner, 305 F.2d 769 (3d Cir. 1962), discussed in text accompanying note 218 supra; Miller v. United States, 325 F. Supp. 1287 (E.D. Pa. 1971), discussed in note 147 supra.

268. See text accompanying note 261 supra. This possibility suggests disastrous consequences. If the government takes this position, it would mean that:

a. All of the trust property would be included in the estate of the first spouse to die even where he or she provided none of the consideration for the jointly held property. See text accompanying notes 251-53 supra. (This result would be reached even if no trust were ever created.)

b. All the trust property would be included in the estate of the surviving spouse at her subsequent death. (This, too, would happen even if no trust were created and the property remained jointly held.)

c. The portion of the property included in the irrevocable trust would represent a gift for tax purposes by the surviving spouse. If this occurred it would mean that the same property was taxed in both estates for estate tax purposes and part of it was also subject to gift tax. Of course, the gift tax credit would be available to ameliorate the harshness of the result. See INT. REv. CODE of 1954, \& 2012. To eliminate this risk, distributions from the irrevocable trust must be at the discretiou of the trustee, and the surviving spouse may retain no rights in the trust. See text accompanying notes 274-75 infra.

269. Hornor's Estate v. Commissioner, 130 F.2d 649 (3d Cir. 1942), discussed in text accompanying note 216 supra. 
Julia Hornor ${ }^{270}$ it looked to state law conceptions. In the case of partially irrevocable trust, the government would be saying that all of the jointly held property was included in H's estate because he provided all the consideration and the irrevocable portion of the trust was included in W's estate because state law gave her an interest in the property which she allowed to be transferred to a trust in which she had a life estate. ${ }^{271}$

A different view-and an unlikely one-would be for the government to take the position that, in the absence of identifiable fractions, one-half of the portion which became irrevocable belonged to the survivor. $^{272}$ This position makes as much sense as any other. If it prevails and the survivor is found to have a life estate in the irrevocable portion, she will be deened a transferor of one-half of the irrevocable trust property at her death and that amount will be included in the gross estate. Since the inarital share of the deceased spouse's estatethe revocable portion of the trust-will be included in the survivor's estate at death, ${ }^{273}$ the addition of a portion of the irrevocable trust means double taxation in the same generation of the same property.

As noted above, the draftsman can anticipate these problems by the simple expedient of altering the survivor's rights in the irrevocable portion of the trust. Instead of a life income interest, the survivor will have to be content with a discretionary power in the trustee to distribute principal and income in such amounts as the trustee shall determine. Giving the trustee complete discretion over distributions should frustrate any suggestion that the surviving spouse has retained a life estate in the irrevocable portion of the trust. ${ }^{274}$ There inust obviously be an independent trustee and an absence of any evidence of any agreement or collusion between the donor and trustee with respect to the exercise of his discretion. ${ }^{275}$

270. Estate of Julia Hornor v. Commissioner, 305 F.2d 769 (3d Cir. 1962), discussed in text accompanying note 218 supra.

271. Cf. Miller v. United States, 325 F. Supp. 1287 (E.D. Pa. 1971); Estate of Koussevitsky, 5 T.C. 650 (1945).

272. Estate of Bomash, 50 T.C. 667 (1968), rev'd, 432 F.2d 308 (9th Cir. 1970), discussed im note 262 supra.

273. See INT. Rev. CODE of 1954, § 2038.

274. See National City Bank v. Commissioner, 241 F.2d 867 (7th Cir. 1957); Commissioner v. Irving Trust Co., 147 F.2d 946 (2d Cir. 1945); Herzog v. Commissioner, 116 F.2d 591 (2d Cir. 1941) (dictum); Zissman, Problem Areas in the Estate Tax, 41 TAXes 875, 884 (1963).

275. Cf. Estate of Skinner v. United States, 316 F.2d 517 (3d Cir. 1963); Commissioner v. Vander Weele, 254 F.2d 895 (6th Cir. 1958). But cf. Commissioner v. Irving Trust Co., 147 F.2d 946 (2d Cir. 1945); Herzog v. Commissioner, 116 F.2d 591 (2d Cir. 1941). 
The taxpayer and his spouse will be reluctant to commit the necessary kind of discretion to a disinterested trustee, but it is essential if the property subject to the irrevocable portion of the trust is to be excluded from the surviving spouse's gross estate at her death. ${ }^{276}$ Probably, the surviving spouse would feel better about the trust if the trustee's discretion were subject to some kind of standard such as maintenance, care and support. That, however, is not possible if the trust is to be excluded from the survivor's gross estate. ${ }^{277}$ While the survivor would not necessarily receive anything froin the trust unless the conditions were met, the trustee could be compelled to exercise his discretion in her behalf. However, it is the very existence of the standard that leads to another argument for the taxpayer. Since the trustee would have hittle discretion because of the standard, it is arguable that only that portion of the trust corpus which is attributable to the anount necessary for the survivor's maintenance, care and support should be included in her gross estate. The problem is one of valuation. How shall the court determine the value of the right to maintenance, care and support? In one case which is factually analogous, the decedent retained the right to receive $\$ 100$ per month from the income of the trust and the court concluded that only that portion of the trust corpus necessary to produce $\$ 100$ per month should be included in the decedent's gross estate. ${ }^{278}$

One can only speculate whether a court would attempt to value the portion of the trust necessary to produce an. annount determined, perhaps by hindsight, to be equal to the value of the right to maintenance, care and support. It is probable that such a judicial determination would be refused on the ground that the decedent could look to the entire trust corpus for satisfaction of his right to income. ${ }^{270}$ It comes to mind, however, to ask how that is different from the case

276. Perhaps it is appropriate to note that with the discretionary pay feature a part of the irrevocable trust, it is no different for tax purposes from the case where the property remained jointly held, and at the death of the first spouse the survivor established an irrevocable trust with a discretionary pay feature. See text accompanying note 274 supra. The partially irrevocable trust has appeal, however, in cases where professional management of jomtly held property is important during the lifetime of both spouses. While a transfer of all the jointly held property to an irrevocable trust while both spouses are alive will have approximately the same tax consequences as the partially irrevocable trust, compare notes 190-212 supra and accompanying text, with notes 237-73 supra and accompanying text (gift taxes will be greater with the irrevocable trust), the partially irrevocable trust affords greater flexibility in that a portion of the trust will remain revocable for the life of the surviving spouse.

277. Commissioner v. Irving Trust Co., 147 F.2d 946, 949 (2d Cir. 1945) (dictum).

278. National City Bank v. Commissioner, 241 F.2d 867 (7th Cir. 1957).

279. See Toeller's Estate v. Commissioner, 165 F.2d 665 (7th Cir. 1948). 
where the decedent could look to all the trust income to satisfy his retained right to $\$ 100$ per month from that income. ${ }^{280}$

While giving the survivor a discretionary life income interest rather than a inandatory pay interest has obvious federal estate tax savings appeal, it may have negative significance for gift tax purposes. So long as the survivor had a mandatory pay life estate in the irrevocable portion of the trust, the only gift she would be deemed to have made was the remainder interest in that portion, if any, of the irrevocable trust which is attributed to her for federal gift tax purposes. ${ }^{281}$ If all distributions froin the trust are at the discretion of an independent trustee, it would seem the surviving spouse will be deemed to have made a taxable gift of all that portion of the irrevocable trust which is attributed to her without any reduction for the value of a retained life estate. ${ }^{282}$ This, of course, assumes that the irrevocable portion of the trust will be treated as holding the surviving spouse's portion of the jointly held property. ${ }^{283}$ Hopefully, the special provision included in the irrevocable trust for this purpose will prevent this result. ${ }^{284}$

\section{(3) Lewis v. United States}

In Lewis $v$. United States ${ }^{285}$ the decedent's will purported to dispose of the property which he and his spouse, Nellie, held as tenants by the entirety. For reasons not important to this analysis, the tenancy by the entirety was not to be terminated during the spouses' joint lifetimes. Therefore, in order to make her husband's will operational with respect to the tenancy by the entirety property, Nellie executed an "irrevocable" trust agreement directing that the tenancy by the entirety property be distributed under her husband's will. Her husband died some months later and Nellie survived. Pursuant to the terms of Nellie's trust, the tenancy by the entirety property was distributed under her husband's will. The court held that all the tenancy by the entirety property was includable in the husband's gross estate and that Nellie made a taxable gift of all of the tenancy by the en-

280. National City Bank v. Commissioner, 241 F.2d 867 (7th Cir. 1957).

281. Whether she had an interest would be determined by considerations of actuarial factors, state law, and rules of contribution. See notes 254-63 supra and accompanying text.

282. See Herzog v. Commissioner, 116 F.2d 591 (2d Cir. 1941); Rheinstrom v. Commissioner, 105 F.2d 642 (8th Cir. 1939); Estate of Ben F. Hazelton, Jr., 9 P-H Tax Ct. Mem. If 40,425 (1940). But see Commissioner v. Vander Weele, 254 F.2d 895 (6th Cir. 1958); Rev. Rul. 62-13, 1962-1 CuM. Bull. 181.

283. See notes 262-63 supra and accompanying text.

284. See notes 262-63 supra and accoinpanying text.

285. 485 F.2d 606 (Ct. Cl. 1973). 
tirety property at his death when she allowed this property to be disposed of by his will.

It is unfortunate that the Lewis court did not better explain its decision. One could conclude from a casual reading of the opinion that it would be precedent for holding that the partially irrevocable trust would (1) not only cause all the trust property to be subject to federal estate taxation at the death of the first spouse to die, but, (2) also cause that portion which becomes irrevocable at the death of the first to die to constitute a taxable gift from the survivor. It is the latter possibility which would be disadvantageous simce it would mean, practically speaking, that all of the trust property would have been included in the estate ${ }^{286}$ of the first spouse to die and would also be treated as a taxable gift by the survivor.

Turning to Lewis, a careful reading will suggest that the socalled "irrevocable" trust was no trust at all until such time as Nelllie's spouse died. ${ }^{287}$ It was only at that time that the trust acquired a res and, accordingly, only then that it came into being. Had the jointly held property in Lewis been held in joint tenancy with right of survivorship (rather than as tenants by the entirety), Nellie could have severed the joint tenancy without her spouse's consent and transferred one-half of the jointly held property to the trust. Since the property was held as a tenancy by the entirety she could make no such transfer to the trust during her lifetime unless her husband joined in the conveyance. Hence at Mr. Lewis's death, Nellie's interest in the tenancy by the entirety expanded by operation of law to include the entire property, and, at that point in time, she had the unrestricted right to dispose of all the jointly held property as she saw fit. Her promise to transfer the property to the trust was unsupported by consideration and, while a moral obligation, it was otherwise unenforceable. ${ }^{288}$

286. Of course, the marital deduction would be available as to that property included in the revocable portiou of the trust. See INT. REv. CODE OF 1954, § 2056.

287. Nellie, a resident of Pennsylvania, assigned to the trustee the right that she would have had in the jointly held property if she were the surviving tenant. Under Pennsylvania property law a tenant by the entirety has "nothing more than a mere expectancy" while both tenants are still alive. Estate of Julia Hornor v. Commissioner, 305 F.2d 769, 771 (3d Cir. 1962). Ordinarily, an "expectancy" cannot be the subject matter of a trust. See A. ScotT, supra note 227, § 86.1. A valid trust cannot exist without a subject matter (the res).

288. See Restatement (Second) of Trusts $\$ 30$ (1959); Ritchie, Alford \& EFFLAND, DECEDENT's Estates \& TRUSTS 383-84 (4th ed. 1971).

It could be argned that Nellie had a contingent right of survivorship in the tenancy by the entirety property and that it was assigned to the trust when it was estabhished (thereby giving the trust a res from its inception). That, however, is uot how the court saw the issue or else it could not have reached the result that it did. The 
Thus, her transfer of the property to the trust after her husband's death was purely gratuitous and legally unnecessary. ${ }^{280}$ It was therefore a transfer subject to federal gift tax to the extent it was complete. $^{200}$

The partially irrevocable trust is unlike Nellie Lewis's "irrevocable" trust in the sense that the jointly held property is actually transferred to the partially irrevocable trust by the action of both spouses while they are both living. From that point forward, conditions for the enjoyment of the property are determined by the terms of the trust agreement and not by state law as was the case in Lewis where the transfer in trust did not occur until Nellie's spouse died. It would be incorrect to suggest that the property in a partially irrevocable trust remains jointly held, and therefore at the death of the first spouse to die the survivor could choose whether to transfer the jointly held property to the trust or make some other disposition as Nellie Lewis could do. Nellie Lewis was in this position because her so-called "irrevocable" trust had not affected her survivorship rights in the tenancy by the entirety property. In the case of the partially irrevocable trust, the joint tenancy relationship was terminated for state law purposes when the property was conveyed to the trust.

While the partially irrevocable trust will be disregarded for federal estate tax purposes so long as it remains revocable and the trust property treated as if it had remained jointly held, the issue under consideration is what interest could the surviving spouse transfer for gift tax purposes when the trust becomes irrevocable in part. That can only be determined by the kind of property involved, the time it was acquired, and whether gift tax returns were filed.201 For example, if shares of $\mathrm{ABC}$ corporation were held in joint tenancy with right of

court held that a gift was made when Nellie's husband died and Nellie allowed the tenancy by the entirety property to pass to the trust. Had the court believed that Nellie transferred a contingent right of survivorship to the trust at its inception, the gift would be deemed to have been made at that time and not at the death of Nellie's husband. Nellie could not have been deemed to have made gifts on both occasions of the same property interest.

In this case it should be noted that the court found the evidence indicated that Nellie's irrevocable trust was considered revocable by Nellie and the trustee. 485 F.2d at $613 \mathrm{n} .8$. In the event that the trust was in fact revocable, no gift tax would be due because the gift would be incomplete. Treas. Reg. $\S 25.2511-2$ (1954).

289. The court said that "upon lier husband's death, plaintiff transferred (via the provisions of the trust agreement) lier ownership of the margin account . . ." 485 F.2d at 614. However, this statement should not be read to mean that Nellie had to transfer the property; rather the court is just reciting what Neilie let happen.

290. See Treas. Reg. \$ 25.2511-2 (1954).

291. See text accompanying notes 80-101 supra. 
survivorship prior to being placed in the trust, the only taxable gift either spouse could have made was of a one-half interest. ${ }^{202}$ This one-half interest would have been all Nellie Lewis could have given away had she been able to make the transfer effective prior to the time that the right of survivorship mechanisin operated to give her the entire interest in the jointly held property. In the case of the partially irrevocable trust, the survivorship mechanisin has been destroyed and there is no way that the surviving spouse could find herself in Nellie's position once the transfer to the trust has been accomplished.

Admittedly, a portion of the partially irrevocable trust becomes irrevocable at the death of the first spouse to die, but, theoretically, that portion of the trust contained the decedent's portion of the jointly held property. ${ }^{203}$ The survivor's portion of the jointly held property remains in the revocable portion of the trust. While there may be reasons for imposing a gift tax upon the survivor, ${ }^{294}$ the fact that a portion of the trust becomes irrevocable is not one of thein.

\section{(4) Revenue Ruling 71-51}

Revenue Ruling $71-51^{295}$ presented a situation somewhat similar to that contemplated by the partially irrevocable trust. In the situation presented in the revenue ruling, husband and wife owned property as joint tenants with right of survivorship. The husband died in 1954. Soine years prior to his death, he and his wife had executed a joint, mutual, and contractual will which provided that

all property, real as well as personal, of whatever kind and wherever situated at the time of the death of either, was to be held by the survivor during his or her life with the right to the income therefrom for life. Upon the death of the survivor, the remainder interest in the propenty was to be distributed to their children. 290

The Service ruled that the jointly held property qualified for the inarital deduction in the husband's estate in that all of it was included in

292. See notes 84-85 supra and accompanying text. Speculation about the consequences of disregarding the trust for gift tax purposes leads nowhere. For example, if the trust is disregarded for gift tax purposes, the spouses will find themselves holding the property jointly and making transfers of jointly held property. The gift tax consequences of such transfers have already been examined. See text accompanying notes 80-101, 201-12 supra.

293. See notes 262-63 supra and accompanying text.

294. See text accompanying notes 262-63 supra.

295. 1971-1 Cum. ButL. 274. It should be noted that this revenue ruling is the estate tax counterpart of the Lewis case.

296. Id. at 274-75. 
the wife's gross estate on the ground that she had transferred the property subject to a retained life estate.

It could be suggested that this revenue ruling will cause the government to include not only the revocable portion of the partially irrevocable trust but also the irrevocable portion of the trust in the survivor's gross estate on the ground that she retained a life estate in the irrevocable portion. While this position is arguable, it suffers two distinct weaknesses. First, the ruling is premised on the notion that the contractual limitation on the disposition of the jointly held property could not prevent the survivor's interest in that property froin ripening or expanding to include the entire interest at the death of the first spouse to die. It is almost as if the Service were analogizing to Lewis and suggesting that the surviving spouse in the situation presented by the ruling could choose to ignore the terms of her contractual undertaking and dispose of the jointly held property to a third person. That is probably true, but the beneficiaries under the contractual will would have an action against her for damages for breach of contract. ${ }^{207}$

The second weakness is to an extent premised, as was the first, on the notion that the contractual will could not encumber the jointly held property in any way to prevent the survivor from disposing of it as she pleased. On that assumption, the ruling is correct in holding that all the jointly held property subject to the contractual will should be in her gross estate as a transfer subject to a retained life estate since she had the right to all the income for life. ${ }^{208}$ However, the question becoines one of asking whether there is any inconsistency between the position of the ruling and those cases where jointly held property has been placed in an irrevocable trust and each joint tenant is deeined to have a one-half interest for federal estate tax purposes. ${ }^{200}$ The answer probably is that there is no real conflict given the preinise of the ruling that the joint tenancy relationship was never terminated until the death of one of the spouses. In all the other situations examined in this Article in which only one-half the property was included in the estate of the first to die, the joint tenancy relationship had been clearly terminated during the joint lifetime of the spouses.

For purposes of the partially irrevocable trust, the issue becomes one of determining whether the joint tenancy relationship is terminated by the transfer of the jointly held property to the trust so long as the

297. See RITCHIE, AIFORD \& EFFLAND, supra note 288, at 731-33.

298. See INT. REv. CODE OF $1954, \S 2036$.

299. See, e.g., Estate of Julia Hornor v. Commissioner, 305 F.2d 769 (3d Cir. 1962 ), discussed in text accompanying note 218 supra; Sullivan's Estate v. Commissioner, 175 F.2d 657 (10th Cir. 1949), discussed in text accompanying notes 140-42 supra. 
trust is revocable. The Service would probably agree that it was. In the ruling, emphasis was placed on the state law notion of survivorship inherent in the joint tenancy relationship (as was also done in Lewis). Since the revocable trust terminates the joimt tenancy relationship for state law purposes ${ }^{300}$ - clearly, the beneficiaries of the partially irrevocable trust are marching to the tune of the trust agreement and not state law notions about joint tenancies-the principle of the ruling should have no application to the partially irrevocable trust.

\section{(5) Summary}

Many chents inay find the discretionary pay feature of the irrevocable portion of the trust too high a price to pay for estate tax certainty. Given the context of clients who are reluctant to terminate joint ownership arrangements, perhaps it is wishful thinking to even propose the partially irrevocable trust. Nonetheless, it would seem that a trust of this sort would have appeal in cases where one of the spouses is clearly the dominant party to the union. In that kind of case, the dominant party will probably welcome some device to limit the dominated party's interest in the jointly held property after the death of the dominant party.

In the ordinary case, perhaps the partially irrevocable trust can be "sold" on the ground that one-half the property will clearly be available to the survivor in the revocable trust. Thus, the survivor only compromises control as to the irrevocable portion of the trust.

From this discussion, it should be apparent that it is clearly preferable to equalize the respective estates of the spouses during lifetime for maximum tax advantage. ${ }^{301}$ Nonetheless, for those who are reluctant to accomplish such equalization, yet want tax savings and/or professional inanagement, the partially irrevocable trust has appeal. In fact, the partially irrevocable trust differs froin the estate equalization scheme discussed earher in only one particular: the discretionary pay feature of the irrevocable trust. In cases where the discretionary pay feature is a stumbling block to the use of the partially irrevocable trust and the clients are unwilling to equalize their estates, perhaps it would be appropriate to give the survivor a right to income from the irrevocable trust and accept the estate tax risks that it entails. ${ }^{302}$

300. See note 227 supra. The Gift Tax Regulations state that a joint tenancy relationship is terminated anytime the joint tenants "alter the nature of their respective interests in the property." Treas. Reg. $\$ 25.2515-1$ (d)(2) (1954).

301. See notes 64-79 supra and accompanying text.

302. See note 268 supra. 
The one true disadvantage of using the partially irrevocable trust is that it remains untested in the courts. For that reason it lacks predictability, the most important ingredient to successful preventive law practice. However, in those cases where taxpayers want both tax savings and control over property, they inust be prepared to sacrifice predictability. Lawyering is a process of developing alternatives and making predictions as to their success. It is for the client to choose among the alternatives after giving what he beheves to be appropriate weight to predictability of result.

In summary, then, the partially irrevocable trust is clearly analogous to the traditional $\mathrm{A}$ and $\mathrm{B}$ trust arrangement, but it differs in several important particulars.

a. Because the trust is funded with jomtly held property, it should be possible in many cases to achieve the inuch desired estate equalization between the spouses without regard to the order of their death. In order to make that possible, the trust agreement must contain a provision requiring a portion of the trust containing the jointly held property to become irrevocable when the first spouse dies, whether or not any portion of the jointly held property is includable in that spouse's gross estate for federal estate tax purposes. ${ }^{303}$

b. To avoid adverse federal gift tax consequences the trust must contain special provisions regarding allocation of the property in the trust between the revocable and irrevocable portions. ${ }^{304}$

c. All distributions from the irrevocable portion of the trust inust be at the coinplete discretion of the trustee. ${ }^{305}$ Although the surviving spouse may be a permissible beneficiary under the irrevocable portion of the trust, she inay have no right to demand any benefits from that portion of the trust.

Turning back to the illustration involving $\mathrm{H}$ and $\mathrm{W}$, it appears that use of the partially irrevocable trust will mean that H's and W's estates will each incur a federal estate tax liability of $\$ 4,800$ without regard to the order of their deaths. However, if they had not established a partially irrevocable trust but continued to hold their property as joint tenants, the federal estate tax liability, if $\mathrm{H}$ had died first, would have been $\$ 4,800$ at H's death and $\$ 32,700$ at W's death. (If W had died first, all the joimtly held property would be included in her estate except to the extent $\mathrm{H}$ could prove contribution. If $\mathrm{H}$ could not prove

303. See text accompanying note 242 supra.

304. See text accompanying notes 262-63 supra.

305. See text accompanying notes 274-75 supra. 
contribution, the federal estate tax at W's death would be $\$ 1,050$ and at H's subsequent death, $\$ 32,700$. (Or if $\mathrm{H}$ could prove contribution, nothing would be included in W's gross estate at her death, and at H's death the federal estate tax liability would be $\$ 32,700$.) Had H and $\mathrm{W}$ used a conventional $\mathrm{A}$ and $\mathrm{B}$ trust arrangement, and $\mathrm{H}$ died first, H's federal estate tax liability would have been $\$ 4,800$ and W's would have been $\$ 17,900$. (If $W$ died first, nothing would have been included in her gross estate and at H's subsequent death his estate would incur a federal estate tax of $\$ 32,700$.) And if the estates were equalized between the spouses during lifetime (and the first to die established an irrevocable trust of his property for the survivor for life), the federal estate tax at the death of each spouse would be $\$ 4,800$ without regard to the order of their deaths.

\begin{tabular}{|c|c|c|c|}
\hline \multicolumn{4}{|c|}{$H$ Dies First } \\
\hline & H Estate Tax & W Estate Tax & Total \\
\hline No trust; property jointly held & $\$ 4,800$ & $\$ 32,700$ & $\$ 37,500$ \\
\hline Conventional A and B Trust & 4,800 & 17,900 & 22,700 \\
\hline Partially Irrevocable Trust & 4,800 & 4,800 & 9,600 \\
\hline Estate Equalization & 4,800 & 4,800 & 9,600 \\
\hline \multicolumn{4}{|c|}{$W$ Dies First } \\
\hline No trust; property jointly held & $\$ 32,700$ & $\$ 1,050$ & $\$ 33,750$ \\
\hline Conventional A and B Trust & 32,700 & 1,050 & 33,750 \\
\hline Partially Irrevocable Trust & 4,800 & 1,050 & 5,850 \\
\hline Estate Equalization & 4,800 & 4,800 & 9,600 \\
\hline
\end{tabular}

\section{Postmortem Planning}

No doubt there will be cases when, through oversight or lack of understanding, taxpayers whose estates consist largely of jointly held property will employ the conventional $\mathrm{A}$ and $\mathrm{B}$ trust arrangement. In such cases, the survivor will have an opportunity to make her estate responsive to the plan since the plan is not responsive to the estate. To do so, the survivor inust be prepared to disclaim that portion of the jointly held property passing to her which is in excess of the maximum marital deduction available to the decedent's estate. She will be expected to argue that she never had dominion and control over the property and that this is the first opportunity she has had to demonstrate her refusal to accept the gift. ${ }^{306}$ Naturally, this reasoning assumes that the surviving spouse has never exercised any dominion

306. The taxpayer in Lewis attempted a similar argument and got nowhere. The court said, "Although completely passive, she still had the capability of control and that power did not atrophy because of the lack of exercise." 485 F.2d at 611 (citations omitted). 
over the property for her own benefit. To the extent she has exercised such dominion she would argue that it was exercised for the benefit of the family unit and that the joint tenancy relationship was estabestablished for convenience only.

While disclaimers are expressly sanctioned by the Treasury Regulations, ${ }^{307}$ the courts have almost uniformly resisted any effort by a survivor to disclaim an interest in jointly held property. ${ }^{308}$ This resistance is difficult to understand given the increasing willingness on the part of state courts to take evidence-at least in the case of joint bank accounts-on the issue of whether the survivor took the jointly held property at the contributor's death. ${ }^{309}$ One state, South Dakota, has recently gone so far as to specifically authorize disclaimers of jointly held property. ${ }^{310}$ Unfortunately, there are no reported cases under this statute which consider the federal gift tax consequences of such disclaimers. It would be assumed, however, that the judicial resistance would weaken given the Service's position (as expressed in the Regulations ${ }^{311}$ ) that local law is controlling on the question of disclaimers.

307. See Treas. Reg. $\$ 25.2511-1$ (c) (1954).

308. See Krakoff v. United States, 439 F.2d 1023 (6th Cir. 1971); Bishop v. United States, 338 F. Supp. 1336 (N.D. Miss. 1970), aff'd mem., 468 F.2d 950 (5th Cir. 1972); Lewis v. United States, 485 F.2d 606 (Ct. Cl. 1973). Contra, Estate of Chrysler v. Commissioner, 361 F.2d 508 (2d Cir. 1966). By way of explanation, it has been stated:

[W]ill the survivor be able to disclaim what passes under the right of survivorship? It would seem that a disclaimer in this situation comes too late because the original acquiescence in the establishment of the joint ownership is an acceptance of a property interest which cannot be eliminated except by a transfer. Of course, if the survivor has done nothing as yet to indicate acquiescence in the establishment of the joint ownership, he should be able to refuse to accept what was given him originally, including any benefit from the right of survivorship. A. CASNER 1038 (Supp. 1973).

The negative attitude the courts have taken toward disclaimers is hard to reconcile with decisions hike Estate of Albert Rand, 28 T.C. 1002 (1957), in which the surviving spouse was able to have excluded from her deceased husband's gross estate that portion of his property which she was deemed to have given him for convenience. The property was not jointly held. Title was in his name alone. The Internal Revenue Service acquiesced to this decision in 1958-2 Cum. BulL. 7.

309. See note 51 supra and accompanying text. uto:

310. S.D. CoMp. Laws $\S 43-4-29$ (Supp. 1973). Consider the language of the stat-

Any person who may be entitled to receive any property or beneficial interest, vested or otherwise, under any will of or by inheritance from a decedent, or as a surviving joint tenant of a decedent, or under the terms of an inter vivos trust shall have the right to disclaim irrevocably the whole or any part of such property or beneficial interest. Id. (Emphasis supplied.).

See also A. CASNER 1040 (Supp. 1973).

311. "Where the law governing the administration of the decedent's estate gives a beueficiary .... a right to completely and unqualifiedly refuse to accept ownership ..., a refusal to accept ownership does not constitute the making of a gift ...." Treas. Reg. $\$ 25.2511-1$ (c) (1954). This regulation does not expressly include the renunciation of a joint tenant's interest. 


\section{CONCLUSION}

It goes without saying that estate planning is made more difficult by the presence of jointly held property in the estate. The advent of the marital deduction in 1948 imposed a special charge on lawyers engaged in estate planning. When it is determined that a taxpayer's estate will be subject to federal estate tax, the lawyer is obligated to advise the taxpayer about the benefits of the marital deduction, principally the opportunity to have one-half of his property taxed to hin at his death and the other one-half taxed to his wife at her death. While the marital deduction is available as to jointly held property, the presence in an estate of jointly held property in excess of one-half of the decedent's adjusted gross estate will frustrate the common A and $B$ trust arrangement and, in many cases, cause the federal estate tax to apply a second time to that property which was taxed to the husband at his death. If this so-called second tax is to be avoided on jointly held property and the estates equalized for federal estate tax purposes, the surviving joint tenant inust be willing to inake gifts during the balance of her life of that portion of the jointly held property which was taxed to the first joint tenant at his death. While the survivor may retain no interest in the transferred property if the gift program is to be effective in avoiding the second tax, it is possible for the survivor to transfer the excess jointly held property to a trust after the death of the first joint tenant and give the trustee complete and unrestricted discretion to distribute income and principal from the trust for the benefit of the survivor and yet keep this property out of the survivor's estate for federal estate tax purposes. However, inost taxpayers are not willing to place their resources beyond their control during their lifetimes.

The only realistic solution to planning for jointly held property is to counsel the taxpayer to split the jointly held property between himself and his spouse during lifetime in such a way as to equalize their respective estates. Each spouse should then make a will directing that all of his property be held in trust for the survivor for life, remainder as the survivor shall appoint among a limited class of persons, probably the taxpayer's children. The trustee can have discretion to distribute principal from the trust where necessary for the maintenance, care, and suppont of the survivor without adverse estate tax consequences. Moreover, the trust for the survivor can be excluded from the survivor's gross estate for federal estate tax purposes even when the survivor is trustee of such a trust. 


\section{EPILOGUE}

While estate planning for jointly held property is important, the most significant contribution that the lawyer can make is to discourage the use of jointly held property except with respect to residential real estate $^{312}$ and sinall amounts of cash in checking accounts. Admittedly, in those estates where tax planning will never be important-if it is ever possible to make that prediction with complete accuracy-jointly held property should be encouraged. ${ }^{313}$ For that reason it is hard to argue that the bias of most laymen (and, unfortunately, some attorneys) in favor of joint tenancy should be changed but, perhaps, at the very least, banks and other savings depositories should refrain froin indiscriminately recommending this form of property ownership. ${ }^{314}$

312. Residential real estate is not an especially suitable item for trust management.

313. See T. SHAFFER, supra note 1, at 59-63 (1972).

314. It is clear that trust departments of most banking institutions discourage joiut tenancies with right of survivorship. Unfortunately, in too many cases, the personnel in the New Accounts departments eucourage it and create an impression that taxes and problems normally associated with probate can be avoided by holding property as joint tenants with right of survivorship. 